Universidade de São Paulo
Hospital de Reabilitação de Anomalias Craniofaciais

\title{
Potenciais Evocados Auditivos de Tronco Encefálico na Holoprosencefalia
}

Melissa Zattoni Antoneli

Área de concentração: Distúrbios da Comunicação Humana.

Bauru

2006 


\author{
Universidade de São Paulo \\ Hospital de Reabilitação de Anomalias Craniofaciais
}

\title{
Potenciais Evocados Auditivos de Tronco Encefálico na Holoprosencefalia
}

\section{Melissa Zattoni Antoneli}

Orientador: Prof. Dr. Neivo Luiz Zorzetto

Dissertação apresentada ao Hospital de Anomalias Craniofaciais da Universidade de São Paulo, para a obtenção do título de MESTRE em Ciências da Reabilitação. Área de concentração: Distúrbios da Comunicação Humana.

Bauru 


\section{UNIVERSIDADE DE SÃO PAULO}

\section{HOSPITAL DE REABILITAÇÃO DE ANOMALIAS CRANIOFACIAIS}

Rua Sílvio Marchione, 3-20

Caixa Postal: 1501

17012-900 - Bauru/SP - Brasil

Telefone: (14) 3235-8000

Profa. Dra. Suely Vilela - Reitora da USP

Prof. Dr. José Alberto de Souza Freitas - Superintendente do HRAC-USP

Autorizo, exclusivamente, para fins acadêmicos e científicos, a reprodução total ou parcial deste trabalho.

Melissa Zattoni Antoneli

Bauru, de de 2006 .

\section{ANTONELI, MELISSA ZATTONI}

A86p Potenciais Evocados Auditivos de Tronco Encefálico na Holoprosencefalia./ Melissa Zattoni Antoneli. Bauru, 2006. 108 f.: il.; $30 \mathrm{~cm}$.

Dissertação de Mestrado - Área de concentração: Distúrbios da Comunicação Humana - HRAC/USP

Orientador: Prof. Dr. Neivo Luiz Zorzetto Descritores: 1. Holoprosencefalia 2. Potenciais Evocados Auditivos 3.Tronco Encefálico 4. Vias Auditivas. 


\title{
FOLHA DE APROVAÇÃO
}

\author{
Dissertação apresentada e defendida por
}

\section{Melissa Zattoni Antoneli}

e aprovada pela comissão julgadora em

Prof.(a) Dr.(a)

Instituição

Prof.(a) Dr.(a)

Instituição

Prof.(a) Dr.(a)

Instituição (Orientador)

Prof.(a) Dr.(a)

Presidente da Comissão de Pós-Graduação do HRAC/USP

Data de depósito da dissertação junto à SPG: 
Melissa Zattoni Antoneli

03 de novembro de $1981 \quad$ Nascimento

Bauru-SP

$1999-2002$

Curso de Fonoaudiologia - Faculdade de Odontologia

de Bauru, Universidade de São Paulo (USP)

$2003-2004$

Curso de Aprimoramento Profissional / FUNDAP -

Hospital de Reabilitação de Anomalias Craniofaciais USP.

$2004-2006$

Curso de Pós-graduação em Ciências da Reabilitação, Área de Concentração Distúrbios da Comunicação Humana, Nível Mestrado. Hospital de Reabilitação de Anomalias Craniofaciais - USP. 
"Lança o teu pão sobre as águas, porque depois de muitos dias o acharás.

Reparte com sete, e ainda até com oito, porque não sabes que mal haverá sobre a terra.

Estando as nuvens cheias, derramam a chuva sobre a terra, e caindo a árvore para o sul, ou para o norte, no lugar em que a árvore cair ali ficará. Quem observa o vento, nunca semeará, e o que olha para as nuvens nunca segará. Assim como tu não sabes qual o caminho do vento, nem como se formam os ossos no ventre da que está grávida, assim também não sabes as obras de Deus, que faz todas as cousas.

Pela manhã semeia a tua semente, e à tarde não a retires a tua mão, porque tu não sabes qual prosperará: se esta, se aquela, ou se ambas igualmente serão boas. Verdadeiramente suave é a luz, e agradável é aos olhos ver o sol." 


\section{DEDICATÓRIA}

Dedico este trabalho às pessoas mais importantes da minha vida e responsáveis pela existência dela, meus queridos pais...

... Que me proporcionaram a oportunidade preciosa de ter nascido em um lar cheio de amor;

Que me criaram segundo os preceitos de Deus;

Que me deram forças na jornada que me trouxe até aqui;

Que tiveram muita paciência comigo nos momentos mais difíceis;

Que me deram amor incondicional, carinho, compreensão, incentivo e palavras de sabedoria sempre que precisei.

Os agradeço, ainda, por tudo aquilo que simples palavras não são capazes de expressar. A eles, todo o meu amor e gratidão.

Aos meus pais,

LUIZ CARLOS \& MAGALY,

dedico este estudo.

“O temor do Senhor é o princípio da ciência: os loucos desprezam a sabedoria e a instrução. Filho meu, ouve a instrução de teu pai, e não deixes a doutrina de tua mãe. Porque diadema de graça serão para a tua cabeça, e colares para o teu pescoço."

Provérbios de Salomão, 1: 7-9 


\section{AGRADECIMENTOS ESPECIAIS}

A Deus que, por infinita bondade, me concedeu a dádiva da Vida, e como presentes especiais, uma profissão, grandes amigos, saúde, felicidade, paz, e o maior presente que eu poderia querer mas não saberia escolher tão bem quanto Ele: minha família maravilhosa e minha religião, que são a minha base.

Ao meu querido "chefe", Dr. Richieri, que abraçou este trabalho e me deu a oportunidade maravilhosa de conviver diariamente com uma das pessoas que mais admiro. Agradeço infinitamente pelo privilégio de ter seu nome em meus trabalhos, de tê-lo tido como chefe do setor onde desenvolvi esse trabalho, de sempre ter aprendido com ele muito mais do que eu esperava.

À minha pequena grande amiga, $\mathbf{D r}^{\mathrm{a}}$ Lucilene Arilho Ribeiro, por ter idealizado a pesquisa com Holoprosencefalia, tornando impossível não dizer que, sem sua dedicação, esse trabalho não existiria. Muito mais que isso, devo agradecê-la pelas horas intermináveis de conversa, das quais sobrevinham ora lágrimas ora boas risadas. Por detrás dessa face meiga e desse porte delicado, esconde-se uma pessoa forte, determinada e equilibrada; por isso devo dizer que é um privilégio tê-la como amiga e ter desfrutado de sua companhia numa fase que tanto necessitei. Ela trouxe, além de valiosos conhecimentos, muita alegria e união ao nosso ambiente de trabalho, tornando a realização desse estudo não só mais fácil como muito mais prazerosa. 
À minha querida e eterna professora, Dr $^{\mathrm{a}}$ Kátia Alvarenga, que foi a responsável pela minha formação em Audiologia durante a graduação e orientou minha primeira pesquisa em eletrofisiologia, me transmitindo a dose certa de cada uma das qualidades necessárias a um audiologista e a um pesquisador, tornando-se meu exemplo, minha referência. Mais do que conhecimento, me transmitiu o amor pela Audiologia, influenciando na escolha da linha de pesquisa que escolhi seguir. Pessoa muito importante, exerceu um papel decisivo na minha vida profissional e hoje eu posso colher os frutos da árvore que ela semeou.

A eles, meus grandes MESTRES,

\section{Minha eterna GRATIDÃO, ADMIRAÇÃO e RESPEITO.}

"Bem-aventurado o homem que acha sabedoria e o homem que adquire conhecimento.

Aumento de dias há na sua mão direita, na sua esquerda riquezas e honra.

Os seus caminhos são caminhos de delícias, e todas as suas veredas, paz." 


\section{AGRADECIMENTOS}

À Prof ${ }^{\mathrm{a}}$ Dr $^{\mathrm{a}}$ Inge Elly Kiemle Trindade, presidente da comissão de pósgraduação do HRAC-USP, pelo exemplo de espírito científico, pelo constante incentivo e pela determinação com que dirige nossos cursos.

Ao Prof. Dr. Neivo Luiz Zorzetto, meu orientador, pessoa fantástica com quem tive o privilégio de conviver desde meu primeiro ano de faculdade. Agradeço infinitamente por me auxiliar a conduzir esse estudo com tanta sabedoria.

À Prof ${ }^{\mathrm{a}}$ Dr $^{\mathrm{a}}$ Sthella Zanchetta, profissional que, apesar de tantos compromissos, passou horas discutindo os resultados, contribuindo de forma valiosa com esse estudo. Mesmo ao sugerir grandes mudanças ou correções, manteve seu jeito doce que me transmitiu toda a serenidade necessária para continuar.

À Prof ${ }^{\mathrm{a}}$ Dr $^{\mathrm{a}}$ Simone Aparecida Capellini, que dispendeu momentos preciosos, inclusive de seus finais de semana, para me auxiliar na elaboração dessa dissertação. Seu pulso firme e seu jeito sempre alegre me renovaram as idéias e me incentivaram grandemente.

Ao meu irmão Rafael, pessoa que tanto amo, pela paciência comigo especialmente na fase final deste trabalho, durante a qual o nosso computador foi só meu, assim como todas as outras prioridades lá em casa.

À minha amiga e colega de mestrado Giselda, pelo companheirismo, pelas discussões e trocas de experiências relativas às nossas dissertações, que nasceram e cresceram juntas e hoje se completam.

Ao pessoal do Setor de Genética, Cida, Daniela Ruiz, Tatiana Cassab e Carlos Bettoni pela solicitude com que sempre me auxiliaram, pela paciência e pelo carinho. 
À minha amiga Cláudia Danielli, que não hesitou em colaborar com sua própria imagem para ilustração dessa dissertação e, com toda a sua doçura, tornou meus dias muito mais felizes. Agradeço pelo companheirismo e pela convivência com alguém que tem o dom de tornar tudo mais fácil.

À minha amiga Priscila, pela ajuda espiritual, pelos nossos almoços e conversas, que me proporcionaram a calma necessária à fase final de elaboração deste estudo.

Aos amigos do CPD, Jorge, Rinaldo, Marcos, Luiz Otávio e Carlos Frederico pelo pronto auxílio com relação ao equipamento utilizado durante esse estudo e pela importante ajuda na parte de informática.

Às amigas do Setor de Fonoaudiologia, pelo suporte durante a fase de coleta de dados, quando houve necessidade de confirmar alguns resultados.

Ao Prof. Dr. José Roberto Pereira Lauris pela análise estatística desse estudo e pela paciência comigo, sempre tirando todas as dúvidas.

Aos amigos da Secretaria de Pós-Graduação, Andréia, Rogério, Saulo e Zezé, pelo respaldo necessário durante todo o meu caminho dentro do curso de mestrado, pelo pronto auxílio e pelas palavras amigas.

Às amigas da pós-graduação, Luciane Riehl, Carolina Brustello, Janete Galante, Mônica Lopes, Giane Ernestino, Trixy Niemeyer e Adriana Gomes pelo companheirismo e alegria constantes durante nosso período de aulas e encontros no laboratório de informática.

À querida e inestimável X Turma de Fonoaudiologia da FOB-USP, minha turma de faculdade, por ter feito parte de um período tão importante da minha vida, a graduação, de forma tão especial e marcante. 
Aos pacientes e seus pais, que colaboraram de forma tão rica e espontânea com este estudo, especialmente pelas horas gastas na tentativa de concluir os exames. Alguns pais, mesmo diante de um prognóstico desolador e conscientes de que pouco poderia ser feito por seus filhos, empenharam-se em colaborar com o crescimento da ciência. Essa participação foi muito valiosa.

À CAPES - Coordenação de Aperfeiçoamento de Pessoal de Nível Superior, pelo apoio financeiro durante a realização deste estudo.

Muito Obrigada! 


\section{SUMÁRIO}

LISTA DE ABREVIATURAS ............................................................ xviii

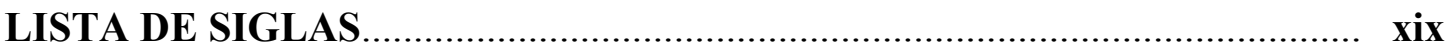

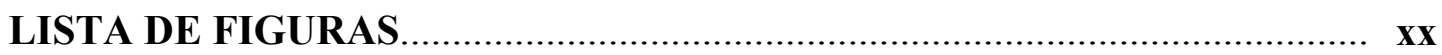

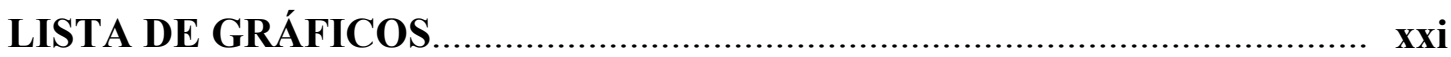

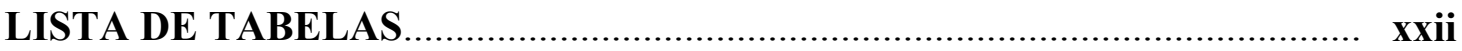

RESUMO

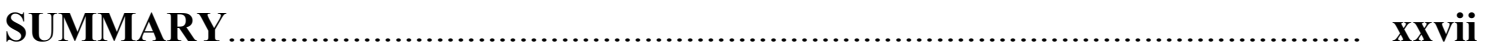

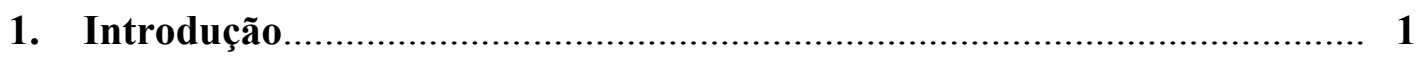

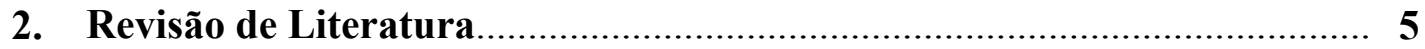

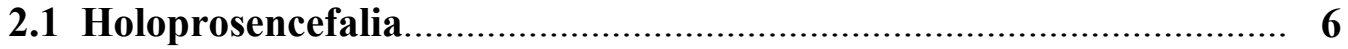

2.1.1 Definição.............................................................................. 6

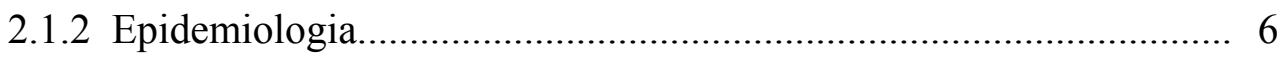

2.1.3 Diagnóstico e Prognóstico........................................................... 7

2.1.4 Embriologia....................................................................... 10

2.1.5 Classificação..................................................................... 12

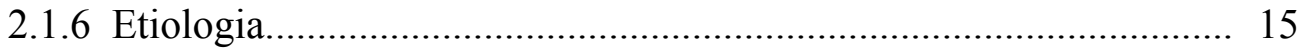

2.1.7 Aspectos moleculares............................................................. 17

2.2 Potenciais Evocados Auditivos de Tronco Encefálico (PEATE)......... 20

2.2.1 Estruturas geradoras do PEATE.................................................. 21

2.2.2 Síntese da anatomofisiologia das vias auditivas............................ 21

2.2.3 Registro do PEATE................................................................... 24

2.2.4 Parâmetros de análise do PEATE.................................................... 26

2.2.5 Valores de latência do PEATE....................................................... 28

2.2.6 Características do estímulo e parâmetros mais utilizados................ 29

2.3 Estudos Audiológicos e HPE.................................................................. 32 


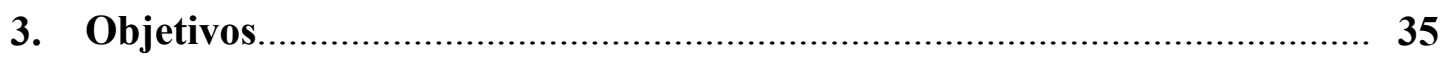

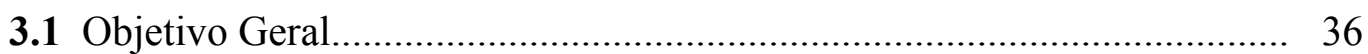

3.2 Objetivos Específicos...................................................................... 36



4.1 Seleção da casuística........................................................................ 38

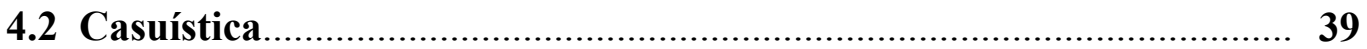

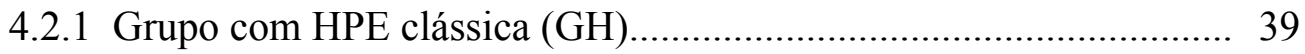

4.2.2 Grupo com HPE-like (GHL) .................................................... 39

4.2.3 Grupo Controle (GC)............................................................ 39

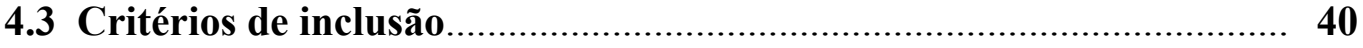

4.4 Critérios de exclusão...................................................................... 41

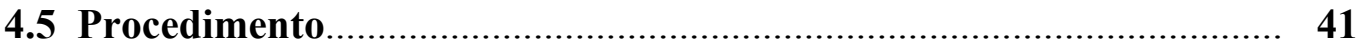

4.5.1 FASE 1- Calibração biológica do equipamento............................. 42

4.5.2 FASE 2 - Coleta de dados.......................................................... 42

4.5.2.1 Avaliação audiológica...................................................... 42

4.5.2.2 Avaliações complementares............................................... 47

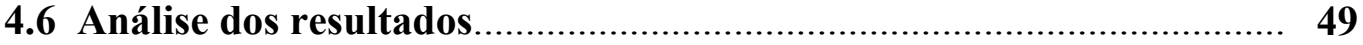

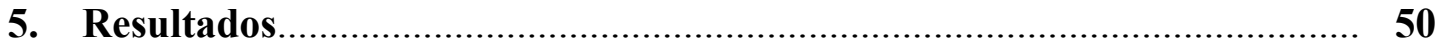

5.1 FASE 1: Definição do padrão de normalidade do PEATE.................. 51

5.2 FASE 2: Resultados do PEATE nos grupos estudados....................... 52

5.2.1 Caracterização dos grupos.......................................................... 52

5.2.2 Procedimentos prévios............................................................. 56

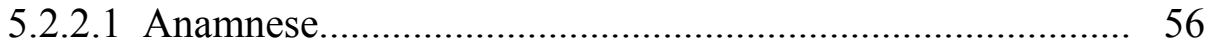

5.2.2.2 Audiometria.................................................................. 58

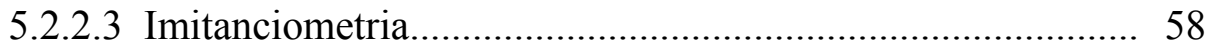



5.2.3.1 Descrição dos resultados referentes ao GC.......................... 61

5.2.3.2 Descrição dos resultados referentes ao GH........................ 62 


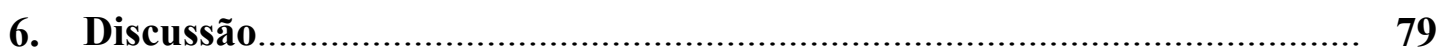

6.1 Considerações sobre a calibração biológica...................................... 80

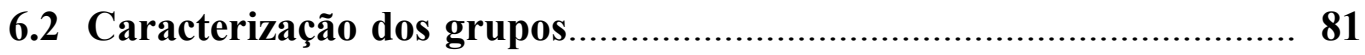

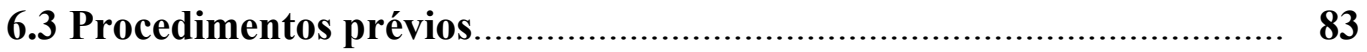

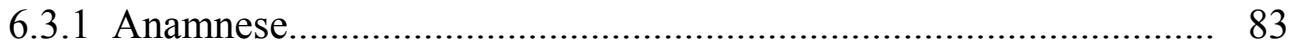

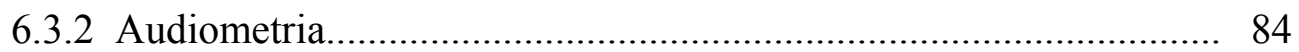

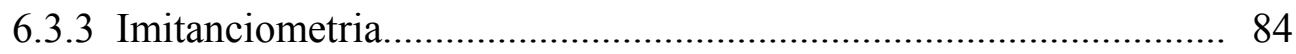

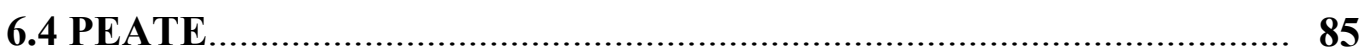

6.4.1 Grupo Controle (GC)............................................................ 85

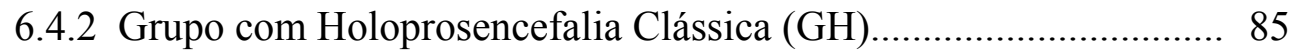

6.4.3 Grupo com Holoprosencefalia-like (GHL)................................. 87

6.4.4 Considerações sobre o PEATE nos grupos experimentais.............. 87

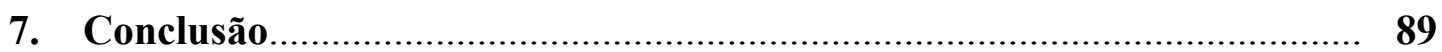

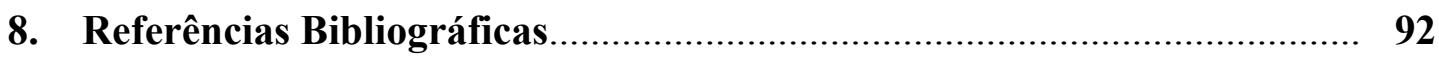

ANEXOS 


\section{LISTA DE ABREVIATURAS}

HPE Holoprosencefalia

HPE-like Holoprosencefalia-like

AL Alobar (subtipo de HPE)

SL Semilobar (subtipo de HPE)

L Lobar (subtipo de HPE)

OD Orelha direita

OE Orelha esquerda

V i.a. Diferença interaural da onda $\mathrm{V}$

g.l. Graus de liberdade

N Número

GH ou H Grupo com Holoprosencefalia Clássica

GHL ou HL Grupo com Holoprosencefalia-like

GC ou C Grupo Controle 


\section{LISTA DE SIGLAS}

USP Universidade de São Paulo

ECLAMC Estudo colaborativo latino-americano das malformações congênitas

HRAC Hospital de Reabilitação de Anomalias Craniofaciais

UEP Unidade de Ensino e Pesquisa (Unidade do HRAC)

CPD Centro de Processamento de Dados (Unidade do HRAC)

CEP Comitê de Ética em Pesquisa - HRAC

VEP Potenciais Evocados Visuais (Visual Evoked Potentials)

ABR Potenciais Evocados Auditivos (Auditory Brainstem Response)

PEATE Potenciais Evocados Auditivos de Tronco Encefálico

ATL Audiometria Tonal Liminar

IRF Índice Percentual de Reconhecimento de Fala

SRT Limiar de Recepção da Fala (Speech Reception Threshold)

DP Desvio-padrão

$\mathbf{X}^{2} \quad$ Qui-quadrado

p Nível de significância

ms Milissegundos

ml Mililitros

daPa Decapascal

dB Decibel

dBnHL Decibel nível de audição (dBNA) 
dBSPL Decibel nível de pressão sonora (dBNPS)

(k) $\mathbf{H z} \quad$ (kilo) Hertz

\section{LISTA DE FIGURAS}

Figura 1. Exame ultrassonográfico mostrando HPE em feto (Arquivo do Hospital Universitário de Getafe, Madrid, usada seguindo as formalidades éticas e com as devidas permissões)

Figura 2. Desenvolvimento embrionário do cérebro humano (modificado de Moore e Persaud 1998)

Figura 3. Classificação dos tipos de HPE quanto à severidade das malformações faciais. 1) Sinoftalmia, 2) Etmocefalia, 3) Cebocefalia, 4) Agenesia de pré-maxila e 5) Malformações faciais leves, como hipotelorismo ocular e ponte nasal baixa. Fotos de pacientes registrados no ECLAMC (1), National Institutes of Health (2) e no Hospital de Reabilitações de Anomalias Craniofaciais (3; $4 \mathrm{ab} ; 5 \mathrm{ab}$ ), usadas seguindo as formalidades éticas e com as devidas permissões

Figura 4. Esquema ilustrativo das vias auditivas centrais (Katz 1999).....

Figura 5. Morfologia normal de ondas do PEATE, seguido pelos traçados vistos em perdas condutivas, sensorioneurais e neurais, respectivamente (Hall e Mueller, 1997)

Figura 6. Posição do paciente adotada para o registro do PEATE

Figura 7. Equipamento utilizado, sala acusticamente tratada e maca para acomodação do paciente durante a aquisição dos PEATE.

Figura 8. Exemplos de traçados do PEATE obtidos em pacientes dos grupos H e HL mostrando: (a) exame com latências, morfologia e reprodutibilidade de ondas normais; (b) exame alterado com atraso 
de latências e ausência de ondas e (c) exame severamente alterado, apresentando ondas de pobre morfologia e reprodutibilidade.

\section{LISTA DE GRÁFICOS}

Gráfico 1. Comparação das médias etárias, em meses, nos grupos GH (HPE clássica), GHL (HPE-like) e GC (controle).

Gráfico 2. Distribuição dos indivíduos dos grupos H, HL e C quanto ao gênero.

Gráfico 3. Distribuição dos indivíduos do GH quanto ao tipo de HPE.

Gráfico 4. Distribuição dos indivíduos do GH e do GHL quanto às mutações.

Gráfico 5. Distribuição dos indivíduos dos grupos H e HL quanto aos dados da anamnese (presença de queixa auditiva).

Gráfico 6. Tipo de curva timpanométrica encontrada nas orelhas dos pacientes dos grupos $\mathrm{H}$, HL e C

Gráfico 7. Resultados da pesquisa do reflexo acústico nos grupos H, HL e C.

Gráfico 8. Classificação dos resultados do PEATE no GH.

Gráfico 9. Resultados da análise das latências absolutas das ondas I, III e V e interpicos I-V, III-V e I-III do PEATE no GH.

Gráfico 10. Resultados da análise das latências absolutas das ondas I, III e V do PEATE no GHL 


\section{LISTA DE TABELAS}

Tabela 1. Distribuição dos indivíduos estudados quanto ao gênero e idade.

Tabela 2. Valores mínimos e máximos obtidos pelas médias e desviospadrão das latências dos indivíduos normais, para os gêneros feminino e masculino.

Tabela 3. Valores mínimos, máximos, médias e desvios-padrão das latências absolutas e interpicos, por orelha, no GC, considerando $\mathrm{n}=22$.

Tabela 4. Distribuição dos valores mínimos, máximos, médios e desviospadrão do GH e as médias e desvios-padrão das latências absolutas e interpicos do GC, por orelha.

Tabela 5. Comparação da análise da latência absoluta da onda I entre GH e GC por meio do teste do Qui-quadrado.

Tabela 6. Comparação da análise da latência absoluta da onda III entre GH e GC por meio do teste do Qui-quadrado.

Tabela 7. Comparação da análise da latência absoluta da onda V entre GH e GC por meio do teste do Qui-quadrado.

Tabela 8. Comparação da análise da latência interpicos I-V entre GH e GC 
por meio do teste do Qui-quadrado

Tabela 9. Comparação da análise da latência interpicos III-V entre GH e GC por meio do teste do Qui-quadrado.

Tabela 10. Comparação da análise da latência interpicos I-III entre GH e GC por meio do teste do Qui-quadrado.

Tabela 11. Comparação da análise da latência absoluta da onda I entre GH e GHL por meio do teste do Qui-quadrado.

Tabela 12. Comparação da análise da latência absoluta da onda III entre GH e GHL por meio do teste do Qui-quadrado

Tabela 13. Comparação da análise da latência absoluta da onda V entre GH e GHL por meio do teste do Qui-quadrado.

Tabela 14. Comparação da análise da latência interpicos I-V entre GH e GHL por meio do teste do Qui-quadrado.

Tabela 15. Comparação da análise da latência interpicos III-V entre GH e GHL por meio do teste do Qui-quadrado

Tabela 16. Comparação da análise da latência interpicos I-III entre GH e GHL por meio do teste do Qui-quadrado.

Tabela 17. Distribuição dos valores mínimos, máximos, médios e desviospadrão do GHL e as médias e desvios-padrão das latências absolutas e interpicos do GC, por orelha.

Tabela 18. Comparação da análise da latência absoluta da onda I entre GHL e GC por meio do teste do Qui-quadrado. 
Tabela 19. Comparação da análise da latência absoluta da onda III entre GHL e GC por meio do teste do Qui-quadrado.

Tabela 20. Comparação da análise da latência absoluta da onda V entre GHL e GC por meio do teste do Qui-quadrado

Tabela 21. Apresentação dos p-value obtidos no estudo estatístico, comparando os valores de latências dos três grupos estudados, por meio do teste ANOVA

Tabela 22. Médias e desvios-padrão (DP) dos valores obtidos no três grupos para cada variável estudada e resultado do Teste de Tukey, considerando $\mathrm{p}=0,05$.

Tabela 23. Distribuição das médias e desvios-padrão (DP) do GH+GHL e do GC e significância (p) da diferença das latências do PEATE segundo o teste $t$ de Student. 


\section{RESUMO}

ANTONELI, MZ. Potenciais Evocados Auditivos de Tronco Encefálico na Holoprosencefalia [dissertação].

Bauru: Hospital de Reabilitação de Anomalias Craniofaciais, Universidade de São Paulo; 2006.

Objetivo: Avaliar e comparar os achados dos Potenciais Evocados Auditivos de Tronco Encefálico em indivíduos com holoprosencefalia (HPE) e holoprosencefalia-like (HPElike).

Modelo: Análise prospectiva comparando os achados dos PEATE entre três grupos: indivíduos com HPE clássica $(\mathrm{GH})$, indivíduos com HPE-like (GHL) e grupo controle (GC), a um nível de significância de 5\%.

Local de Execução: Setor de Genética, HRAC-USP.

Participantes: 57 pacientes, com idades entre 1 ano e 6 meses e 22 anos, sendo 13 com HPE clássica, 22 com HPE-like, e um grupo controle de 22 indivíduos normais.

Variáveis: Latências absolutas das ondas I, III e V; latências interpicos I-V, III-V e I-III e diferença interaural da onda $\mathrm{V}$ do PEATE, em milissegundos, para cada orelha.

Resultados: Os valores médios em milissegundos das latências absolutas e interpicos nas orelhas direita e esquerda respectivamente foram os seguintes. Para a onda I: 2,21 e 2,19 (GH); 1,99 e 2,01 (GHL); 1,92 e 1,91 (GC). Para a onda III: 4,35 e 4,52 (GH); 4,04 e 4,04 (GHL); 3,97 e 3,94 (GC). Para a onda V: 6,47 e 6,51 (GH); 5,95 e 5,94 (GHL); 5,90 e 5,90 (GC). Para o interpicos I-V: 4,20 e 4,24 (GH); 3,94 e 3,92 (GHL); 3,97 e 3,97 (GC). Para o interpicos III-V: 2,27 e 2,07 (GH); 1,91 e 1,90 (GHL); 1,92 e 1,95 (GC). Para o interpicos I-III: 2,14 e 2,33 (GH); 1,03 e 2,01 (GHL); 2,04 e 2,01 (GC). Os valores de diferença interaural da onda $\mathrm{V}$ foram: 0,13 (GH); 0,06 (GHL) e 0,03 (GC). Conclusões: Os dados sugerem que grande parte dos indivíduos com HPE clássica apresentam alterações de PEATE compatíveis com o grau de comprometimento neurológico, enquanto aqueles com HPE-like apresentam poucas alterações, sendo estas justificadas pelas patologias de orelha média decorrentes da fissura de palato.

Descritores: Holoprosencefalia, Potenciais Evocados Auditivos, Tronco Encefálico,Vias Auditivas. 


\section{SUMMARY}

ANTONELI, MZ. Auditory Brainstem Response in Holoprosencephaly [dissertação]. Bauru: Hospital de Reabilitação de Anomalias Craniofaciais, Universidade de São Paulo; 2006.

Objective: To evaluate and compare Auditory Brainstem Response (ABR) findings in patients with holoprosencephaly (HPE) and the "HPE-like" phenotype.

Model: A prospective analysis comparing ABR results among three different groups: patients with classic HPE (GH), patients with HPE-like (GHL) and control group (GC), at a $5 \%$ significance level.

Setting: Genetics Department, HRAC-USP.

Participants: 57 patients, aged from 18 months to 22 years. Thirteen of them had classic HPE, 22 had HPE-like, and 22 were audiologically normal individuals, who joined the GC.

Variables: Waves I, III and V absolute latencies; interpeak intervals I-V, III-V and I-III and wave $\mathrm{V}$ interear difference of $\mathrm{ABR}$, in milisseconds, considering both right and left ears.

Results: Mean values, in milisseconds, of absolute latencies and interpeaks recorded from right and left ears, respectivelly, were: Wave I: 2,21 and 2,19(GH); 1,99 and 2,01 (GHL); 1,92 and 1,91 (GC). Wave III: 4,35 and 4,52 (GH); 4,04 and 4,04 (GHL); 3,97 and 3,94 (GC). Wave V: 6,47 and 6,51 (GH); 5,95 and 5,94 (GHL); 5,90 and 5,90 (GC). Interpeak I-V: 4,20 and 4,24 (GH); 3,94 and 3,92 (GHL); 3,97 and 3,97 (GC). Interpeak III-V: 2,27 and 2,07 (GH); 1,91 and 1,90 (GHL); 1,92 and 1,95 (GC). Interpeak I-III: 2,14 and 2,33 (GH); 1,03 and 2,01 (GHL); 2,04 and 2,01 (GC). Wave V interear difference were: 0,13(GH); 0,06 (GHL) and 0,03 (GC).

Conclusions: Results suggest that most patients with classic HPE have abnormalities detected by ABR testing, which are related to the severity of neurologic impairment. Otherwise, those with the HPE-like phenotype have few alterations, most likely resulting from middle ear pathologies that occur in presence of cleft palate.

Key Words: Holoprosencephaly, Auditory Evoked Potentials, Brain Stem, Auditory Pathways. 


\section{INTRODUÇÃO}

A falha na clivagem do prosencéfalo tem como principal resultante a Holoprosencefalia (HPE), seqüência malformativa que pode estar acompanhada de outras anomalias estruturais medianas do sistema nervoso central e/ou da face. $\mathrm{O}$ defeito de desenvolvimento e/ou segmentação do prosencéfalo ocorre quando o telencéfalo falha em se dividir nos dois hemisférios e nos ventrículos cerebrais e o diencéfalo na formação do tálamo, hipotálamo e epitálamo. Nervos e bulbos olfatórios, corpo caloso e hipófise podem estar ausentes (Siebert et al 1990, Norman et al 1995, Golden 1998).

A HPE tem a alta incidência de 1:250 durante a embriogênese, mas devido à letalidade intra-uterina, a prevalência para nascidos vivos é de 1:16.000 (Roach et al 1955).

É uma condição etiologicamente heterogênea, pois além de mutações em diversos genes, inúmeros fatores ambientais podem causar HPE. Ming e Muenke (2002) sugerem que, nas formas mais graves, a atuação de mais de um desses fatores seria necessária.

A HPE é usualmente subdividida em três tipos: alobar, a forma mais grave; semilobar, forma intermediária; e lobar, a forma mais branda (DeMyer e Zeman 1963).

Tem-se estabelecido que crianças com HPE apresentam dificuldades significativas para alcançar qualquer progresso de desenvolvimento neuropsicomotor (Cohen et al 1990); no entanto, muitas crianças com HPE podem adquirir um número variado de habilidades, sendo capazes de ouvir, reagir a ruídos, movimentar a cabeça em direção ao som e, com o tempo, adquirem a habilidade de reconhecer algumas vozes ou sons. 
A maioria das crianças que vivem alguns meses mostram capacidade de aprender e lembrar, apresentando, por exemplo, respostas consistentes a sons e vozes particulares.

Roessler et al (2003) chamaram atenção para um fenótipo distinto dentro do espectro holoprosencefálico, denominado de holoprosencefalia-like (HPE-like), que inclui casos de hipotelorismo isolado, incisivo central maxilar único, fissura mediana de lábio e/ou palato atípica, comprometimento parcial da pré-maxila e hipoplasia da porção média da face, porém até o presente não existe uma definição padronizada desse fenótipo. Indivíduos com HPE-like usualmente apresentam desenvolvimento neuropsicomotor e cognitivo normal, no entanto, alterações da linguagem podem ocorrer em boa parte destes indivíduos (Santiago et al 2006).

Sabe-se que, quando a integridade das vias auditivas em suas porções periférica e/ou central está comprometida, alterações auditivas podem interferir diretamente no processamento dos estímulos acústicos e conseqüentemente no desenvolvimento da linguagem e do aprendizado, pois ela constitui um pré-requisito para a aquisição e desenvolvimento normal de tais habilidades. Por esta razão, crianças consideradas de risco devem ser submetidas à avaliação audiológica para que possíveis alterações possam ser identificadas e minimizadas. Nesse contexto, a investigação do sistema auditivo em indivíduos com HPE, especialmente aqueles com o fenótipo like, faz-se de extrema importância para melhor delineamento do quadro e definição das estratégias de tratamento.

Existem variados testes subjetivos e objetivos utilizados na rotina clínica audiológica. Dentre eles, o método objetivo mais difundido e utilizado atualmente é a pesquisa dos Potenciais Evocados Auditivos de Tronco Encefálico (PEATE), especialmente por fornecer valiosas informações a respeito das vias auditivas de forma 
não invasiva. Os PEATE assumiram um papel fundamental na prática da audiologia clínica por auxiliar tanto no diagnóstico audiológico quanto neurológico.

Os PEATE ou potenciais de curta latência são gerados pela ativação seqüencial e sincrônica das fibras nervosas ao longo da via auditiva. Essa resposta depende e reflete a sensitividade auditiva periférica (orelhas média e interna) e a integridade neural do oitavo nervo craniano e tronco encefálico.

Devido ao prognóstico fechado que existe quanto ao desenvolvimento global de crianças com HPE, pouca ou nenhuma ênfase tem sido dada a trabalhos que estudam funções relacionadas à linguagem, audição e cognição neste tipo de anomalia e isto ocorre também na forma like, impondo a esses pacientes um estigma impróprio.

Tendo em vista a importância da audição para o adequado processo de aquisição e desenvolvimento da linguagem e a escassez de estudos nacionais e internacionais que investiguem o sistema auditivo em indivíduos com HPE, este estudo pretende determinar a condição da condução neuronal desde o VIII par craniano em sua porção distal até o complexo olivar superior, no nível do tronco encefálico. 


\section{REVISÃO DE LITERATURA}

\subsection{HOLOPROSENCEFALIA}

\subsubsection{Definição}

O termo Holoprosencefalia foi proposto por DeMyer e Zeman (1964) para a caracterização do envolvimento de ambos os componentes do prosencéfalo: o telencéfalo e o diencéfalo.

Diferentes graus de comprometimento facial têm sido observados em pacientes com HPE. As anomalias faciais podem ser graves, incluindo casos de ciclopia, probóscide, narina única e agenesia de pré-maxila, sendo estes defeitos usualmente associados a malformações cerebrais mais graves. Podem ocorrer manifestações faciais menos graves, tais como: dente incisivo maxilar central único, coloboma ocular, hipotelorismo ocular, anosmia, fissura labiopalatina e microcefalia (DeMyer et al 1964, Cohen 1989b). Quando não há malformação cerebral, as manifestações faciais leves são denominadas "microssinais" ou "microformas" e têm sido reconhecidas como predisponentes ao nascimento de crianças com HPE nas gerações seguintes (Berry et al 1984, Hattori et al 1987, Fryns e Van den Berghe 1988, Jaramillo et al 1988).

\subsubsection{Epidemiologia}

A HPE é considerada a malformação cerebral mais comum em humanos. Matsunaga e Shiota (1977) realizaram um estudo no Japão que identificou, dentre 36.380 conceptos obtidos através de aborto induzido, 150 embriões com HPE, no 
período de 1968 a 1974, indicando a alta prevalência de um em 250 embriões. Neste estudo, aproximadamente $50 \%$ das mães dos embriões malformados tiveram algum problema durante a gestação, sendo esses casos considerados pelos obstetras como de alta probabilidade para aborto espontâneo. Assim sendo, a maior parte dos embriões com HPE tendem a ser abortados espontaneamente (Matsunaga e Shiota 1977, Shiota 1993). Yamada et al (2004) descreveram uma prevalência ainda maior de HPE durante o período embrionário, resultante de um estudo epidemiológico envolvendo 44.000 embriões, dos quais 221 apresentavam HPE, ou seja, um caso a cada 200 embriões. Em concordância com a alta taxa de mortalidade intra-uterina, a prevalência de HPE em nascidos vivos é baixa, da ordem de 1 em 16.000 (Roach et al 1975). Um total de 121 casos de HPE foi identificado entre 1.035.386 nascidos vivos e natimortos em estudo realizado na Califórnia, utilizando dados de um registro de defeitos congênitos da população, correspondendo a uma prevalência de 1,2 em 10.000 nascimentos (Croen et al 1996). Em outro estudo realizado na América do Sul, 57 casos de HPE foram identificados em um total de 244.511 nascidos vivos, representando um em cada 4.300 (Orioli et al 2001).

\subsubsection{Diagnóstico e Prognóstico}

O diagnóstico pré-natal tem sido mais eficaz por meio da ultrassonografia de melhor qualidade e realizada com maior freqüência (Aubry et al 1981, Hill et al 1982, Le Marec et al 1984, Pretorius et al 1986, Parant et al 1997). Em casos familiais e outros nos quais a ultrassonografia indicou alterações, o uso de ressonância magnética fetal tem auxiliado no diagnóstico final dos embriões afetados e na decisão da família pela continuidade ou término da gestação em países onde o aborto é legalmente 
permitido (Toma et al 1990, Sonigo et al 1998, Sharma et al 2003). Na Figura 1 podemos observar ultrassonografia de feto evidenciando a formação de um único ventrículo e a fusão talâmica, compatíveis com o quadro de HPE.



Figura 1 - Exame ultrassonográfico mostrando HPE em feto (Arquivo do Hospital Universitário de Getafe, Madrid, usada seguindo as formalidades éticas e com as devidas permissões).

O nascimento de uma criança com HPE gera muitas perguntas em relação ao tempo de sobrevivência e à qualidade de vida. Muitas vezes, a orientação recebida dos médicos é que a criança irá morrer em poucos dias ou semanas após o nascimento. Em pesquisa realizada com 62 casos de HPE alobar, o tempo de sobrevivência se mostrou mais associado ao grau de funcionalidade do cérebro do que à sua configuração anatômica demonstrada por tomografia ou ressonância magnética (Barr e Cohen 1999). Além disso, foi observado que crianças com alterações faciais muito graves, como a ciclopia, certamente morrem até uma semana após o nascimento, assim como $50 \%$ dos portadores de HPE alobar com agenesia de pré-maxila, fissura labial uni ou bilateral ou anomalias faciais mais leves podem morrer em 4-5 meses e $20-30 \%$ sobrevivem por pelo menos um ano (Barr e Cohen 1999). Outro estudo mais recente descreveu indivíduos com HPE semilobar e lobar com aproximadamente 18 anos de idade, 
demonstrando uma grande variação no tempo de sobrevivência destes pacientes (Stashinko et al 2004). Assim, os estudiosos em HPE sugerem que o prognóstico de sobrevivência seja cauteloso e jamais definitivo (Barr e Cohen 1999).

O desenvolvimento de habilidades motoras é usualmente muito deficiente. Algumas crianças desenvolvem a habilidade de acompanhar objetos colocados em sua frente e, por vezes, tocá-los. Poucas conseguem trazer suas mãos à linha média para colocá-las na boca ou para segurar a mamadeira. O controle cervical também é normalmente deficiente.

Praticamente todas as crianças com HPE alobar e muitas com HPE semilobar mostram evidência de disfunção do tronco encefálico. O padrão respiratório pode ser irregular, com períodos alternados de respiração rápida e lenta, longas pausas entre as respirações ou completa irregularidade respiratória. Assim como o padrão respiratório, o ritmo e freqüência cardíacos são normalmente irregulares. Algumas crianças também apresentam dificuldade de deglutição, engasgando ou vomitando comida e, às vezes, sua própria saliva. O controle da temperatura também é usualmente inadequado (Barr e Cohen 1999).

A deficiência do hormônio anti-diurético (ADH) nos pacientes com HPE pode causar perda excessiva de água por meio da urina, provocando hipernatremia e diabetes insipidus (Hasegawa et al 1990, Traggiai e Stanhope 2002). Devido à deficiência do hormônio de crescimento (GH), a taxa de crescimento é baixa na maioria dos casos e, mesmo quando se apresenta normal no início, esta taxa tende a diminuir após poucos meses (Cameron et al 1999, Traggiai e Stanhope 2002). Devido à deficiência do hormônio estimulante da tireóide (TSH), estas crianças também apresentam constipação freqüente, o que representa um grave problema e requer atenção especial (Barr e Cohen 1999). 


\subsubsection{Embriologia}

O desenvolvimento craniofacial é de alta complexidade. Depende de um processo dinâmico que envolve estágios múltiplos que começam com a formação da crista neural, necessária ao desenvolvimento do sistema nervoso central, e a conseqüente migração para formar juntamente com as células mesenquimais, o primórdio facial. Atividades indutivas e sinalizadoras coordenam o crescimento do primórdio facial a partir de brotos mesenquimais indiferenciados até um intrincado mosaico de estruturas ósseas e cartilaginosas que, em conjunto com os músculos e outros tecidos, constituirão o arcabouço definitivo da face (Francis-West et al 1998).

Dentro do desenvolvimento craniofacial merece especial atenção o tipo, o timing e a localização das moléculas reguladoras que influenciam os diferentes estágios do desenvolvimento do sistema nervoso central e que incluem indução neuronal, especialização regional, migração, crescimento e orientação axonal e a formação das sinapses (Lacbawan e Muenke 2002).

Fatores genéticos ou ambientais agindo em qualquer destas etapas resultam em anormalidades cerebrais significantes que podem comprometer as vesículas cerebrais (prosencéfalo, mesencéfalo e rombencéfalo), as comissuras cerebrais (corpo caloso, comissuras anterior e posterior) e estruturas associadas (Ellison-Wright et al 2004, Thompson et al 2004).

Logo após a formação do tubo neural, três subdivisões se tornam aparentes: o prosencéfalo, o mesencéfalo e o rombencéfalo (Figura 2) (Moore e Persaud 1998). O prosencéfalo se divide em telencéfalo e diencéfalo. O telencéfalo dará origem aos hemisférios cerebrais e do diencéfalo se originarão o tálamo, o epitálamo e o hipotálamo (Moore e Persaud 1998, Carlson 1999). Na HPE existe falha do telencéfalo em dividir- 
se nos dois hemisférios cerebrais e na formação dos ventrículos laterais e do diencéfalo na formação das três estruturas dele originadas. A ausência de bulbos olfatórios (derivados do telencéfalo) ocorre com freqüência em portadores de HPE. Agenesia total ou parcial do corpo caloso e hipófise também pode ocorrer (Siebert et al 1990, Norman et al 1995, Golden 1998).

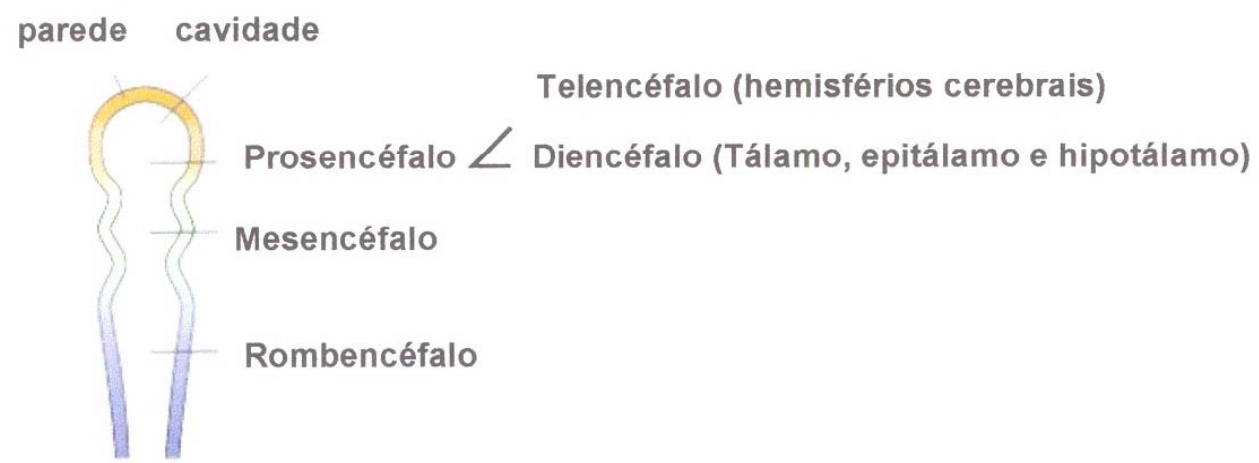

Figura 2 - Desenvolvimento embrionário do cérebro humano (modificado de Moore e Persaud 1998).

Distúrbios ocorridos nas etapas do desenvolvimento do cérebro ventral e estruturas mediais da face podem resultar em HPE. O mesoderma da placa precordal é a base da parte ventral do cérebro embrionário e pertence à linha média da placa neural (Carlson 1999). Foi demonstrado em animais que a remoção ou perda do mesoderma da placa precordal resulta em ciclopia. Assim, a placa precordal revelou ter participação essencial para a indução das estruturas do cérebro ventral e para a formação bilateral dos olhos, os quais sem a influência da placa precordal resultariam em um olho único na placa prosencefálica (Blader e Strahle 1998). No desenvolvimento normal das vesículas ópticas, estas se originam das paredes laterais, em locais separados pelo desenvolvimento das estruturas ventrais do cérebro. Em casos intermediários, a perda 
do processo frontonasal resulta em fusão parcial das estruturas laterais. Em casos graves de HPE, as estruturas ventrais do cérebro estão ausentes e o primórdio óptico conseqüentemente se desenvolve como uma evaginação única, localizado na linha média. O resultante olho cíclope na face em desenvolvimento causa o movimento anormal da estrutura nasal fusionada em direção superior ao olho único, dando origem ao cíclope com probóscide (Cooper et al 1998, Muenke e Beachy 2001).

\subsubsection{Classificação}

Segundo a classificação de DeMyer e Zeman das malformações cerebrais presentes na HPE, existem três categorias que foram definidas com base na gravidade, os tipos alobar, semilobar e lobar (DeMyer e Zeman 1963).

Na HPE alobar, forma mais grave, o cérebro é pequeno e monoventricular, sem divisão interhemisférica. O tálamo e o corpo estriado não são divididos na linha média. Os tratos e bulbos olfatórios estão sempre ausentes, assim como o corpo caloso, embora algumas fibras comissurais possam cruzar a linha média.

$\mathrm{Na}$ HPE semilobar, os lobos cerebrais são rudimentares e a fissura interhemisférica nunca é completa, estando presente apenas posteriormente, de modo que há fusão dos lobos frontais e parietais. Os bulbos e tratos olfatórios estão usualmente ausentes, mas em alguns casos eles podem ser hipoplásicos. Os corpos estriados são contínuos ao longo da linha média e o corpo caloso não é uma estrutura distinta, embora algumas fibras comissurais possam cruzar a linha média.

$\mathrm{Na}$ HPE lobar, forma menos grave, o cérebro tem lobos bem formados que podem ser de tamanho normal. Embora uma fissura interhemisférica distinta esteja presente, pode haver alguma continuidade média do giro cingulado. Os tratos e bulbos 
olfatórios podem estar ausentes, hipoplásicos ou normais. A clivagem média do tálamo e do corpo estriado pode estar incompleta (Cohen e Sulik 1992).

Foi também descrita uma variante interhemisférica da HPE, uma malformação rara, na qual os hemisférios cerebrais são bem formados frontal e occipitalmente mas falham em se dividir nas regiões parietal e frontal posterior (Barkovich e Quint 1993, Coll Masfarre et al 1998, Simon et al 2002).

A HPE pode ser vista de duas perspectivas diferentes: anatômica e genética. Quando o interesse principal é descritivo, a perspectiva anatômica é a mais adequada. Na perspectiva genética, uma definição fixa da HPE não é apropriada, pois a mesma causa pode resultar tanto na HPE quanto em microformas da mesma (Cohen Jr 2001).

Vários dismorfismos craniofaciais estão comumente associados à HPE. DeMyer et al (1964) publicaram um trabalho destacando a importância de uma série graduada de anomalias faciais na classificação da severidade da HPE, devido à expressão clínica muito variável. Embora exista uma forte correlação entre a face e o cérebro nesta condição, existem muitos exemplos nos quais a suposição de que a face prediz o cérebro não é válida, particularmente nas formas moderadas da HPE. A maioria dos pacientes com HPE possui alguma anomalia facial, mas estima-se que aproximadamente $10-20 \%$ dos indivíduos afetados com malformações cerebrais podem apresentar ausência de sinais faciais (Cohen 1989a). O inverso também pode ocorrer, ou seja, indivíduos com malformações craniofaciais incluídas no espectro da HPE associadas a desenvolvimento cerebral e inteligência normais, entretanto com risco de gerar filhos com formas mais graves de HPE (Berry et al 1984, Hattori et al 1987, Fryns e Van den Berghe 1988, Jaramillo et al 1988). 
Dentro deste espectro, sobressai uma forma clínica denominada de "Holoproslike", cujos portadores caracterizam-se por apresentar hipotelorismo associado ou não a fissuras atípicas de lábio e/ ou palato.

A classificação das características faciais proposta (DeMyer et al 1964) foi então modificada em 1989 (Cohen 1989b), dando origem aos cinco tipos baseados na expressão clínica da HPE:

1. Ciclopia: olho único ou parcialmente separado na mesma órbita (sinoftalmia), com ou sem probóscide acima do olho.

2. Etmocefalia: extremo hipotelorismo ocular e probóscide entre os olhos.

3. Cebocefalia: hipotelorismo ocular e narina única.

4. Agenesia de pré-maxila: associada a hipotelorismo ocular e nariz achatado.

5. Leve dismorfismo facial: podem estar presentes hipotelorismo ocular, coloboma de íris, ausência de ossos nasais, nariz achatado, incisivo central maxilar único, ausência de frênulo labial, fissura de lábio e/ou palato unilateral, bilateral ou mediana e hipoplasia da face média.

1.

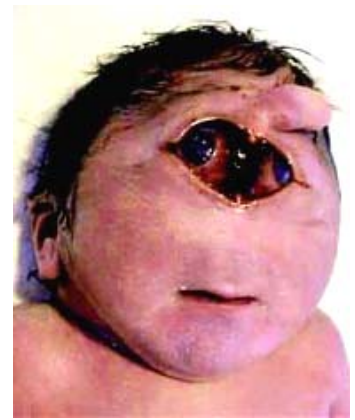

2.

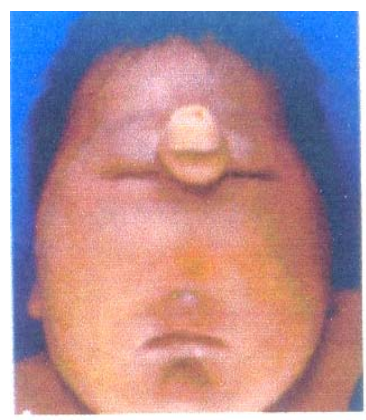

3.

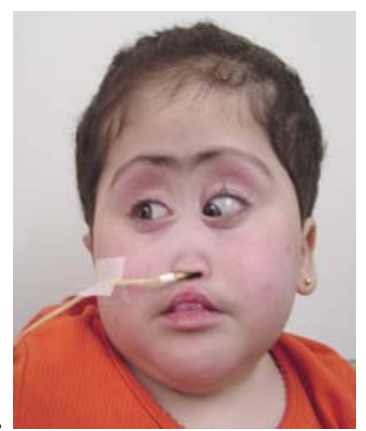



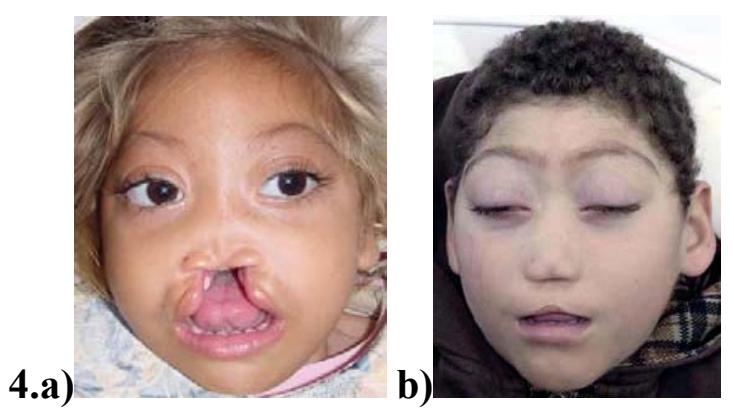

5. a)
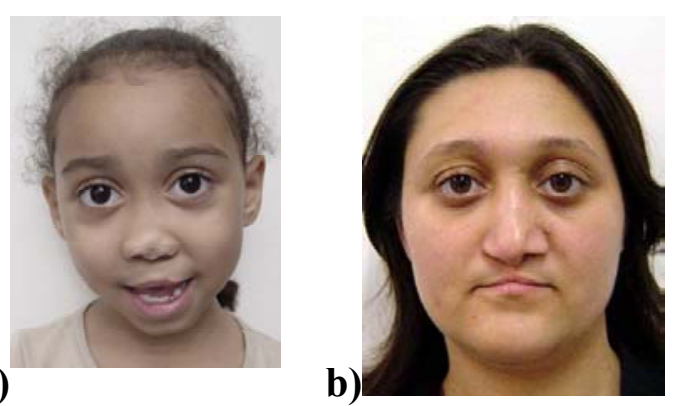

Figura 3 - Classificação dos tipos de HPE quanto à severidade das malformações faciais. 1) Sinoftalmia, 2) Etmocefalia, 3) Cebocefalia, 4) Agenesia de pré-maxila e 5) Malformações faciais leves, como hipotelorismo ocular e ponte nasal baixa. As fotos são de pacientes registrados no ECLAMC (1), National Institutes of Health (2) e no Hospital de Reabilitações de Anomalias Craniofaciais (3; 4 a, b; 5 a, b), usadas seguindo as formalidades éticas e com as devidas permissões.

\subsubsection{Etiologia}

A etiologia da HPE é extremamente heterogênea, incluindo fatores ambientais e genéticos. Existem evidências sugerindo a participação de diversos fatores ambientais como teratógenos, dentre eles o etanol, ácido retinóico, diabetes materna, infecção por citomegalovírus, salicilatos, anticonvulsivantes, sulfassalazina e hipercolesterolemia materna (Lammer et al 1985, Byrne et al 1987, Ronen e Andrews 1991, Ronen 1992, Kotzot et al 1993, Martinez-Frias 1994, Rosa 1995, Kelley et al 1996, Koyama et al 1996, Martinez-Frias et al 1998, Sezgin et al 2002). Até o momento, o único fator ambiental com estabelecido risco epidemiológico aumentado para HPE é a diabetes materna, sendo o risco aproximado para filhos de mães diabéticas de aproximadamente 
$1 \%$, ou seja, um aumento de 200 vezes comparado ao da população geral (Barr et al 1983).

Estudos realizados em animais mostram evidências da administração de etanol e ácido retinóico levando a HPE (Sulik e Johnston 1982, Siebert et al 1991, Kalter 1992, Sulik et al 1995). Além disso, foram observados casos de HPE em humanos associados ao consumo de álcool pela mãe durante o início da gestação (Bonneman e Meinecke 1990, Ronen e Andrews 1991, Coulter et al 1993). Também foi demonstrado que o excesso de ácido retinóico inibe a expressão das proteínas Sonic Hedgehog (Shh) e Patched (Ptc) no primórdio craniofacial de embriões de galinha. Considerando que essas proteínas são essencialmente importantes para o desenvolvimento do cérebro e estruturas mediais da face, estes resultados indicam uma participação importante também do ácido retinóico no desenvolvimento cerebral (Helms et al 1997, Cohen e Shiota 2002).

Desde 1963 existem relatos de ovelhas grávidas que se alimentaram da planta Veratrum califorcicum e tiveram crias com HPE (Binns et al 1963). Dois componentes isolados desta planta, ciclopamina e jervina, são estruturalmente similares ao colesterol, e por isso podem funcionar como inibidores da síntese do mesmo (Keeler e Binns 1968).

Chamando a atenção para o papel dos inibidores da síntese do colesterol na etiologia da HPE (Ming e Muenke 1998), estes componentes foram pesquisados e revelaram estar envolvidos na via de sinalização de Shh, onde os tecidos-alvo falham em responder à sinalização desta proteína quando expostos a estes teratógenos (Cooper et al 1998, Incardona et al 1998, Incardona et al 2000). A síndrome de Smith-LemliOpitz, na qual há deficiência da enzima 7-dehidrocolesterol redutase (DHCR7), pode 
apresentar HPE entre suas manifestações, mostrando a existência deste mecanismo também em humanos (Kelley et al 1996).

Estima-se que a freqüência de anomalias cromossômicas em recém-nascidos com HPE varie de 24 a 55\% (Ming et al 1976, Croen et al 1996, Olsen et al 1997, Bullen et al 2001). Segundo relatos, de 121 casos de HPE investigados citogeneticamente, 50 apresentavam síndromes conhecidas (Croen et al 1996). Um estudo mais recente, realizado em crianças com HPE e idades entre três dias e 18 anos, revelou anomalias cromossômicas em apenas $9 \%$ dos casos. Considerando o fato de que anormalidades cromossômicas estejam associadas à maior probabilidade de abortos espontâneos e morte fetal, os autores sugerem que estes resultados refletem exatamente a diferença entre as amostras utilizadas em cada estudo. Assim, em estudo do qual foram excluídos os casos de aborto, morte fetal e natimortos, a taxa de anomalias cromossômicas encontradas foi mais baixa (Stashinko et al 2004).

\subsubsection{Aspectos moleculares}

Alguns genes têm se mostrado positivamente envolvidos com a etiologia de defeitos dentro do espectro holoprosencefálico, dentre eles o SHH, ZIC2, SIX3, TGIF, PTCH, TDGF1, GLI2 e DHCR7 (Roessler et al 1996, Brown et al 1998, Wallis et al 1999, Gripp et al 2000, de la Cruz et al 2002, Ming et al 2002, Roessler et al 2003, Shim et al 2004). O gene que apresenta maior freqüência de mutações em pacientes com HPE é o SHH (5-10\%), seguido por ZIC2 (3-5\%), SIX3 (1,5-4\%) e TGIF (1-1,5\%). Relatos de mutações nos genes PTCH, DHCR7, GLI2 e TDGF1 em pacientes com HPE são baseados em relatos isolados (Roessler et al 1996, Roessler et al 1997, Brown et al 1998, Nanni et al 1999, Wallis et al 1999, Gripp et al 2000, Brown et al 2001, Orioli et 
al 2001, de la Cruz et al 2002, Ming et al 2002, Roessler et al 2003, Dubourg et al 2004, Shim et al 2004).

\section{Gene SHH}

Estudos têm demonstrado que mutações no gene Sonic Hedgehog (SHH) são as principais responsáveis pela HPE (Belloni et al 1996, Roessler et al 1996).

O gene SHH é expresso na linha média do sistema nervoso em desenvolvimento. Segundo uma revisão feita por Roessler e Muenke (1998), Shh é expresso precocemente na notocorda e no assoalho da placa neural dos vertebrados, controla a modelagem das estruturas derivadas das células ventrais do mesoderma ântero-lateral, somitos, crescimento dos neurônios motores e indução dos neurônios dopaminérgicos do cérebro médio. Shh é expresso ao longo de toda a extensão rostrocaudal do sistema nervoso, incluindo cérebro anterior ventral e olhos, e contribui para a morfogênese craniofacial. Distúrbios na sinalização do Shh em determinado estágio do desenvolvimento podem resultar em redução significativa do tamanho da cabeça (Ahlgren e Bronner-Fraser 1999).

Em 1996 foram descritas as primeiras mutações no gene SHH (Roessler et al 1996) e, até o momento, mutações neste gene respondem pelo maior número de casos de HPE diagnosticados geneticamente.

\section{Gene GLI2}

Gli2 é um dos três fatores de transcrição em vertebrados que desempenha a função de mediador obrigatório na transdução de sinais na via de Shh. Mutações com perda de função no gene GLI2 humano foram associadas com um fenótipo característico que inclui alterações comuns ao espectro de HPE, como defeitos na formação da 
hipófise anterior e pan-hipopituitarismo, hipoplasia mediofacial e presença ou não de clivagem anormal dos hemisférios cerebrais (Roessler et al 2003).

\section{Gene SIX3}

Estudos mostram a participação do gene Six3 de vertebrados na formação da linha média do cérebro e olhos (Oliver et al 1995, Wallis e Muenke 1999). Análises realizadas em 280 pacientes com HPE esporádica e familial identificaram quatro mutações no gene SIX3 (Wallis et al 1999). Recentemente, um estudo de análise mutacional realizado em 200 pacientes com HPE revelou oito mutações no gene SIX3 (Pasquier et al 2000, Dubourg et al 2004).

Alguns autores sugerem a expressão do gene SIX3 na formação do tronco encefálico (Kikuta et al 2003, Tallafuss et al 2003).

\section{Gene TGIF}

Alguns autores sugerem que mutações em TGIF que levassem a perda de função como repressor poderiam causar hiperatividade dos genes regulados pelo ácido retinóico, resultando em simulação do efeito da exposição excessiva a este (Muenke e Beachy 2001). Sete mutações em TGIF foram descritas em pacientes com HPE (Gripp et al 2000, Chen et al 2002, Aguilella et al 2003). Fissuras de lábio e/ou palato e agenesia de pré-maxila foram identificadas em cinco de sete pacientes e cebocefalia foi observada em um dos dois restantes com HPE e mutação em TGIF. Entre os pais dos pacientes, pelo menos três tinham a mesma mutação de seus filhos, sugerindo que outros fatores adicionais, genéticos ou ambientais, poderiam contribuir para determinar o fenótipo de HPE. 


\section{Gene Patched}

O gene $P T C H$ humano é um gene supressor tumoral no qual a perda da função causa a síndrome de Gorlin ou síndrome do nevus de células basais. Esse gene, assim como o $S M O$, é receptor transmembranas do SHH. Acredita-se que mutações gerando um ganho da função do $P T C H$ ou perda da função do $S M O$ podem levar ao desenvolvimento de anomalias tais como as vistas em HPE (Roessler e Muenke, 1998).

\subsection{POTENCIAIS EVOCADOS AUDITIVOS DE TRONCO ENCEFÁLICO- PEATE}

Os PEATE são potenciais de curta latência registrados a partir do fornecimento de uma estimulação acústica e obtidos da atividade elétrica cerebral resultante. São registrados de forma não invasiva e mesmo a sedação ou anestesia, quando necessárias, não interferem no resultado, tornando sua utilização e aplicação clínica muito difundidas. Soma-se ainda o fato de ser mínima a necessidade de colaboração do paciente para a realização do exame, uma vez que não exige resposta, apenas sua permanência em estado de relaxamento e sem atividade motora. Por isso, medidas dos PEATE são referidas como um método objetivo de avaliação do status do sistema auditivo periférico e central (Hall 1992).

\subsubsection{Estruturas Geradoras do PEATE}

A definição de estruturas geradoras do PEATE mais utilizada atualmente foi sintetizada por Hood (1998), a partir das classificações de Møller, em 1994 e Moore, em 1987. 
Onda I - originária da porção distal do oitavo (VIII) par craniano;

Onda II - originária principalmente da porção proximal do VIII par craniano, com a possibilidade de uma pequena contribuição da porção mais distal do nervo auditivo;

Onda III - originária principalmente dos neurônios do núcleo coclear, com a possível contribuição de fibras que chegam a essa estrutura;

Onda IV - a geração neural desta onda é incerta, apesar dos neurônios de terceira ordem do complexo olivar superior estarem mais envovidos. Outras contribuições incluem o núcleo coclear e o lemnisco lateral;

Onda V - originária da ativação do lemnisco lateral e do colículo inferior, no tronco encefálico.

Deve ser enfatizado que os picos IV, V, VI e VII do PEATE têm origem complexa, com mais de uma estrutura anatômica contribuindo para a formação de cada pico. Os únicos sítios obrigatórios de sinapse, nas vias auditivas do tronco encefálico, são o núcleo coclear e o colículo inferior e entre essas vias existe uma série de vias paralelas.

\subsubsection{Síntese da anatomofisiologia das vias auditivas}

Alguns aspectos principais da anatomofisiologia da audição, segundo Munhoz e Silva (1996), serão descritos abaixo de forma sintetizada para um melhor entendimento do processamento de estímulos auditivos nas estruturas do tronco encefálico, responsáveis pela geração dos potenciais.

O nervo auditivo inicia seu trajeto junto às células ciliadas (órgão de Corti) e vai até os núcleos cocleares no tronco encefálico mantendo uma organização tonotópica, a exemplo da cóclea. Assim sendo, suas fibras mais periféricas são responsáveis pelas 
freqüências agudas, que vêm da base da cóclea, enquanto as fibras centrais respondem às freqüências graves, provenientes do ápice da cóclea.

Os núcleos cocleares dorsal, ventral anterior e ventral posterior estão situados na superfície da ponte, em sua porção mais caudal, logo abaixo do pedúnculo cerebelar. Os núcleos cocleares enviam feixes de fibras chamados de dorsais, intermediários e ventrais, para diversas estruturas como: complexo olivar, lemnisco lateral e colículo inferior. Preferencialmente, porém, todas as fibras cruzam e estabelecem conexões com os núcleos do complexo olivar contralateral. Os núcleos cocleares auxiliam na função de seleção e modulação de freqüências e iniciam o processo de audição biaural por meio de mecanismos de excitação-inibição da transmissão dos sons captados.

O complexo olivar, situado também no mesmo nível da ponte, recebe as fibras oriundas dos núcleos cocleares em seus núcleos pré-olivar, lateral e medial, sendo que próximo a estes situam-se os núcleos do corpo trapezóide. No complexo olivar, originam-se as fibras mais periféricas do sistema auditivo eferente e no feixe olivococlear passam as outras fibras descendentes mais centrais desse sistema. A função primordial do complexo olivar, que parece estar relacionada com a audição biaural, é exercida por meio da análise de diferenças de interesse e tempo dos sons recebidos de ambos os lados. Além disso, o reforço do sistema de transmissão de informações se dá por pulsos, em períodos de tempo determinado.

Na parte alta da ponte estão situados os feixes e núcleos do lemnisco lateral. Esse sistema recebe fibras contralaterais dos núcleos cocleares e do complexo olivar. As fibras do lemnisco lateral também são superficiais e mantêm um forte sistema de conexão entre os núcleos situados nos dois lados.

No mesencéfalo situam-se os núcleos do colículo inferior, que recebem fibras diretas e indiretas dos demais núcleos, localizados topograficamente abaixo deles. 
Existe uma forte conexão entre os núcleos dos dois lados, sendo esta a última etapa na qual a via auditiva estabelece cruzamento direto de fibras. O colículo inferior, além de ser um importante centro de conexão da via auditiva aferente e eferente, exerce uma função primordial: a audição direcional. Do colículo inferior saem fibras para o subcórtex e córtex auditivo. Ver esquema ilustrativo na Figura 4.

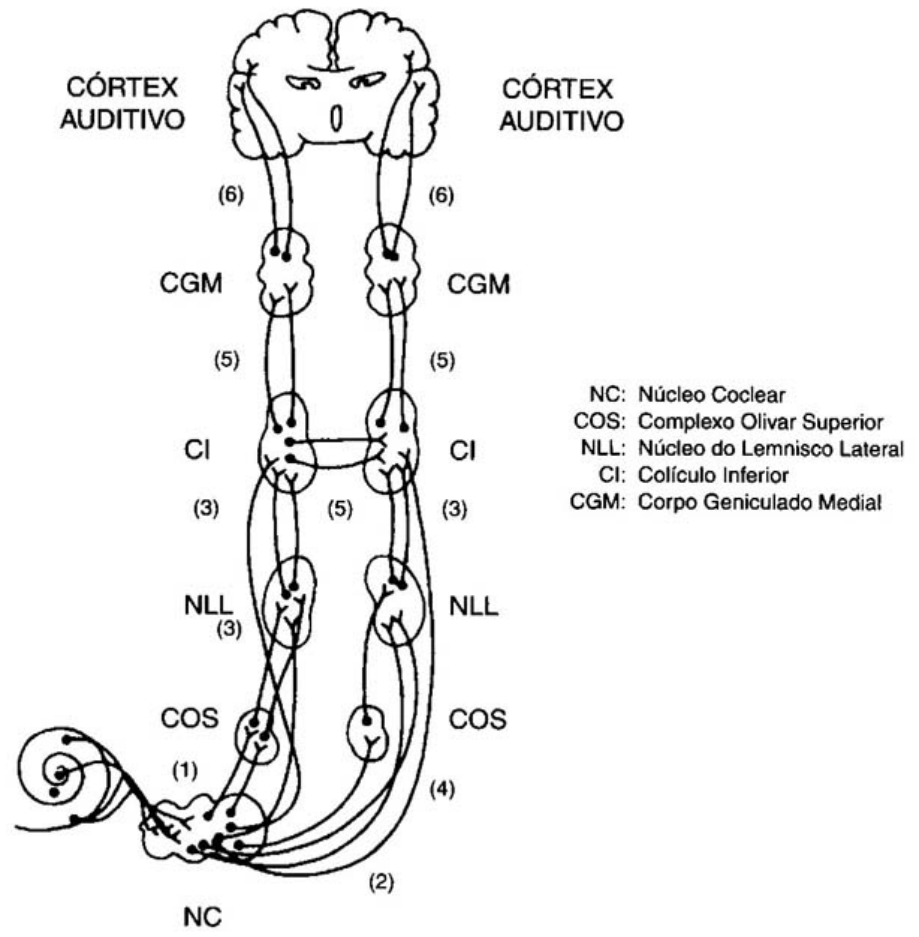

Figura 4 -Esquema ilustrativo das vias auditivas centrais (Katz 1999).

\subsubsection{Registro do PEATE}

A forma mais empregada para a obtenção do PEATE é a utilização de eletrodos no escalpo. Os PEATE são captados por meio de eletrodos metálicos e transferidos por fios condutores até os amplificadores do equipamento de registro. Diferenças de potencial são registradas entre um par de eletrodos: o primeiro é um eletrodo chamado ativo ou positivo, que pode estar situado no escalpo - vértice ou parte central alta da fronte - e o outro, de referência, também chamado de eletrodo negativo, é colocado no 
lóbulo da orelha da orelha a ser testada, ou na mastóide do mesmo lado. Existe ainda um terceiro eletrodo, que funciona como terra, chamada de eletrodo massa ou terra, que pode ser colocado na fronte ou até mesmo na mastóide oposta ao eletrodo referência. Essa variação na colocação do eletrodo terra geralmente está relacionada ao equipamento utilizado, podendo apresentar três ou quatro cabos para a conexão dos eletrodos. Quando existem apenas três cabos para conexão, o eletrodo colocado na mastóide contralateral funciona como terra.

Todos os eletrodos devem estar conectados a um pré-amplificador.

Técnicas adequadas para diminuir efeitos indesejáveis, que podem contaminar o registro, são empregadas para a confecção de eletrodos, como a utilização de metais, geralmente a prata, chamados eletrodos de prata (cloreto de prata).

A partir da atividade elétrica cerebral, surgiram técnicas apropriadas para extrair o PEATE (Hall 1992) do total obtido. Microcomputadores são utilizados para processar as respostas e efetuar promediações entre o sinal desejado (no caso, o PEATE gerado por estímulos idênticos) e o ruído (sinal proveniente da atividade elétrica cerebral, não relacionado ao PEATE).

Durante a obtenção dos registros, o paciente deve estar comodamente instalado, para diminuir os artefatos de origem muscular, captados como ruído (Lolas e Hoeppner 1977, Hall 1992).

O sono, que pode ser estimulado para melhorar a qualidade do registro a ser obtido, não é condição obrigatória para a maioria dos indivíduos, mas passa a ser quando o indivíduo não consegue relaxar e ficar quieto, sem se movimentar.

Stockard e Rossitter (1977) demonstraram que o hidrato de cloral, utilizado para induzir o sono, não causa alterações nas respostas acusticamente evocadas do tronco encefálico. 
Quando o sono induzido é necessário, podem ser usados vários tipos de drogas, desde sedativos administrados por via oral, até drogas mais potentes, utilizadas em anestesia geral.

O hidrato de cloral continua sendo um dos principais sedativos utilizados para indução do sono não interferir na geração dos potenciais e por praticamente não apresentar riscos e efeitos adversos, quando administrado na dose adequada. Entretanto, cuidados devem ser tomados na utilização de qualquer tipo de droga, por razões médicas e legais (Hall 1992).

Sequeira e Fukuda (1988), com o objetivo de estabelecer parâmetros de normalidade, empregaram para a captação e registro do PEATE, um par de eletrodos negativos (ou de referência) fixos nas mastóides direita e esquerda, um eletrodo terra (ou de massa) colocado na parte posterior do pescoço, abaixo da linha de implantação dos cabelos e, por último, um eletrodo positivo (ou ativo) fixado na fronte, ao nível do plano sagital, correspondendo à porção logo abaixo da linha de implantação de cabelos. Os autores consideraram que os registros obtidos em pacientes com maior relaxamento apresentaram maior nitidez de respostas, sem, no entanto, influenciar sua latência ou amplitude.

\subsubsection{Parâmetros de análise do PEATE}

O registro do PEATE apresenta três principais características a serem consideradas: morfologia, amplitude e latência (Hall 1992).

Picton et al (1974) e Cazals et al (1978) mostraram que o valor da amplitude dos registros de PEATE estava sujeito a consideráveis variações.

A morfologia e a amplitude geralmente não são diretamente analisadas na rotina clínica, apesar de carregarem importantes informações sobre as condições de condução 
neural das vias auditivas. Uma das justificativas e a principal, para ambas as características, é a grande variabilidade do normal, encontrada no registro das ondas, fato este que não permite a diferenciação entre achados normais e anormais (Hall 1992, Costa Filho e Celani 1993).

$\mathrm{Na}$ interpretação do registro de PEATE, a característica principal analisada é a latência, composta de três parâmetros: o primeiro, a latência absoluta da onda, é o intervalo de tempo entre a apresentação do estímulo auditivo e o pico da onda e tem, como unidade de medida, o milissegundo (ms). A latência da onda do PEATE é a característica mais confiável e o aspecto mais importante. Sabe-se que, quanto maior a intensidade do estímulo, menor será a latência absoluta da onda, sendo, portanto, a latência inversamente proporcional à intensidade do estímulo. As latências absolutas geralmente mais analisadas I, III e V. O segundo parâmetro, a medida entre os picos (latência interpicos), é o tempo transcorrido entre os picos registrados. Em contraste com a latência absoluta, relacionada com o início do estímulo apresentado, o intervalo de latência interpico usa a latência do pico mais precoce como referência. Os interpicos mais comumente analisados são I-III, III-V e I-V. O terceiro parâmetro, a diferença da latência interaural, compara a latência absoluta da onda $\mathrm{V}$ obtida no lado direito versus a obtida no lado esquerdo, em níveis de intensidade iguais (Hood 1998).

A latência absoluta das ondas, geradas pelas diversas estruturas envolvidas na obtenção do PEATE, aumenta à medida que se afasta da cóclea (Costa Filho e Celani 1993). A latência absoluta tem variação relativamente pequena para cada onda, entre as principais (I, III e V), para os indivíduos normais. Existem, porém, variações nos valores considerados normais, decorrentes principalmente do equipamento, tipo de eletrodo, forma de colocação, pasta eletrolítica utilizada, dentre outros. 


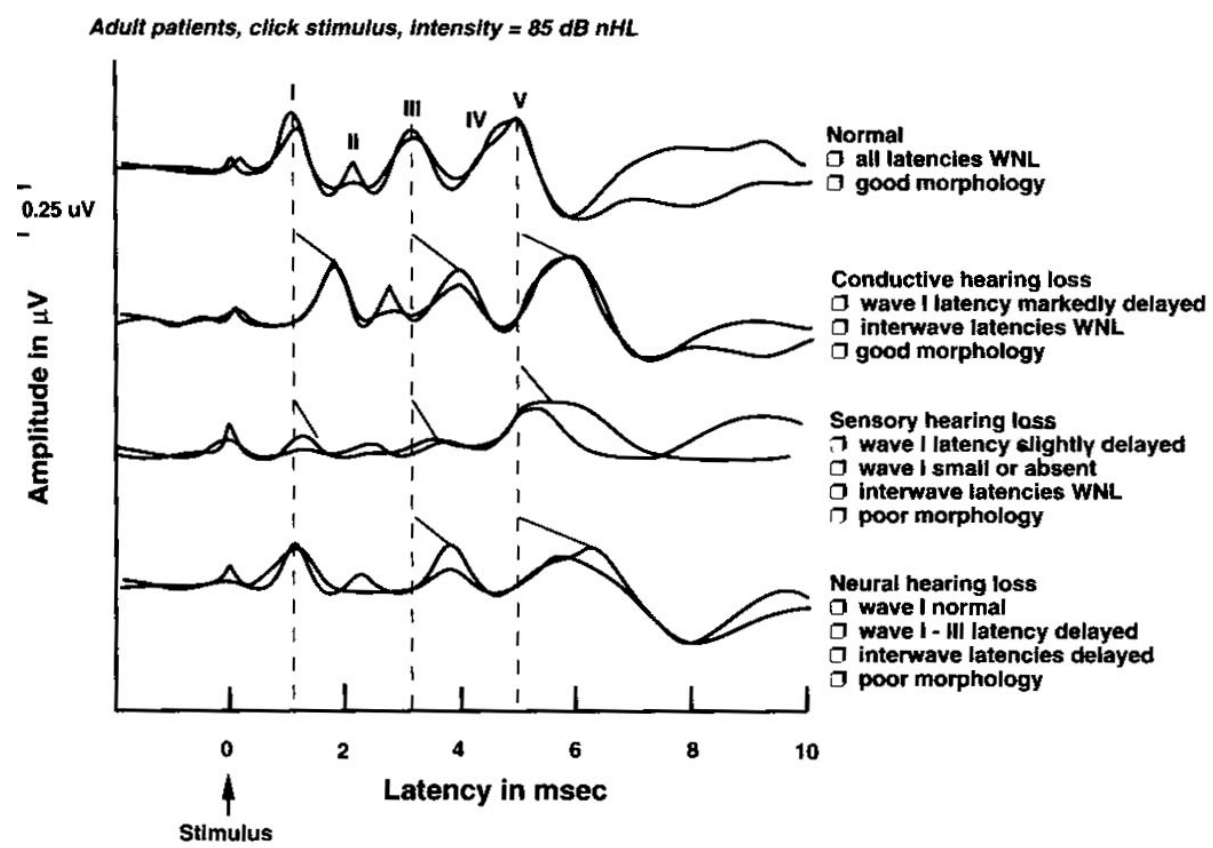

Figura 5 - Morfologia normal de ondas do PEATE, seguido pelos traçados vistos em perdas condutivas, sensorioneurais e neurais, respectivamente (Hall e Mueller, 1997).

\subsubsection{Valores de latência do PEATE}

Com relação aos valores de latência, Jewett e Williston (1971), que pela primeira vez descreveram as estruturas geradoras e as latências no registro do PEATE apresentaram valores para latência absoluta de 1,5 ms para a onda I; de 3,5 ms para a onda III e de 5,1 ms para a onda V.

Chiappa et al (1979) apresentaram os valores de 1,8 ms para a onda I; 4,2 ms para a onda III e $6,2 \mathrm{~ms}$ para a onda $\mathrm{V}$.

Os valores de latência absoluta apresentados por Stockard et al (1979) foram: onda I - 1,69 ms; onda III - 3,72 ms e onda V - 5,64 ms.

Valores de latência absoluta de 1,76 ms para onda I, de 3,86 ms para onda III e de 5,63 ms para onda $\mathrm{V}$, considerando variação de $0,2 \mathrm{~ms}$ para as ondas I, III e $\mathrm{V}$, foram obtidos por Sequeira e Fukuda (1988). 
Costa Filho e Celani (1993) apresentaram valores de latência absoluta, compilados de vários laboratórios internacionais: onda I - 1,5 a 1,9 ms; onda III - 3,5 a 4,1 ms e onda V - 5,0 a 5,9 ms. Esses autores também apresentaram as seguintes latências interpicos como parâmetro de normalidade: Interpico I-III $=1,8$ a 2,4 ms; Interpico III-V = 1,7 a 2,2 ms; Interpico I-V = 3,7 a 4,4 ms. Hall e Mueller (1997) consideraram que o interpico I-V não deve exceder 4,5 ms em indivíduos normais.

Hood (1998) apresentou, para indivíduos normais, as seguintes latências interpicos: I-III e III-V aproximadamente $2,0 \mathrm{~ms}$ e I-V aproximadamente 4,0 ms, podendo variar mais ou menos $0,4 \mathrm{~ms}$.

Chu (1985) realizou um estudo com PEATE abordando os efeitos da idade e do gênero nos resultados. Observou que tanto as latências absolutas quanto as interpicos foram consistentemente menores para o gênero feminino. Os efeitos atribuídos à diferença de gênero foram observados em todos os grupos de idade.

Rodriguez et al (1989) relataram, em um estudo com 50 indivíduos normais do ponto de vista audiológico e sem enfermidades que pudessem alterar o PEATE, que a latência da onda $\mathrm{V}$, considerando a variável gênero, foi de 0,1 a $0,2 \mathrm{~ms}$ menor para o gênero feminino, em relação ao masculino. Esses mesmos autores enfatizaram a necessidade de determinar os valores normais para cada equipamento, uma vez que estes podem não coincidir com os valores de outros equipamentos.

Macedo et al (1990) realizaram estudo sobre PEATE em 80 indivíduos audiologicamente normais com idades entre 50 e 74 anos, sendo 40 homens e 40 mulheres. Verificaram que os homens apresentam tempo de latência absoluta das ondas maior que as mulheres, contudo ressaltam em sua conclusão que essas diferenças não são significativas para a prática clínica. 
A diferença interaural é considerada pela maioria dos pesquisadores, dentre eles Hall e Mueller (1997) e Hood (1998) como significativa, ou seja, fora dos padrões de normalidade quando excede a $0,4 \mathrm{~ms}$. Ela é analisada principalmente para a onda $\mathrm{V}$.

Demais pesquisadores, como Hall (1992), Costa Filho e Celani (1993), Hall e Mueller (1997) e Hood (1998) também reafirmam essa premissa.

\subsubsection{Características do estímulo e parâmetros mais utilizados}

O tipo de estímulo auditivo mais utilizado nas investigações eletrofisiológicas é o click transiente de banda larga, gerado quando se aplica um pulso de curta duração, geralmente de 0,1 ms (Hall e Mueller 1997). O espectro de freqüência gerado por esse tipo de estímulo auditivo é amplo, porém sua energia máxima concentra-se entre 2 e 4 kHz (Hall e Mueller 1997).

Rotineiramente, a taxa de apresentação do estímulo na pesquisa do PEATE encontra-se entre 20 e 30 clicks por segundo (Hall e Mueller 1997, Hood 1998), pois falsos resultados podem ser encontrados com taxas muito baixas ou muito elevadas, decorrentes de variações interindivíduos, como idade, por exemplo.

A estimulação geralmente ocorre de forma monoaural, isto é, a pesquisa dos PEATE se faz de um lado por vez, ou direito ou esquerdo, e ipsilateralmente, isto é, o eletrodo referência é colocado no mesmo lado estimulado (Hall e Mueller 1997).

O total de promediações pode estar entre 500 e 4000, dependendo das condições de registro do exame (Hall e Mueller 1997). Entretanto, os somatórios mais aceitos são de 1000 ou 2000 clicks por traçado registrado.

O tempo de registro considerado após a estimulação, também referida como janela, é de 10 ou 15 ms. A janela de 15 ms pode ser utilizada para pesquisa com bebês, 
pois apresentam latências mais elevadas, em função da maturação auditiva, que é completada por volta dos 18 meses de vida, ou para indivíduos com perdas condutivas, que têm, como característica, o aumento nas latências absolutas das ondas (Hall e Mueller 1997).

A intensidade do estímulo a ser apresentado pode sofrer grande variação, dependendo do motivo pelo qual o exame foi solicitado. Quando a indicação é para pesquisa de integridade da via auditiva, utiliza-se, normalmente, intensidade entre 80 e 95 dBnHL, para ser possível a visualização das três ondas principais (I, III e V) e se obter as latências interpicos (I-III, III-V, I-V). Dependendo do grau da perda, não é possível esta análise. Já quando a indicação é para pesquisa de nível mínimo de resposta, a intensidade do estímulo apresentado pode chegar a $0 \mathrm{dBnHL}$ (Hall e Mueller 1997). Existem ainda dois motivos secundários para a variação na intensidade do estímulo: um, decorrente da calibração utilizada ou permitida pelo equipamento, ou seja, dBnHL ou dBSPL e outro, oriundo das intensidades mínima e máxima fornecidas pelo equipamento.

A última característica do estímulo e talvez a mais polêmica e divergente na utilização clínica é a polaridade. Ela pode ser positiva, negativa ou alternada. A polaridade positiva ou condensação ocorre quando existe um movimento inicial do diafragma do fone em direção à membrana timpânica; a polaridade negativa ou rarefação ocorre quando existe um movimento inicial do diafragma do fone em direção contrária à membrana timpânica e a polaridade alternada é obtida através do fornecimento de um pulso positivo e um negativo apresentados seqüencialmente (Hall e Mueller 1997, Hood 1998).

A grande divergência relativa ao padrão de polaridade a ser utilizado na prática clínica ocorre principalmente em função da representação da onda I. Alguns 
pesquisadores (Hall e Mueller 1997 e Hood 1998) explicam a preferência pela utilização da polaridade negativa sobre a alternada, pelo fato do registro da onda I apresentar-se de forma mais pobre na polaridade alternada, com menor amplitude e pior morfologia ou até a sua possível não visualização. Referem ainda uma morfologia mais pobre para as outras ondas, pois as polaridades positiva e negativa nem sempre desencadeiam respostas exatamente com a mesma latência.

Outros pesquisadores justificam a escolha pela polaridade alternada, por esta apresentar o cancelamento do artefato inicial, gerado pela própria estimulação.

No Brasil, muitos pesquisadores responsáveis ou atuantes em centros de referência em audiologia, utilizam a polaridade alternada na rotina clínica de investigação (Sequeira e Fukuda 1988, Costa Filho e Celani 1993).

Em um estudo realizado com 40 adultos jovens normais, para obter a média dos limiares, Stapells et al (1982) relataram não existir diferenças significativas no limiar auditivo para clicks entre estímulos de condensação e rarefação.

Sequeira e Fukuda (1988) realizaram a pesquisa do PEATE em 40 indivíduos normais, de ambos os sexos, com idades entre 18 e 26 anos, a fim de estabelecer parâmetros de normalidade para a análise. Foi aplicado estímulo tipo click de polaridade alternada, em intensidade de 100 dBNPS, com velocidade de apresentação de 13 clicks por segundo, perfazendo um total de 1000 a 2000 estímulos por registro. A pesquisa ocorreu de forma monoaural e ipsilateral.

Macedo et al (1990) apresentaram um estudo sobre PEATE em 80 indivíduos audiologicamente normais, com idades entre 50 e 74 anos, sendo 40 homens e 40 mulheres, utilizando clicks de polaridade alternada, na intensidade de 100 dBNPS, na apresentação de 13 estímulos por segundo, na obtenção de parâmetros de latência. 


\subsection{ESTUDOS AUDIOLÓGICOS E HPE}

Na literatura nacional e internacional da área da audiologia, não há registros de trabalhos com o objetivo de estudar a função auditiva por meio dos PEATE na HPE.

Um estudo envolvendo diversos potenciais evocados em alguns tipos definidos de malformações cerebrais, dentre elas a HPE, foi realizado em 1990 por Coupland e Sarnat. Anormalidades nos potenciais evocados auditivos (ABR) foram documentadas nos casos de HPE, lissencefalia, paquigiria e megalencefalia generalizada, mas não ocorreram nos casos de displasia septo-ótica ou displasia focal do córtex cerebral. Esses autores concluíram que os potenciais evocados, de uma forma geral, não são um critério diagnóstico para displasias severas, mas podem servir como ferramenta suplementar para detectar anomalias associadas ao desenvolvimento do cérebro que podem afetar as vias centrais visuais e auditivas em seus alvos corticais ou do tronco encefálico (Coupland e Sarnat, 1990).

Shoda et al (1990) relataram um caso de HPE alobar com comprometimento severo do desenvolvimento do Sistema Nervoso Central. O paciente era do gênero masculino, com dois meses de idade e tinha facies peculiar, com microcefalia e subdesenvolvimento da testa. A ecoencefalografia mostrou malformação cerebelar e um único ventrículo acompanhado de hidrocefalia severa; entretanto, seu tronco encefálico e cerebelo puderam ser confirmados. O eletroencefalograma mostrou ondas completamente achatadas e não foram obtidas respostas nos testes de potenciais evocados visuais (VEP) e auditivos (ABR). Nenhuma anormalidade cromossômica foi encontrada.

Kraus et al (1984) avaliaram 40 pacientes com hidrocefalia por meio dos PEATE, dos quais $80 \%$ apresentaram algum tipo de anormalidade. As respostas 
indicativas de disfunção de tronco encefálico consistiram de latência interpicos I-V aumentada (38\%), amplitude $\mathrm{V}$ reduzida (33\%) e anormalidades na configuração das ondas III (27\%) e V (53\%). Em adição, 70\% dos pacientes tiveram limiares eletrofisiológicos aumentados. Os autores sugeriram que a disfunção de tronco encefálico dificulta a mensuração da sensitividade auditiva nos pacientes com hidrocefalia

Castro Júnior et al (2000) relataram um caso de HPE no qual foi realizada avaliação audiológica objetiva. A paciente avaliada tinha três meses de idade e diagnóstico de HPE alobar. Os resultados revelaram emissões otoacústicas produto de distorção normais e PEATE com presença das ondas I e III, com latência interpicos I-III aumentada e ausência de onda $\mathrm{V}$, confirmando o comprometimento auditivo funcional do tronco encefálico, compatível com os achados do diagnóstico por imagem.

Um estudo bastante recente, publicado em 2006 por Jing et al, relata a aplicação de potenciais evocados auditivos de longa latência em crianças com HPE do tipo semilobar. A casuística foi composta por 7 crianças divididas em 3 categorias etárias: 16, 36 e 60 meses, das quais 3 eram do gênero masculino e 4 do feminino. Os resultados dos pacientes com HPE, quando comparados aos do grupo controle, mostraram maiores latências e menores amplitudes, sugerindo uma resposta lenta a estímulos auditivos seqüenciais rápidos. Esses autores atribuem as anormalidades às malformações cerebrais, envolvendo córtex, tálamo e ventrículos e reforçam a necessidade de avaliar mais detalhadamente estruturas subcorticais, sugerindo para isso a utilização do PEATE. 


\section{OBJETIVOS}

\subsection{Objetivo Geral}

Descrever o perfil audiológico e a funcionalidade das vias auditivas no nível do tronco encefálico em indivíduos com Holoprosencefalia e Holoprosencefalia-like por meio dos Potenciais Evocados Auditivos de Tronco Encefálico.

\subsection{Objetivos Específicos}

3.2.1 Caracterização da casuística estudada quanto ao gênero, idade e tipo de malformação craniofacial;

3.2.2 Obtenção, avaliação e comparação dos achados dos Potenciais Evocados Auditivos de Tronco Encefálico em indivíduos com HPE e HPE-like;

3.2.3 Estudo da relação entre a gravidade do quadro e a presença de mutação genética com os achados audiológicos. 


\section{MATERIAL E MÉTODO}

O presente estudo foi realizado no Setor de Genética Clínica do Hospital de Reabilitação de Anomalias Craniofaciais (HRAC), da Universidade de São Paulo (USP

- Bauru), iniciado após aprovação do Comitê de Ética em Pesquisa deste hospital, atendendo a todos os dispositivos das Resoluções 196/96 e 251/97 e aprovado sob o protocolo $\mathrm{n}^{\circ}$ 072/2006-UEP-CEP, de 3 de maio de 2006 (Anexo 1).

\subsection{Seleção da Casuística}

A seleção da casuística foi realizada a partir de levantamento do registro de pacientes com diagnóstico de holoprosencefalia (HPE) junto ao Centro de Processamento de Dados (CPD) do HRAC-USP, buscando aqueles com diagnóstico de HPE e de HPE-like. Além destes, que já tinham diagnóstico prévio, foram incluídos os casos novos que, por procedimento de rotina do hospital, foram atendidos no Setor de Genética e tiveram o quadro de HPE ou HPE-like diagnosticado.

Todos os pacientes e seus responsáveis foram convidados a participar do estudo e a assinarem o Termo de Consentimento Livre e Esclarecido (Anexo 2), após leitura da Carta de Informação ao Paciente (Anexo 3). Somente os pacientes ou responsáveis que assinaram esse termo, confirmando assim sua concordância e adesão ao estudo, foram incluídos na casuística. 


\subsection{Casuística}

Participaram deste estudo 57 indivíduos, na faixa etária de 18 meses a 22 anos, de ambos os gêneros, subdivididos em grupos de acordo com o diagnóstico clínico de HPE ou HPE-like, além dos indivíduos do grupo controle (Tabela 1).

4.2.1 Grupo com HPE clássica (GH): composto por 13 indivíduos com a seqüência de Holoprosencefalia, sendo 5 do gênero masculino e 8 do gênero feminino, com idades entre 18 meses e 6 anos. Quanto ao tipo de HPE, 7 apresentavam o tipo alobar, 4 o tipo semilobar e 2 o tipo lobar.

4.2.2 Grupo com HPE-like (GHL): composto por 22 indivíduos, sendo 5 do gênero masculino e 17 do gênero feminino, com idades entre 2 e 22 anos, portadores de sinais clínicos dentro do espectro da HPE ou microformas da mesma, como hipotelorismo, microcefalia, hipoplasia de face média e incisivo central único.

4.2.3 Grupo Controle (GC): composto por 22 indivíduos normais, sendo 15 do gênero feminino e 7 do gênero masculino, sem queixas ou alterações auditivas, comprovado por audiometria tonal limiar e imitanciometria, pareados por gênero e idade aos grupos experimentais segundo orientações estatísticas. Esse grupo foi formado com voluntários da cidade de Bauru que demonstraram interesse em participar da pesquisa após divulgação da mesma. 
TABELA 1 - Distribuição dos indivíduos estudados quanto ao gênero e idade.

\begin{tabular}{cccccccc}
\hline \multirow{2}{*}{ GRUPO } & \multicolumn{2}{c}{ GÊNERO } & \multicolumn{5}{c}{ IDADE (meses) } \\
\cline { 2 - 8 } & Masculino & Feminino & Média & Mediana & Desvio Padrão & Mínimo & Máximo \\
\hline GH (13) & $5(38 \%)$ & $8(62 \%)$ & 45 & 36 & 40.71 & 18 & 168 \\
\hline GHL (22) & $5(23 \%)$ & $17(77 \%)$ & 116 & 102 & 72.88 & 24 & 264 \\
\hline GC (22) & $7(32 \%)$ & $15(68 \%)$ & 103 & 90 & 72.84 & 18 & 264 \\
\hline
\end{tabular}

\subsection{Critérios de Inclusão}

Para serem incluídos neste estudo, os participantes deveriam obedecer a alguns critérios, variando de acordo com cada grupo.

- No Grupo H (HPE clássica), foram incluídos indivíduos com diagnóstico de HPE, independendo de gênero ou idade, que estivessem em condições de saúde e bemestar geral para a realização dos exames;

- No Grupo HL (HPE-like), foram incluídos indivíduos com fenótipo HPE-like, independendo de gênero ou idade e hígidos.

- No Grupo C (Controle), foram incluídos indivíduos sem queixas auditivas ou histórico de otites, com gênero e idade pareados aos indivíduos dos grupos experimentais 


\subsection{Critérios de Exclusão}

Foram estabelecidos critérios de exclusão para os indivíduos do estudo, de acordo com o grupo a que pertenciam.

- Em relação ao Grupo H (HPE clássica), foram excluídos da amostra indivíduos com outras características além da HPE, como síndromes associadas ou múltiplas malformações e indivíduos que não colaboraram para a realização dos testes;

- Em relação ao Grupo HL (HPE-like), foram excluídos da amostra indivíduos com manifestações além das características do fenótipo HPE-like e indivíduos que não colaboraram para a realização dos testes;

- Em relação ao Grupo C (Controle), foram excluídos os indivíduos que não colaboraram para a realização de todos os testes, uma vez que a maior parte do grupo foi composta por crianças, e aqueles com alterações na audiometria (perda auditiva) e/ou imitanciometria.

\subsection{Procedimento}

Os procedimentos realizados neste estudo foram divididos em duas fases; Fase 1, que consistiu no estabelecimento do padrão de normalidade para o equipamento utilizado e Fase 2, que foi a realização do PEATE nos grupos estudados. 


\subsubsection{FASE 1- Calibração biológica do equipamento}

Esta etapa consistiu na calibração biológica do equipamento para mensuração do PEATE (BERAmodul, da marca HORTMANN Neuro-otometrie) realizada com 10 indivíduos normais, sem queixa auditiva atual ou pregressa e audição periférica normal demonstrada pela audiometria, na faixa etária de 20 a 30 anos, sendo 5 do gênero masculino e 5 do gênero feminino. Conforme relatado no capítulo de revisão de literatura, este procedimento faz-se de grande importância devido às variações entre as diversas condições de testagem, incluindo o tipo de aparelho, o tipo de tratamento acústico da sala e o tipo de eletrodo utilizado.

\subsubsection{FASE 2 - Coleta de dados}

\subsubsection{AVALIAÇÃO AUDIOLÓGICA}

Os procedimentos descritos neste item foram realizados em todos os indivíduos de todos os grupos estudados.

Anamnese: Procedimento utilizado para obter informações específicas sobre o desenvolvimento auditivo e de linguagem, bem como sua condição atual. Para isso, foi questionada a presença de queixa auditiva atual (otite, otalgia, otorréia, hipoacusia e outros) e pregressa, histórico de surdez familial, doenças, uso de medicamentos, traumas e cirurgias otológicas realizadas ou indicadas. 
Inspeção otológica: Foi efetuada visualização do meato acústico externo e da membrana timpânica, para descartar a possível presença de alterações que poderiam comprometer a confiabilidade dos resultados, como a presença de corpo estranho, tubo de ventilação ou rolha de cera. Para isso, foi utilizado um otoscópio de fibra ótica, modelo standard N 2.5V, da marca Heine.

Imitanciometria: Exame que permitiu avaliar as condições funcionais da orelha média. Composto pela timpanometria e pesquisa do reflexo acústico, forneceu medidas imprescindíveis para a correta interpretação dos achados do PEATE, pois é sabido que a presença de patologia condutiva pode interferir diretamente nos resultados. As curvas timpanométricas foram classificadas em 5 tipos:

- Tipo A: Indicativa de normalidade da orelha média, com complacência entre 0,3 e 1,3 ml e pressão do pico de máxima complacência próximo de $0 \mathrm{daPa}$, sendo considerados como normais valores entre -100 e +100 daPa em adultos e entre -150 e +90 daPa em crianças.

- Tipo Ar: Indicativa de rigidez da membrana timpânica, com complacência menor que $0,3 \mathrm{ml}$ e pressão próxima de $0 \mathrm{daPa}$.

- Tipo Ad: Indicativa de disjunção de cadeia ossicular ou membrana timpânica monomérica, com complacência maior que $1,3 \mathrm{ml}$ e pressão próxima de $0 \mathrm{daPa}$.

- Tipo B: Indicativa de secreção na orelha média, sem pico de máxima complacência.

- Tipo C: Indicativa de disfunção tubária, com complacência dentro na normalidade e pico deslocado para as pressões negativas. 
O aparelho utilizado foi da marca Siemens, modelo SD-30, adequadamente calibrado por pessoal qualificado.

\section{Potenciais evocados auditivos de tronco encefálico (PEATE)}

Realizado para avaliar a integridade funcional das vias auditivas periférica e central.

a) Parâmetros de estímulo: A pesquisa do PEATE foi realizada com registro ipsilateral em ambas as orelhas. O tipo de estímulo apresentado foi o click, com espectro de freqüência entre 1000 e $4000 \mathrm{~Hz}$, cuja faixa principal encontrava-se entre 2, 3 e 4 kHz. A duração do click foi de 0,1 ms e o número de apresentações de 24 clicks por segundo. O tempo de análise utilizado foi de $10 \mathrm{~ms}$ e, quando necessário, foi aplicado o filtro, com corte para freqüências abaixo de $300 \mathrm{~Hz}$. Não foi empregado mascaramento, por não ter sido necessário, uma vez que, quando as respostas estavam presentes, não houve diferença interaural da onda $\mathrm{V}$ maior que $0,4 \mathrm{~ms}$, conforme proposto por Hall e Mueller (1997). As ondas foram registradas com o somatório de 1000 estímulos, com polaridade alternada e as intensidades pesquisadas foram de 80 dB, quando a audição periférica estava normal e o traçado claramente visível; de 90, 100 e $110 \mathrm{~dB}$ em casos com perda auditiva periférica ou naqueles em que o traçado estava alterado na intensidade inicial de $80 \mathrm{~dB}$, sendo efetuados três registros para cada intensidade. O estímulo foi apresentado através de fones de ouvido do tipo supra-aurais, modelo Beyerdynamic DT48, marca HORTMANN Neuro-Otometrie . 
Não foi realizada pesquisa de limiar eletrofisiológico, uma vez que o objetivo deste estudo não foi determinar a sensitividade auditiva, mas sim a integridade das vias auditivas.

b) Preparação do paciente: O paciente permaneceu deitado confortavelmente em uma maca, com o encosto cervical semi-reclinado, durante a obtenção do exame (Figura 6).

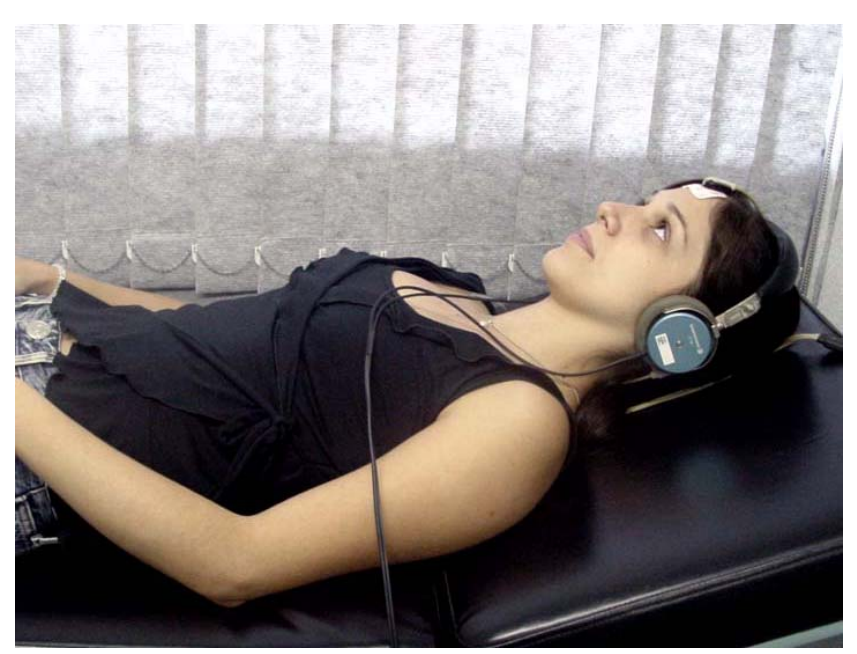

Figura 6 - Posição do paciente adotada para o registro do PEATE.

Foi efetuada limpeza da pele nos pontos onde seriam colocados os eletrodos para a remoção dos resíduos de descamação epitelial, sudorese e cosméticos e, em seguida, foi aplicada pasta eletrolítica para auxiliar na condução e captação do potencial pelo eletrodo. Ambos os recursos tiveram por objetivo melhorar o contato entre o eletrodo e a pele, permitindo a obtenção de registros mais nítidos. Foram utilizados eletrodos para monitorização 4350, da marca 3M com pasta eletrolítica TEN20 Conductive, dispostos da seguinte forma: eletrodo ativo na fronte $(\mathrm{Fz})$, referência sobre a mastóide do lado testado e o terra sobre a mastóide do lado oposto. 
O exame foi realizado dentro de sala acusticamente tratada, com o aparelho BERAmodul, da marca HORTMANN Neuro-otometrie, acoplado a um microcomputador da marca IBM e uma impressora da marca HP, 692C (Figura 7).

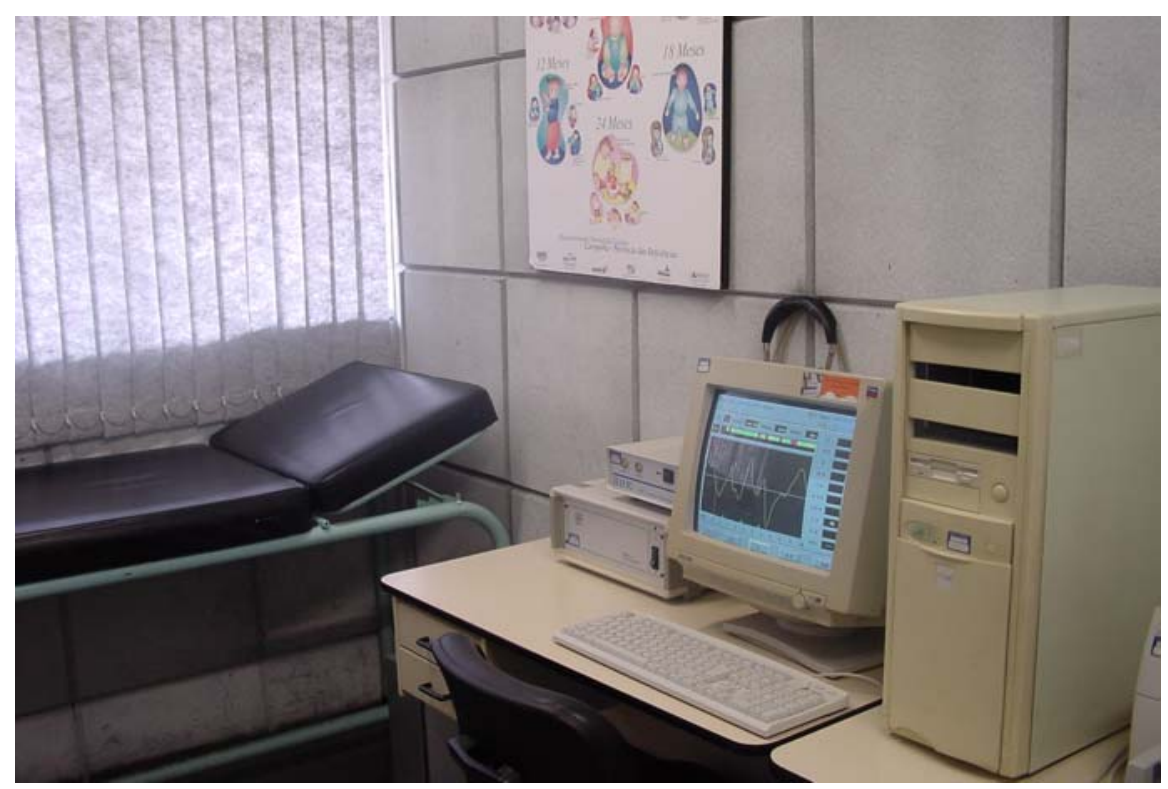

Figura 7 - Equipamento utilizado, sala acusticamente tratada e maca para acomodação do paciente durante a aquisição dos PEATE.

c) Análise dos resultados: Os exames de PEATE foram analisados de duas formas, primeiramente considerando os possíveis resultados obtidos, que foram classificados em:

- Normal, quando todas as latências absolutas e interpicos estavam normais;

- Alterado condutivo, quando foi encontrado aumento das latências absolutas e latências interpicos normais, bem como alteração de orelha média demonstrada pela imitanciometria; 
- Alterado neural, quando além de aumento de latências absolutas, foram encontradas outras alterações como ausência de ondas e alterações das latências interpicos.

Numa segunda perspectiva, foram considerados cada parâmetro de análise do PEATE separadamente (valores das latências absolutas e das latências interpicos), classificando os resultados em três categorias:

- Normal, quando o valor da latência estava dentro dos padrões de normalidade;

- Aumentada, quando a latência estava aumentada em relação ao padrão normal;

- Ausente, quando não foi observada formação da onda, no caso da latência absoluta, ou quando não foi possível calcular o intervalo interpicos devido à ausência de alguma das ondas, no caso das latências interpicos.

Como parâmetro de normalidade para a análise das latências foram considerados os valores obtidos pela calibração biológica. A idade não foi uma variável considerada neste momento, uma vez que a criança de menor idade tinha 18 meses e, segundo a literatura (Hall e Mueller 1997, Hood 1998), a partir desta idade as latências obtidas são iguais às do adulto, pois a maturação das vias auditivas no nível do tronco encefálico está completa.. A diferença interaural normal considerada não pôde exceder a $0,4 \mathrm{~ms}$, pois valores maiores seriam indicativos de alteração central.

Após estes procedimentos, o exame foi registrado em papel, por meio de impressora. 


\subsubsection{AVALIAÇÕES COMPLEMENTARES}

\section{Audiometria tonal liminar e Logoaudiometria}

Este procedimento foi utilizado para avaliar a audição periférica por meio da obtenção de limiares auditivos, de 250 a $8000 \mathrm{~Hz}$ por via aérea e de 500 a $4000 \mathrm{~Hz}$ por via óssea, quando necessário.

Foi realizado no grupo HL quando possível, como exame audiológico complementar e no grupo C como critério de inclusão, não sendo possível sua aplicação no GH, pois esses pacientes se tratam dos casos com maiores comprometimentos e de menor idade.

Quando não foi possível realizar o exame completo, por falta de colaboração ou atenção da criança, foram priorizados os limiares de 500, 1000, 2000 e $4000 \mathrm{~Hz}$. O limite de normalidade dos limiares tonais considerado para indivíduos adultos foi de até $20 \mathrm{~dB}$ e, para crianças, até $15 \mathrm{~dB}$. A logoaudiometria foi composta por índice de reconhecimento de fala (IRF), utilizando lista de palavras monossílabas foneticamente balanceadas e limiar de reconhecimento de fala (SRT), com palavras dissílabas selecionadas aleatoriamente. O exame foi realizado em cabina acústica da marca VIBRASOM- Tecnologia acústica Ltda, em sala acusticamente preparada, utilizando audiômetro modelo SD-50 da marca Siemens, devidamente calibrado por pessoal qualificado.

\section{Avaliação neurológica e genética}

Todos os pacientes dos grupos $\mathrm{H}$ e $\mathrm{HL}$ foram avaliados por neurologista e geneticista, sendo realizados exame neurológico, neuroimagem e triagem molecular 
para os genes SHH, SIX3, GLI2, TGIF e PTCH. O exame de neuroimagem foi utilizado apenas para a definição do tipo de HPE. A classificação quanto à presença/ausência e tipo de mutação foi utilizada para a melhor caracterização da casuística. Ao todo, foram encontradas 12 mutações nos indivíduos estudados. Dos 13 pacientes do grupo $\mathrm{H}$, seis apresentaram mutações em genes HPE-determinantes, sendo três com mutações no SIX3, dois no SHH e um no GLI2. Dos 22 pacientes do grupo HL, outros seis apresentaram mutações, sendo quatro no gene SHH, um no GLI2 e um no PTCH.

\subsection{Análise dos resultados}

Os resultados obtidos foram analisados de duas formas: análise descritiva, por meio da obtenção e comparação de médias e desvios-padrão e análise por meio de testes estatísticos.

A análise estatística visou comparar os achados do PEATE, considerando como parâmetros as latências absolutas das ondas I, III e V e as latências interpicos I-V, III-V e I-III, comparadas entre os grupos experimentais e desses grupos com o controle.

Foram utilizados o Teste t de Student, a Análise de Variância (ANOVA), o Teste de Tukey e o Teste do Qui-quadrado.

O nível de significância adotado para a aplicação dos testes estatísticos deste estudo foi de $5 \%(\alpha=0,050)$, ou seja, quando a significância calculada (p) foi menor do que 5\% (0,050), encontramos uma diferença ou relação estatisticamente significante; quando a significância calculada (p) foi igual ou maior do que 5\% $(0,050)$ encontramos uma diferença ou relação estatisticamente não-significante.

Para análise dos dados foi utilizado o programa Statistica for Windows, versão 5.1, Statsoft Inc. 


\section{RESULTADOS}

Para melhor compreensão e maior clareza na explanação dos resultados, este capítulo foi divido em duas fases, de modo que inicialmente serão apresentados os resultados da etapa de calibração biológica e, em seguida, os resultados do PEATE nos grupos estudados.

$\mathrm{Na}$ segunda fase se encontra a descrição dos resultados de cada grupo separadamente e a comparação entre os grupos mediante análise estatística.

\subsection{FASE 1: DEFINIÇÃO DO PADRÃO DE NORMALIDADE DO PEATE}

Os indivíduos que fizeram parte deste grupo passaram por avaliação audiológica básica antes do PEATE, composta por audiometria e imitanciometria, para verificar a acuidade auditiva e as condições da orelha média. Todos os pacientes tiveram limiares audiométricos dentro da normalidade, bem como os resultados da timpanometria (curva tipo A) e dos reflexos acústicos (presentes em níveis de sensação normais), ou seja, apresentaram o perfil necessário para serem incluídos no estudo.

Os resultados obtidos no PEATE foram tabulados (Anexo 4) e analisados por meio de estatística descritiva, ou seja, a média e o desvio-padrão das latências de cada onda (I, III e V) e das latências interpicos (I-V, III-V e I-III).

Após a análise estatística dos dados descritos acima, foram obtidos os valores para o PEATE (latências - em milissegundos - mínima e máxima, respectivamente, para os gêneros feminino e masculino) descritos na Tabela 2. 
TABELA 2 - Valores mínimos e máximos obtidos pelas médias e desvios-padrão das latências dos indivíduos normais, para os gêneros feminino e masculino.

\begin{tabular}{ccc}
\hline & Feminino & Masculino \\
\hline I & $1,8-2,0$ & $1,8-2,0$ \\
\hline III & $3,8-4,0$ & $3,9-4,1$ \\
\hline $\mathbf{V}$ & $5,7-5,9$ & $5,8-6,1$ \\
\hline I-V & $3,8-4,0$ & $4,0-4,2$ \\
\hline III-V & $1,8-2,0$ & $1,9-2,1$ \\
\hline I-III & $1,9-2,1$ & $2,0-2,2$ \\
\hline
\end{tabular}

Os valores descritos acima foram, então, considerados como padrão de normalidade para o PEATE, ao qual os resultados dos demais indivíduos da casuística deste estudo foram comparados.

\subsection{FASE 2: RESULTADOS DO PEATE NOS GRUPOS ESTUDADOS}

\subsubsection{CARACTERIZAÇÃO DOS GRUPOS}

Os indivíduos estudados foram designados por números, a fim de preservar sua identidade. Suas características consideradas importantes para o estudo (gênero, idade, mutação genética, tipo de HPE e presença de queixa auditiva) foram tabuladas e estão descritas nos Anexos 5 e 6. 
- Idade

A faixa etária dos pacientes foi variável, abrangendo de 1 ano e 6 meses a 22 anos de idade (ou 18 a 264 meses). A média etária (em meses) foi de 45 no GH, 116 no GHL e 102 no GC, como representado no Gráfico 1.

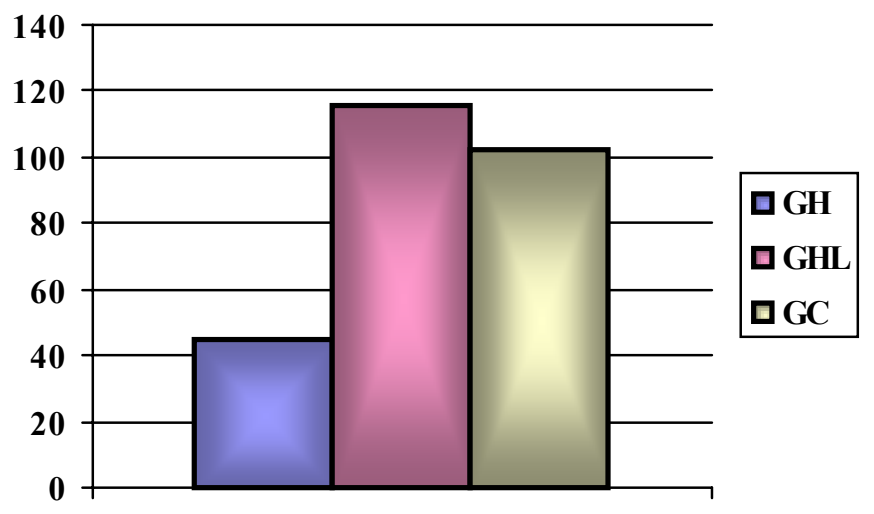

GRÁFICO 1 - Comparação das médias etárias, em meses, nos grupos GH (HPE clássica), GHL (HPE-like) e GC (controle).

Podemos observar que os pacientes de menor faixa etária eram do GH e os de maior pertenciam ao GHL.

\section{- Gênero}

Com relação ao gênero, dos 13 indivíduos do $\mathrm{GH}, 8$ (62\%) eram do gênero feminino e 5 (38\%) do gênero masculino; dos 22 indivíduos do GHL, 17 (77\%) eram do gênero feminino e 5 (23\%) do gênero masculino; dos 22 indivíduos do GC, 15 (68\%) eram do gênero feminino e 7 (32\%) do gênero masculino, conforme representado no Gráfico 2. 


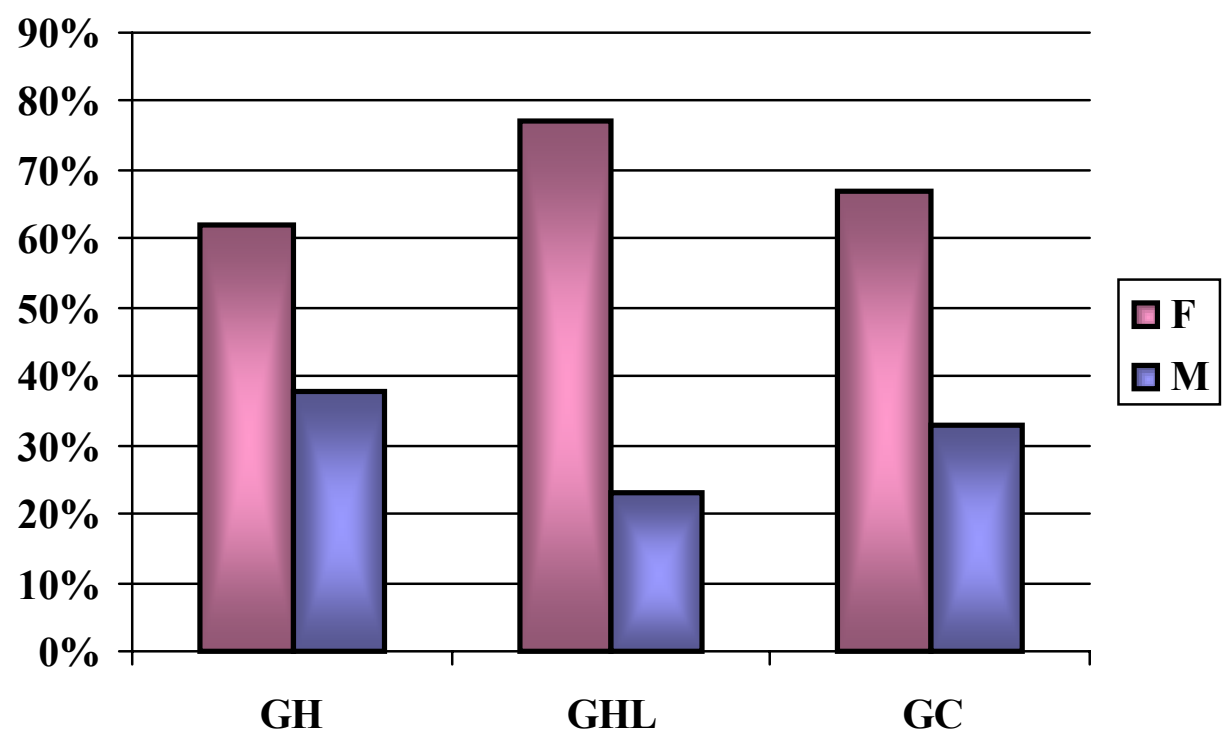

Legenda: $\mathrm{F}=$ feminino; $\mathrm{M}=$ masculino

GRÁFICO 2 - Distribuição dos indivíduos dos grupos H, HL e C quanto ao gênero.

Comparando-se os três grupos estudados em relação ao gênero, observamos uma predominância do feminino sobre o masculino em todos os grupos, mais evidente no GHL.

\section{- Tipo de HPE}

Quanto ao tipo de HPE, variável pertinente apenas aos 13 indivíduos do GH, 7 indivíduos possuíam do tipo alobar (54\%), 4 o tipo semilobar (31\%) e 2 o tipo lobar (15\%), como podemos visualizar no Gráfico 3. 


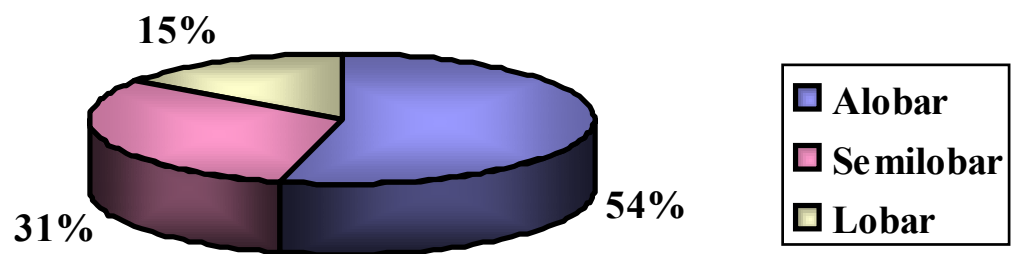

GRÁFICO 3 - Distribuição dos indivíduos do GH quanto ao tipo de HPE.

Podemos observar que a maioria dos indivíduos do GH (54\%) apresentou o tipo alobar, ou seja, a forma mais grave de HPE.

\section{- Mutações Genéticas}

As mutações genéticas estavam presentes em 6 indivíduos do $\mathrm{GH}$ e outros 6 do GHL, correspondendo a $46 \%$ e $18 \%$ das amostras do GH e do GHL respectivamente.

No GH, 3 indivíduos apresentaram mutação no gene SIX3 (23\%), 2 no gene SHH (15\%) e 1 no GLI2 (8\%). No GHL, 4 apresentaram mutação no gene SHH (18\%),1 no gene GLI2 (5\%) e 1 no gene PTCH (5\%). Podemos visualizar essa distribuição do Gráfico 4. 


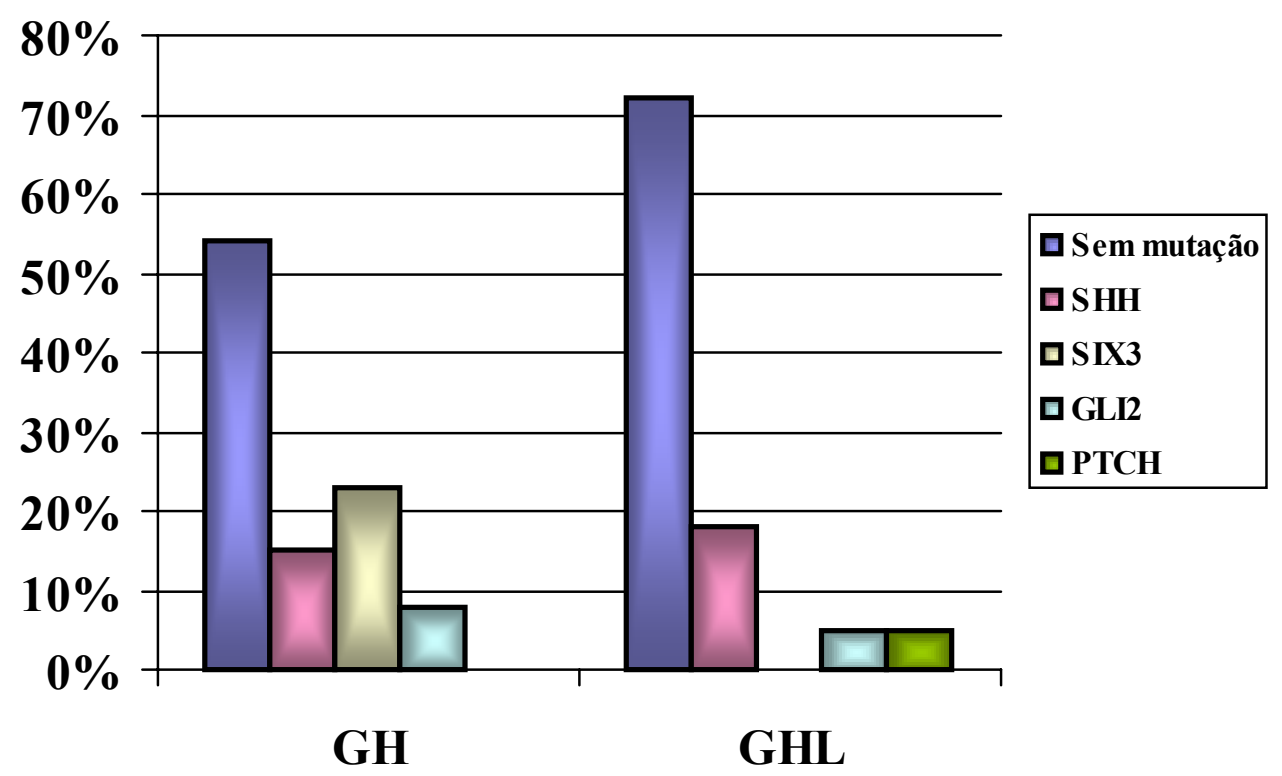

GRÁFICO 4 - Distribuição dos indivíduos do GH e do GHL quanto às mutações.

Observamos que, em ambos os grupos, existiram mais indivíduos sem mutações detectadas do que indivíduos com mutação definida em algum gene. No GH predominaram as mutações do gene SIX3 e no GHL as mutações no SHH.

\subsubsection{PROCEDIMENTOS PRÉVIOS}

\subsubsection{Anamnese}

Em relação à anamnese audiológica, os relatos dos pais ou responsáveis foram classificados em 3 categorias: 1- Ausência de queixa auditiva, quando não havia relato atual ou pregresso de infecções otológicas ou de acuidade auditiva reduzida; 2- Presença de queixa auditiva, quando foi relatado história de otites de repetição concomitante com diminuição da acuidade auditiva; e 3- Dúvidas quanto à audição, quando não havia queixa de otites, mas sim dúvidas relacionadas apenas à acuidade auditiva. 
Dos 13 pais ou responsáveis do GH, 6 (46\%) se enquadraram na categoria 1 , considerados sem queixa auditiva; $5(38 \%)$ na categoria 2 , com queixa auditiva e 2 $(16 \%)$ na categoria 3, apresentando dúvidas quanto à audição, 4. Dos 22 pais ou responsáveis do GHL, apenas $2(10 \%)$ referiram queixa auditiva e os demais 20 (90\%) negaram qualquer queixa auditiva. No GC, não houve queixa auditiva. Podemos observar essa distribuição no Gráfico 5.

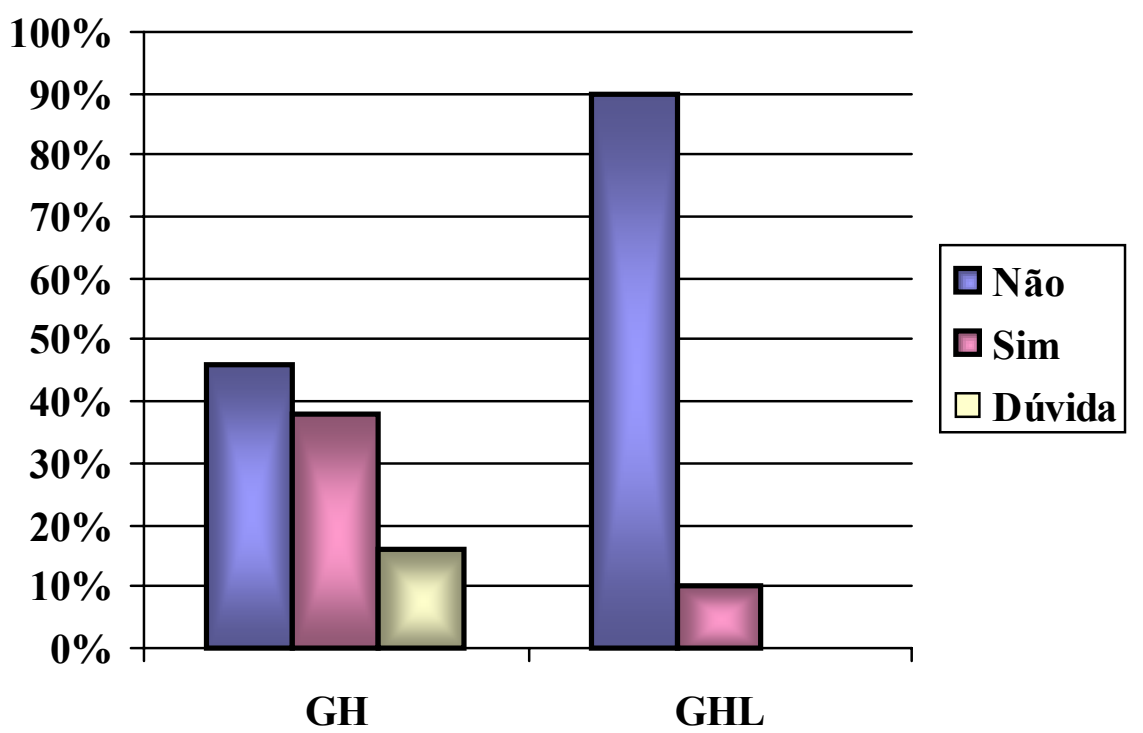

GRÁFICO 5 - Distribuição dos indivíduos dos grupos H e HL quanto aos dados da anamnese (presença de queixa auditiva).

Quando consideramos os resultados da anamnese, ou seja, a presença de queixa auditiva, verificamos que os pais dos pacientes do $\mathrm{GH}$ apresentaram mais queixas auditivas do que os pais dos pacientes do GHL.

\subsubsection{Audiometria}

A audiometria, procedimento complementar para os indivíduos do GHL e critério de inclusão para os do GC, foi realizada apenas nos pacientes que colaboraram e tinham idade suficiente para responder de forma consistente ao teste. No GH, nenhum 
paciente apresentou condições para responder ao teste devido ao comprometimento neuropsicomotor importante e à baixa idade.

No GHL, 18 pacientes realizaram a ATL e os demais 4 não colaboraram. Considerando as 36 orelhas dos pacientes testados, 11 orelhas $(30 \%)$ tiveram alteração compatível com perda auditiva do tipo condutiva, de grau leve. As demais orelhas (70\%) tiveram resultados dentro da normalidade.

No GC, 4 pacientes não realizaram o exame, pois tinham idades entre 18 e 24 meses, e não puderam responder ao teste. Dentre aqueles que responderam ao teste, todos $(100 \%)$ apresentaram limiares auditivos dentro da normalidade, ou seja, até 20 ou $15 \mathrm{~dB}$ para adulto e criança, respectivamente.

Os resultados da ATL e da logoaudiometria estão tabulados nos Anexos 7 e 8 para os grupos HL e C, respectivamente.

\subsubsection{Imitanciometria}

A imitanciometria foi realizada em todos os pacientes. Para a análise foram considerados a timpanometria (tipo de curva obtida: A, Ar, Ad, B ou C) e a pesquisa dos reflexos acústicos (reflexos contra e ipsilaterais das duas orelhas foram classificados em presentes ou ausentes).

$\mathrm{Na}$ timpanometria, o GH apresentou alta ocorrência de curva tipo $\mathrm{B}$, revelando a presença de alteração de orelha média em $47 \%$ das orelhas testadas. Considerando as 26 orelhas, apenas $4(15 \%)$ tiveram curva timpanométrica normal, ou seja, tipo A. As demais foram do tipo $\operatorname{Ar}(12 \%)$ e do tipo C (26\%).

No GHL, verificamos que a maioria das 44 orelhas avaliadas apresentou curva tipo A, revelando integridade da orelha média em $52 \%$ das orelhas. Foi obtida curva tipo Ad em $16 \%$, tipo B em 9\% e tipo C em $23 \%$ das orelhas. 
No GC, todos os pacientes apresentaram curva tipo A bilateralmente, confirmando a ausência de alterações de orelha média. Podemos visualizar essa distribuição no Gráfico 6.

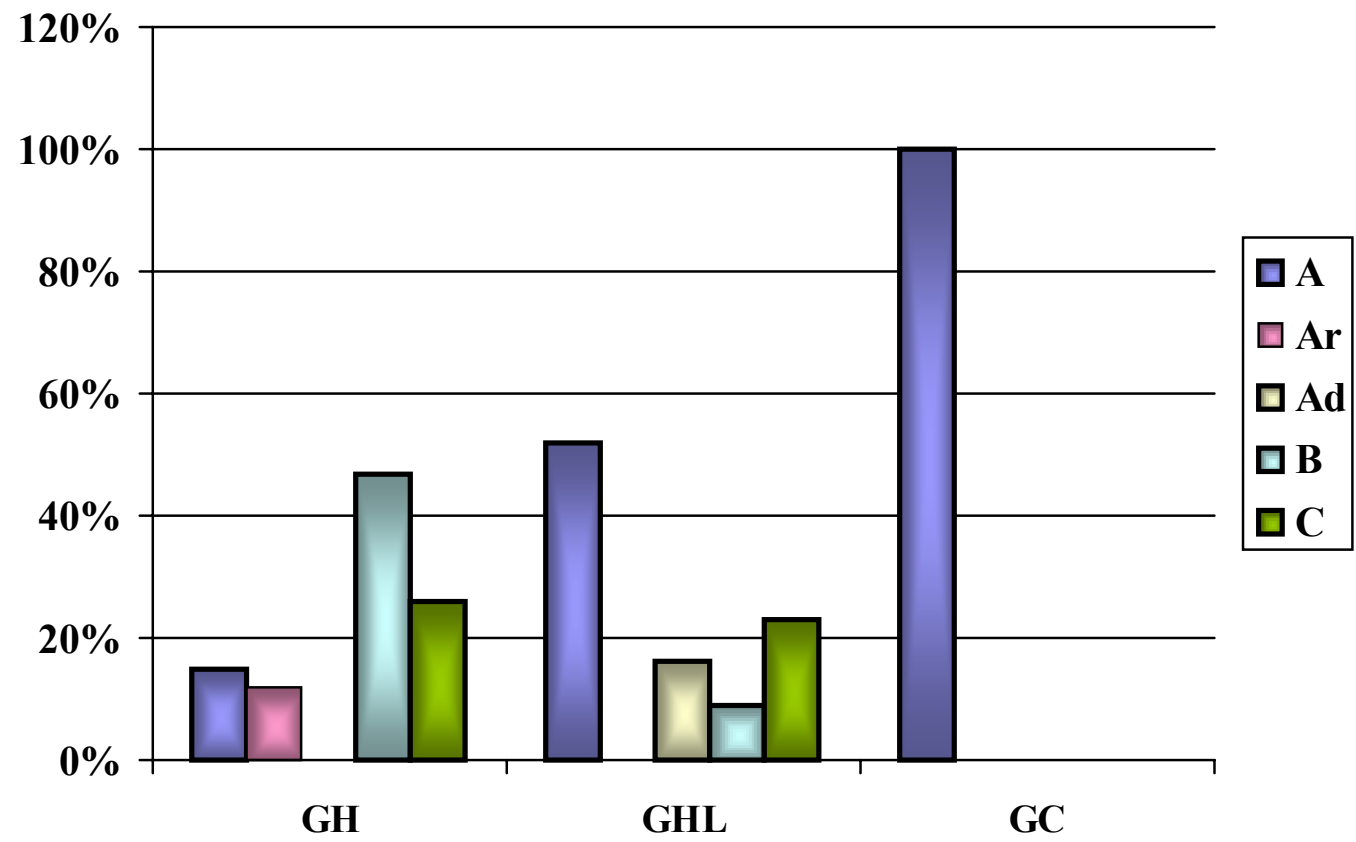

GRÁFICO 6 - Tipo de curva timpanométrica encontrada nas orelhas dos pacientes dos grupos $\mathrm{H}$, HL e C.

A pesquisa do reflexo acústico foi realizada em 8 pacientes do GH, ou seja, 16 orelhas, correspondendo a $63 \%$, uma vez que os demais (37\%) não colaboraram para tal procedimento. Dessas orelhas, 12 (47 \%) tiveram ausência de reflexos ipsi e contralaterais, e $4(16 \%)$ tiveram reflexos presentes.

No GHL, obtivemos reflexos ausentes em 9 orelhas (20\%), e nas demais 35 (80\%) foram obtidos os reflexos normalmente.

No GC todos os pacientes apresentaram reflexos normais, conforme podemos visualizar no Gráfico 7. 


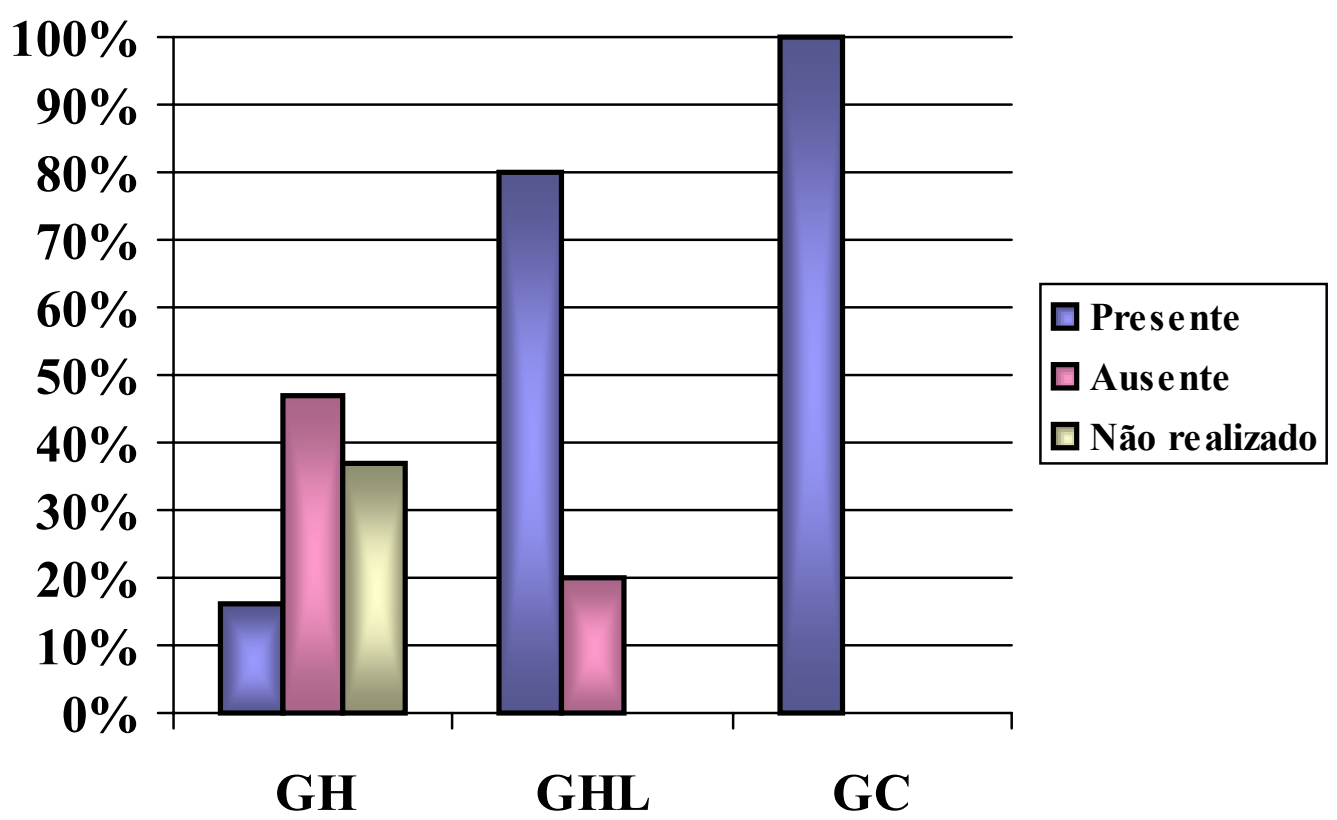

GRÁFICO 7 - Resultados da pesquisa do reflexo acústico nos grupos H, HL e C.

Os resultados da imitanciometria estão tabulados nos Anexos 9 e 10 para os grupos $\mathrm{H}$, HL respectivamente.

\subsubsection{PEATE}

Os resultados do PEATE, procedimento principal deste estudo, serão descritos nos parágrafos a seguir, separadamente em cada grupo, devido à diversidade de achados e peculiaridade dos pacientes.

Serão apresentados primeiramente os resultados do GC, tendo em vista que estes serão referência para a análise dos resultados dos demais grupos, GH e GHL. 


\subsubsection{Descrição dos resultados referentes ao Grupo Controle (GC)}

Os resultados dos PEATE deste grupo, comparados ao padrão de normalidade, foram todos considerados normais e houve $100 \%$ de presença de ondas. Esses resultados foram submetidos a análise por meio de estatística descritiva. Os valores mínimos, máximos, as médias e os desvios-padrão das latências absolutas e interpicos, por orelha, podem ser visualizadas na Tabela 3. A distribuição individual dos valores em cada uma das medidas pode ser visualizada no Anexo 13.

TABELA 3- Valores mínimos, máximos, médias e desvios-padrão das latências absolutas e interpicos, por orelha, no $\mathbf{~ G C}$, considerando $\mathbf{n}=\mathbf{2 2}$.

\begin{tabular}{|c|c|c|c|c|c|}
\hline Lado & Variáveis & Mínimo & Máximo & Média & Desvio-padrão \\
\hline \multirow{6}{*}{ 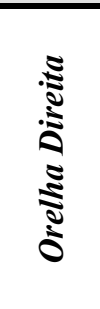 } & I & 1,8 & 2,0 & 1,92 & 0,070 \\
\hline & III & 3,8 & 4,1 & 3,97 & 0,103 \\
\hline & $\mathbf{V}$ & 5,8 & 6,1 & 5,90 & 0,102 \\
\hline & I-V & 3,8 & 4,2 & 3,97 & 0,110 \\
\hline & III-V & 1,8 & 2,0 & 1,92 & 0,055 \\
\hline & I-III & 1,9 & 2,2 & 2,04 & 0,100 \\
\hline \multirow{6}{*}{ 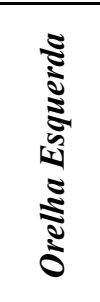 } & I & 1,8 & 2,0 & 1,91 & 0,079 \\
\hline & III & 3,8 & 4,1 & 3,94 & 0,101 \\
\hline & $\mathbf{V}$ & 5,8 & 6,1 & 5,90 & 0,109 \\
\hline & I-V & 3,8 & 4,2 & 3,97 & 0,115 \\
\hline & III-V & 1,8 & 2,1 & 1,95 & 0,066 \\
\hline & I-III & 1,8 & 2,2 & 2,01 & 0,100 \\
\hline \multicolumn{2}{|c|}{ Dif. i.a. $\mathrm{V}$} & 0 & 0,1 & 0,03 & 0,047 \\
\hline
\end{tabular}

5.2.3.2 Descrição dos resultados referentes ao Grupo com Holoprosencefalia Clássica (GH)

Os achados do PEATE no GH foram heterogêneos, de modo que a simples comparação estatística por meio da aplicação de testes poderia ocultar os achados 
individuais, mascarando a heterogeneidade de achados. Assim, os resultados nesse grupo foram descritos primeiramente pelos achados do PEATE, que foram classificados em normal, alterado condutivo e alterado neural; e posteriormente pelos valores das latências absolutas e interpicos.

\section{Resultados da avaliação do PEATE}

Constatamos a presença das três categorias possíveis de resultados: normal, alterado condutivo e alterado neural, inclusive com ausência de ondas.

Assim, no GH houve apenas 1 paciente com resultado normal, correspondendo a $8 \%$ da amostra; 4 pacientes com alteração condutiva (30\%) e 8 pacientes com resultados alterados (62\%). Podemos observar essa distribuição no Gráfico 8.

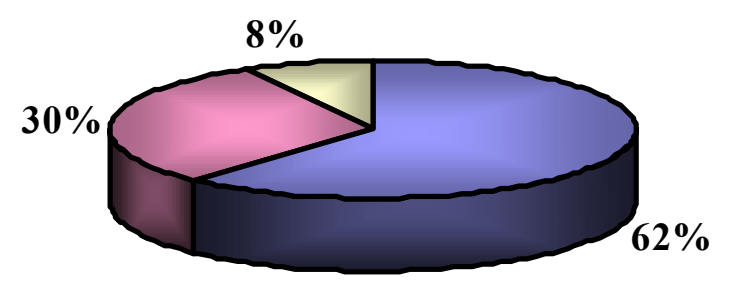

$\square$ Alterados neurais
$\square$ Alterados condutivos
$\square$ Normais

GRÁFICO 8 - Classificação dos resultados do PEATE no GH.

Os resultados individuais das latências absolutas e interpicos de todas as ondas, de todos os 13 pacientes encontram-se no Anexo 11. 
O paciente $5(1 / 13)$, correspondendo a $7,7 \%$ do $\mathrm{GH}$, foi o único neste grupo que apresentou resultado do PEATE dentro dos padrões de normalidade

Os pacientes 1, 3, 6 e 12 (4/13), correspondendo a 30,8\% do GH, apresentaram latências absolutas das ondas I, III e V aumentadas bilateralmente e latências interpicos todas normais. Esses mesmos pacientes apresentaram alterações timpanométricas, sugerindo comprometimento de orelha média. Estes achados permitiram classificar os resultados como alterados condutivos, evidenciando que o atraso de latências absolutas ocorreu por problema periférico, não neural.

Os pacientes $2,4,7,8,9,10,11$ e 13 (8/13), correspondendo a 61,5\% do $\mathrm{GH}$, apresentaram resultados alterados, que serão descritos separadamente, devido à heterogeneidade de alterações:

O paciente 2 apresentou latências absolutas das ondas I, III e V aumentadas bilateralmente e latência interpicos III-V aumentada bilateralmente. Os interpicos I-V e I-III mostraram-se normais.

O paciente 4 apresentou latências absolutas da onda I normais e das ondas III e $\mathrm{V}$ aumentadas bilateramente. Os interpicos I-V, III-V e I-III mostraram-se aumentados bilateralmente.

O paciente 7 apresentou latências absolutas das ondas I e III normais do lado direito e aumentadas do lado esquerdo, com onda $\mathrm{V}$ ausente bilateralmente. $\mathrm{O}$ interpico I-III estava normal à direita e aumentado à esquerda e os demais interpicos não puderam ser calculados pela ausência da onda V.

O paciente 8 apresentou latências absolutas das ondas I, III e $\mathrm{V}$ normais. $\mathrm{O}$ interpico I-V mostrou-se aumentado bilateralmente, o III-V aumentado à direita e normal à esquerda e o I-III aumentado à esquerda e normal à direita. Apesar de as 
latências absolutas estarem normais, houve aumento de interpicos pois algumas das latências absolutas estavam no limite mínimo da normalidade e outras no limite máximo.

O paciente 9 apresentou latências absolutas das ondas I, III e V e latências interpicos aumentadas, exceto interpicos I-III bilateral.

O paciente 10 apresentou latências absolutas das ondas I, III e V à direita e da onda III à esquerda aumentadas. A onda I estava normal e a onda V ausente à esquerda. Os interpicos do lado direito I-V e I-III mostraram-se normais e o III-V aumentado. À esquerda, o interpicos I-III estava normal e os demais interpicos desse lado não puderam ser calculados pela ausência de onda $\mathrm{V}$.

O paciente 11 apresentou latências absolutas das ondas I, III e V e todas as latências interpicos aumentadas bilateralmente.

O paciente 13 apresentou latências absolutas da onda I normais e da onda III aumentadas bilateralmente. A onda V estava ausente e os interpicos I-III aumentados bilateralmente.

Mesmo com a diversidade de resultados do PEATE no $\mathrm{GH}$, estes foram submetidos a análise por meio de estatística descritiva e apresentamos na Tabela 4 os valores médios, mínimos, máximos e desvios-padrão para as latências absolutas e interpicos por orelha, separadamente. 
TABELA 4- Distribuição dos valores mínimos, máximos, médios e desvios-padrão do GH e as médias e desvios-padrão das latências absolutas e interpicos do GC, por orelha.

\begin{tabular}{|c|c|c|c|c|c|c|c|c|}
\hline \multirow{2}{*}{ Lado } & \multirow{2}{*}{ Variáveis } & \multicolumn{5}{|c|}{ GH } & \multicolumn{2}{|c|}{$\overline{G C}$} \\
\hline & & $\mathbf{N}$ & Mínimo & Máximo & Média & DP & Média & DP \\
\hline \multirow{6}{*}{ 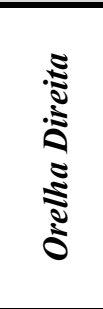 } & I & 13 & 1,8 & 2,6 & 2,21 & 0,254 & 1,92 & 0,070 \\
\hline & III & 13 & 3,8 & 5,0 & 4,35 & 0,304 & 3,97 & 0,103 \\
\hline & $\mathbf{V}$ & 11 & 5,9 & 7,4 & 6,47 & 0,424 & 5,90 & 0,102 \\
\hline & I-V & 11 & 3,8 & 5,4 & 4,20 & 0,454 & 3,97 & 0,110 \\
\hline & III-V & 11 & 1,9 & 3,5 & 2,24 & 0,443 & 1,92 & 0,055 \\
\hline & I-III & 13 & 1,9 & 3,0 & 2,14 & 0,317 & 2,04 & 0,100 \\
\hline \multirow{6}{*}{ 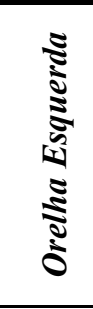 } & I & 13 & 1,8 & 2,6 & 2,19 & 0,275 & 1,91 & 0,079 \\
\hline & III & 13 & 4,0 & 5,7 & 4,52 & 0,510 & 3,94 & 0,101 \\
\hline & $\mathbf{V}$ & 10 & 5,9 & 7,5 & 6,51 & 0,525 & 5,90 & 0,109 \\
\hline & I-V & 10 & 3,8 & 5,5 & 4,24 & 0,505 & 3,97 & 0,115 \\
\hline & III-V & 10 & 1,9 & 2,3 & 2,07 & 0,141 & 1,95 & 0,066 \\
\hline & I-III & 13 & 1,8 & 3,9 & 2,33 & 0,604 & 2,01 & 0,100 \\
\hline & $V$ i.a. & 10 & 0 & 0,5 & 0,13 & 0,149 & 0,03 & 0,047 \\
\hline
\end{tabular}

\section{Descrição dos valores das latências absolutas e interpicos no GH}

A Onda I apresentou latência normal em 9 orelhas (35\%) e aumentada em 17 (65\%); a Onda III estava normal em 3 orelhas (12\%) e aumentada em 23 (88\%); a Onda $\mathrm{V}$ foi normal em 3 orelhas (12\%), aumentada em 18 (69\%) e ausente em 5 (19\%). Quanto aos interpicos, o I-V foi normal em 13 orelhas (50\%), aumentado em 8 (31\%) e ausente em 5 (19\%); o III-V foi normal em 11 orelhas (43\%), aumentado em 10 (38\%) e ausente em 5 (19\%) e o I-III foi normal em 17 orelhas (65\%) e aumentado em 9 (35\%). Podemos visualizar essa distribuição no Gráfico 9. 


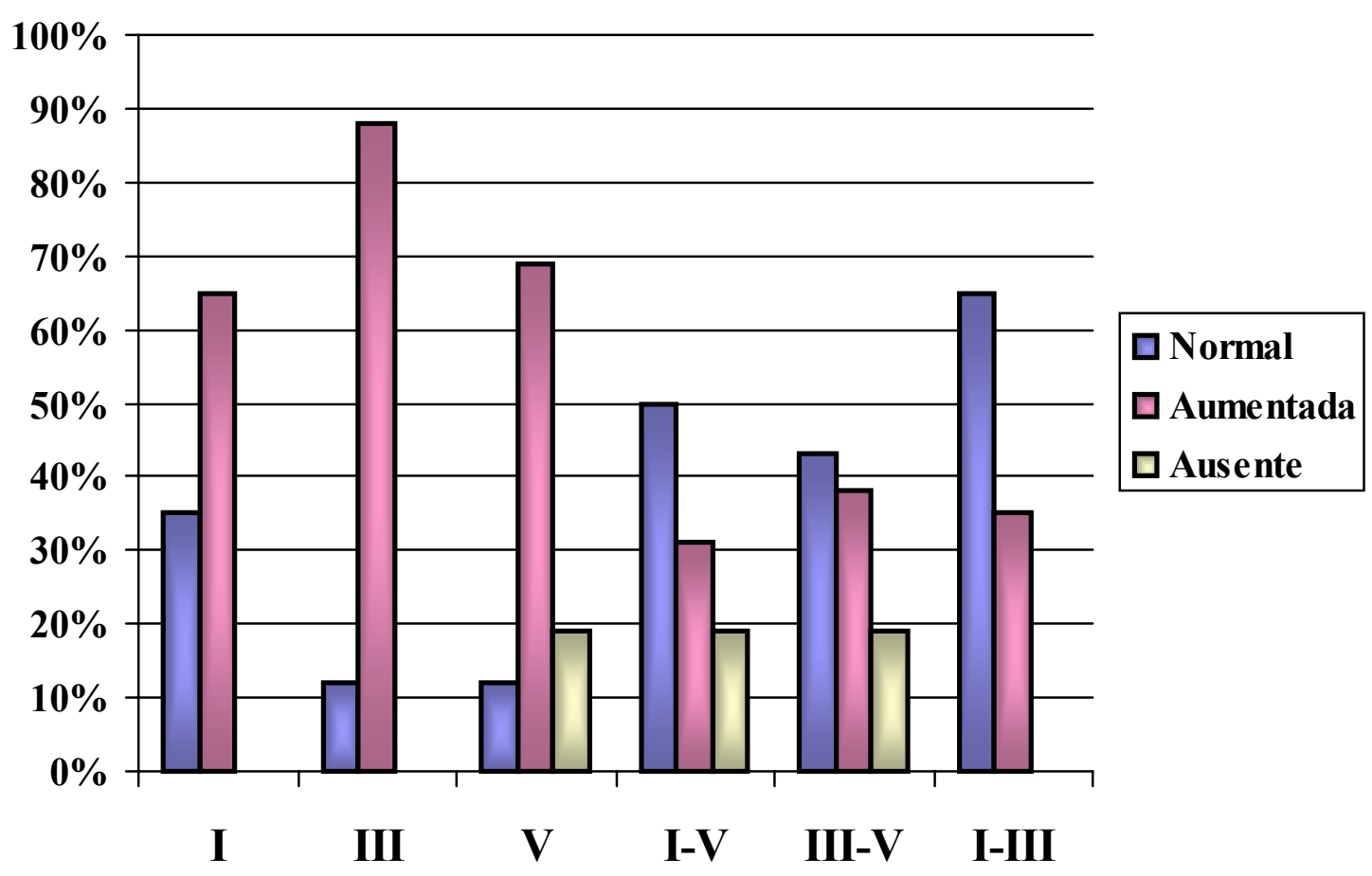

GRÁFICO 9 - Resultados da análise das latências absolutas das ondas I, III e V e interpicos I-V, III-V e I-III do PEATE no GH.

Para comparar as porcentagens de resultados normais e alterados entre $\mathrm{GH}$ e GC, e entre GH e GHL, foi realizado o teste do Qui-quadrado de associação.

Comparando o GH com o GC, encontramos resultados semelhantes à comparação do GH com o GHL, ou seja, o grupo GH destoou dos demais, que por sua vez tiveram resultados semelhantes entre si. Nessas comparações, todas as variáveis tiveram diferença estatisticamente significante, como podemos visualizar nas Tabelas 5, $6,7,8,9$ e 10.

Nestas tabelas, estão descritos os valores do Qui-quadrado $\left(\mathrm{X}^{2}\right)$, Graus de Liberdade (g.1.) e significância (p).

Os valores estatisticamente significantes estão marcados com asterisco (*). 
TABELA 5 - Comparação da análise da latência absoluta da onda I entre GH e GC por meio do teste do Qui-quadrado.

\begin{tabular}{|c|c|c|}
\hline & GH & GC \\
\hline Normal & 9 & 44 \\
\hline Aumentada & 17 & 0 \\
\hline$X^{2}=37.99$ & g.l. $=1$ & $\mathrm{p}<0,0001^{*}$ \\
\hline
\end{tabular}

TABELA 6 - Comparação da análise da latência absoluta da onda III entre GH e GC por meio do teste do Qui-quadrado.

\begin{tabular}{llc}
\hline & GH & GC \\
\hline Normal & $\mathbf{3}$ & 44 \\
\hline Aumentada & $\mathbf{2 3}$ & 0 \\
\hline $\mathbf{X}^{\mathbf{2}=\mathbf{5 7 . 9 7}}$ & g.l. $=\mathbf{1}$ & $\mathrm{p}<0,0001^{*}$ \\
\hline
\end{tabular}

TABELA 7 - Comparação da análise da latência absoluta da onda V entre GH e GC por meio do teste do Qui-quadrado.

\begin{tabular}{llc}
\hline & GH & GC \\
\hline Normal & $\mathbf{3}$ & 44 \\
\hline Aumentado & $\mathbf{1 8}$ & 0 \\
\hline Ausente & $\mathbf{5}$ & 0 \\
\hline $\mathbf{X}^{2}=\mathbf{5 7 . 9 7}$ & g.l. $=\mathbf{2}$ & $\mathrm{p}<0,0001^{*}$ \\
\hline
\end{tabular}

TABELA 8- Comparação da análise da latência interpicos I-V entre GH e GC por meio do teste do Qui-quadrado.

\begin{tabular}{llc}
\hline & GH & GC \\
\hline Normal & $\mathbf{1 3}$ & 44 \\
\hline Aumentado & $\mathbf{8}$ & 0 \\
\hline Ausente & $\mathbf{5}$ & 0 \\
\hline $\mathbf{X}^{\mathbf{2}=\mathbf{2 7 , 0 1}}$ & g.l.=2 & $\mathrm{p}<0,0001^{*}$ \\
\hline
\end{tabular}

TABELA 9 - Comparação da análise da latência interpicos III-V entre GH e GC por meio do teste do Qui-quadrado. 


\begin{tabular}{llc}
\hline & GH & GC \\
\hline Normal & $\mathbf{1 1}$ & 44 \\
\hline Aumentado & $\mathbf{1 0}$ & 0 \\
\hline Ausente & $\mathbf{5}$ & 0 \\
\hline $\mathbf{X}^{\mathbf{2}=\mathbf{3 2 , 3 0}}$ & $\mathbf{g . l} \mathbf{l}=\mathbf{2}$ & $\mathrm{p}<0,0001^{*}$ \\
\hline
\end{tabular}

TABELA 10 - Comparação da análise da latência interpicos I-III entre GH e GC por meio do teste do Qui-quadrado.

\begin{tabular}{llc}
\hline & GH & GC \\
\hline Normal & $\mathbf{1 7}$ & 44 \\
\hline Aumentado & $\mathbf{9}$ & 0 \\
\hline $\mathbf{X}^{\mathbf{2}=\mathbf{1 7 , 4 7}}$ & g.l. $=\mathbf{1}$ & $\mathrm{p}<0,0001^{*}$ \\
\hline
\end{tabular}

Como já descrito anteriormente, todas as variáveis tiveram diferença estatisticamente significante entre o GH e o GHL, com $p<0,0001$, sendo que no GH houve um número maior de latências aumentadas comparado ao GHL. Podemos visualizar os valores do Qui-quadrado $\left(\mathrm{X}^{2}\right)$, Graus de Liberdade (g.l.) e significância (p) da comparação entre GH e GHL nas Tabelas 11 12, 13, 14, 15 e 16 abaixo. Os valores estatisticamente significantes estão marcados com asterisco (*).

TABELA 11 - Comparação da análise da latência absoluta da onda I entre GH e GHL por meio do teste do Qui-quadrado.

\begin{tabular}{llc}
\hline & GH & GHL \\
\hline Normal & $\mathbf{9}$ & 37 \\
\hline Aumentada & $\mathbf{1 7}$ & 7 \\
\hline $\mathbf{X}^{2}=\mathbf{1 7 , 7 5}$ & g.l.= & $\mathrm{p}<0,0001^{*}$ \\
\hline
\end{tabular}

TABELA 12 - Comparação da análise da latência absoluta da onda III entre GH e GHL por meio do teste do Qui-quadrado. 


\begin{tabular}{llc}
\hline & GH & GHL \\
\hline Normal & $\mathbf{3}$ & 37 \\
\hline Aumentada & $\mathbf{2 3}$ & 7 \\
\hline $\mathbf{X}^{\mathbf{2}=\mathbf{3 5 , 1 2}}$ & g.l. $=\mathbf{1}$ & $\mathrm{p}<0,0001^{*}$ \\
\hline
\end{tabular}

TABELA 13 - Comparação da análise da latência absoluta da onda V entre GH e GHL por meio do teste do Qui-quadrado.

\begin{tabular}{llc}
\hline & GH & GHL \\
\hline Normal & $\mathbf{3}$ & 37 \\
\hline Aumentado & $\mathbf{1 8}$ & 7 \\
\hline Ausente & $\mathbf{5}$ & 0 \\
\hline $\mathbf{X}^{\mathbf{2}=\mathbf{3 6 , 5 2}}$ & g.l. $=\mathbf{2}$ & $\mathrm{p}<0,0001^{*}$ \\
\hline
\end{tabular}

TABELA 14 - Comparação da análise da latência interpicos I-V entre GH e GHL por meio do teste do Qui-quadrado.

\begin{tabular}{llc}
\hline & GH & GHL \\
\hline Normal & $\mathbf{1 3}$ & 44 \\
\hline Aumentado & $\mathbf{8}$ & 0 \\
\hline Ausente & $\mathbf{5}$ & 0 \\
\hline $\mathbf{X}^{2}=\mathbf{2 7 , 0 1}$ & g.l. $=\mathbf{2}$ & $\mathrm{p}<0,0001^{*}$ \\
\hline
\end{tabular}

TABELA 15 - Comparação da análise da latência interpicos III-V entre GH e GHL por meio do teste do Qui-quadrado.

\begin{tabular}{llc}
\hline & GH & GHL \\
\hline Normal & $\mathbf{1 1}$ & 44 \\
\hline Aumentado & $\mathbf{1 0}$ & 0 \\
\hline Ausente & $\mathbf{5}$ & 0 \\
\hline $\mathbf{X}^{2}=\mathbf{3 2 , 3 0}$ & $\mathbf{g . l} \mathbf{=}=\mathbf{2}$ & $\mathrm{p}<0,0001^{*}$ \\
\hline
\end{tabular}

TABELA 16 - Comparação da análise da latência interpicos I-III entre GH e GHL por meio do teste do Qui-quadrado.

\begin{tabular}{llc}
\hline & GH & GHL \\
\hline Normal & $\mathbf{1 7}$ & 44 \\
\hline Aumentado & $\mathbf{9}$ & 0 \\
\hline $\mathbf{X}^{\mathbf{2}=\mathbf{1 7 , 4 7}}$ & $\mathbf{g . l .}=\mathbf{1}$ & $\mathrm{p}<0,0001^{*}$ \\
\hline
\end{tabular}




\subsubsection{Descrição dos resultados referentes ao Grupo com HPE-like (GHL)}

Neste grupo, não foram encontradas alterações no PEATE sugestivas de alteração na condução neural. As únicas alterações encontradas foram atribuídas a perdas auditivas condutivas, uma vez que consistiam unicamente do aumento das latências absolutas das ondas I, III e $\mathrm{V}$ com intervalos interpicos normais. Esse resultado foi encontrado em 7 das 44 orelhas testadas, perfazendo $16 \%$ do total.

A maioria dos resultados estava dentro dos padrões de normalidade. Os resultados do PEATE (latências em milissegundos) estão no Anexo 12.

Esses resultados foram submetidos a análise por meio de estatística descritiva. Na Tabela 17 abaixo estão os valores de média e desvio-padrão para cada variável analisada no GHL.

TABELA 17- Distribuição dos valores mínimos, máximos, médios e desvios-padrão do GHL e as médias e desvios-padrão das latências absolutas e interpicos do GC, por orelha.

\begin{tabular}{|c|c|c|c|c|c|c|c|c|}
\hline \multirow{2}{*}{ Lado } & \multirow{2}{*}{ Variáveis } & \multicolumn{5}{|c|}{ GHL } & \multicolumn{2}{|c|}{ GC } \\
\hline & & $\mathbf{N}$ & Mínimo & Máximo & Média & DP & Média & DP \\
\hline \multirow{6}{*}{ 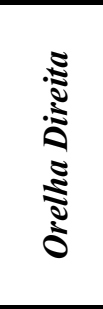 } & I & 22 & 1,8 & 2,8 & 1,99 & 0,221 & 1,92 & 0,070 \\
\hline & III & 22 & 3,7 & 4,8 & 4,04 & 0,230 & 3,97 & 0,103 \\
\hline & $\mathbf{V}$ & 22 & 5,7 & 6,6 & 5,95 & 0,221 & 5,90 & 0,102 \\
\hline & I-V & 22 & 3,8 & 4,1 & 3,94 & 0,096 & 3,97 & 0,110 \\
\hline & III-V & 22 & 1,8 & 2,1 & 1,91 & 0,088 & 1,92 & 0,055 \\
\hline & I-III & 22 & 1,9 & 2,2 & 2,03 & 0,078 & 2,04 & 0,100 \\
\hline \multirow{6}{*}{ 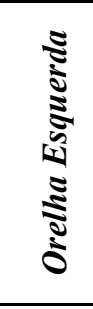 } & I & 22 & 1,8 & 2,8 & 2,01 & 0,225 & 1,91 & 0,079 \\
\hline & III & 22 & 3,8 & 4,9 & 4,04 & 0,238 & 3,94 & 0,101 \\
\hline & $\mathbf{V}$ & 22 & 5,7 & 6,8 & 5,94 & 0,253 & 5,90 & 0,109 \\
\hline & I-V & 22 & 3,8 & 4,1 & 3,92 & 0,093 & 3,97 & 0,115 \\
\hline & III-V & 22 & 1,8 & 2,1 & 1,90 & 0,092 & 1,95 & 0,066 \\
\hline & I-III & 22 & 1,8 & 2,2 & 2,01 & 0,095 & 2,01 & 0,100 \\
\hline & $V$ i.a. & 22 & 0 & 0,2 & 0,06 & 0,064 & 0,03 & 0,047 \\
\hline
\end{tabular}


Considerando cada parâmetro de análise do PEATE separadamente (valores das latências absolutas e das latências interpicos) para as 44 orelhas testadas no GHL, classificamos os resultados em duas categorias:

- Normal, quando o valor da latência estava dentro dos padrões de normalidade;

- Aumentada, quando a latência estava aumentada em relação ao padrão normal;

Assim, as Ondas I, III e V apresentaram latências normais em 37 orelhas (84\%) e aumentadas em 7 (16\%), como podemos visualizar no Gráfico 10. Todos os intervalos interpicos apresentaram valores normais.

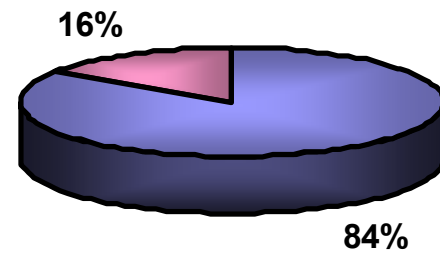

口Normais

口 Aumentadas

GRÁFICO 10 - Resultados da análise das latências absolutas das ondas I, III e V do PEATE no GHL.

Os resultados do PEATE também foram classificados de modo geral em normal, condutivo ou alterado, assim como no GH.

No GHL não houve nenhum exame considerado como alterado; apenas 4 pacientes apresentaram alteração condutiva $(18 \%)$ e todos os demais $(82 \%)$ tiveram resultados normais. Podemos visualizar essa distribuição no Gráfico 11. 


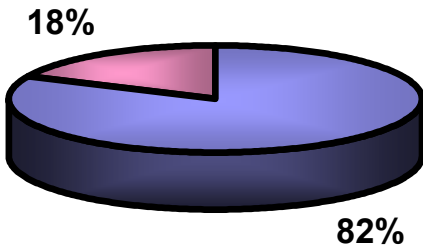

\section{DNormais \\ GCondutivos}

GRÁFICO 11 - Distribuição dos resultados do PEATE no GRUPO HL.

Para comparar as porcentagens de resultados normais e alterados entre os grupos HL e C foi realizado o teste do Qui-quadrado de associação.

Observamos uma semelhança entre os resultados de todas as variáveis, uma vez que não foram encontradas diferenças estatisticamente significantes. Os resultados desse teste estão nas tabelas 18,19 e 20 .

TABELA 18 - Comparação da análise da latência absoluta da onda I entre GHL e GC por meio do teste do Qui-quadrado.

\begin{tabular}{llc}
\hline & GHL & GC \\
\hline Normal & $\mathbf{3 7}$ & 44 \\
\hline Aumentada & $\mathbf{7}$ & 0 \\
\hline $\mathbf{X}^{\mathbf{2}=\mathbf{7 . 6 0}}$ & $\mathbf{g . l .}=\mathbf{1}$ & $\mathrm{p}=0.0180$ \\
\hline
\end{tabular}

TABELA 19 - Comparação da análise da latência absoluta da onda III entre GHL e GC por meio do teste do Qui-quadrado.

\begin{tabular}{llc}
\hline & GHL & GC \\
\hline Normal & $\mathbf{3 7}$ & 44 \\
\hline Aumentada & $\mathbf{7}$ & 0 \\
\hline $\mathbf{X}^{\mathbf{2}}=\mathbf{7 . 6 0}$ & g.l.= & $\mathrm{p}=0.0180$ \\
\hline
\end{tabular}


TABELA 20 - Comparação da análise da latência absoluta da onda V entre GHL e GC por meio do teste do Qui-quadrado.

\begin{tabular}{llc}
\hline & GHL & GC \\
\hline Normal & $\mathbf{3 7}$ & 44 \\
\hline Aumentada & $\mathbf{7}$ & 0 \\
\hline $\mathbf{X}^{\mathbf{2}=\mathbf{7 . 6 0}}$ & g.l. $=\mathbf{1}$ & $\mathrm{p}=0.0180$ \\
\hline
\end{tabular}

Em virtude dos valores das latências interpicos do GHL estarem dentro dos limites da normalidade em ambas as orelhas, não houve necessidade de estudo estatístico.

TABELA 21- Apresentação dos p-value obtidos no estudo estatístico, comparando os valores de latências dos três grupos estudados, por meio do teste ANOVA.

\begin{tabular}{lc}
\hline Variáveis & \multicolumn{1}{l}{} \\
\hline I OD & $0,00016^{*}$ \\
\hline III OD & $0,00003^{*}$ \\
\hline V OD & $0,00000^{*}$ \\
\hline I-V OD & $0,00243^{*}$ \\
\hline III-V OD & $0,00017^{*}$ \\
\hline I-III OD & 0,24221 \\
\hline I OE & $0,00009^{*}$ \\
\hline III OE & $0,00002^{*}$ \\
\hline V OE & $0,00000^{*}$ \\
\hline I-V OE & $0,00313^{*}$ \\
\hline III-V OE & $0,00021^{*}$ \\
\hline I-III OE & 0,10881 \\
\hline Dif. i.a.V & $0,00994^{*}$ \\
\hline
\end{tabular}

Após a aplicação da ANOVA, as variáveis com diferença significativa foram submetidas ao Teste de Tukey para comparações múltiplas entre os três grupos. 
TABELA 22- Médias e desvios-padrão (DP) dos valores obtidos no três grupos para cada variável estudada e resultado do Teste de Tukey, considerando $\mathrm{p}=0,05$.

Grupos marcados com a mesma letra não possuem diferença estatisticamente significante entre si.

\begin{tabular}{|c|c|c|c|c|c|c|}
\hline \multirow[t]{2}{*}{ Variáveis } & \multicolumn{2}{|l|}{ GH } & \multicolumn{2}{|l|}{ GHL } & \multicolumn{2}{|l|}{ GC } \\
\hline & Média & DP & Média & DP & Média & DP \\
\hline$\overline{\mathrm{I} O D}$ & $2,21^{\mathrm{a}}$ & 0,254 & $1,99^{b}$ & 0,221 & $1,92^{b}$ & 0,070 \\
\hline III OD & $4,35^{a}$ & 0,304 & $4,04^{b}$ & 0,230 & $3,97^{b}$ & 0,103 \\
\hline V OD & $6,47^{a}$ & 0,424 & $5,95^{b}$ & 0,221 & $5,90^{b}$ & 0,102 \\
\hline $\mathrm{I}-\mathrm{V}$ OD & $4,20^{a}$ & 0,454 & $3,94^{b}$ & 0,096 & $3,97^{b}$ & 0,110 \\
\hline III-V OD & $2,24^{\mathrm{a}}$ & 0,443 & $1,91^{\mathrm{b}}$ & 0,088 & $1,92^{b}$ & 0,055 \\
\hline I-III OD & $2,14^{\mathrm{a}}$ & 0,317 & $2,03^{b}$ & 0,078 & $2,04^{b}$ & 0,100 \\
\hline I OE & $2,19^{a}$ & 0,275 & $2,01^{b}$ & 0,225 & $1,91^{b}$ & 0,079 \\
\hline III OE & $4,52^{a}$ & 0,510 & $4,04^{b}$ & 0,238 & $3,94^{b}$ & 0,101 \\
\hline $\mathrm{V} \mathrm{OE}$ & $6,51^{a}$ & 0,525 & $5,94^{b}$ & 0,253 & $5,90^{b}$ & 0,109 \\
\hline I-V OE & $4,24^{\mathrm{a}}$ & 0,505 & $3,92^{b}$ & 0,093 & $3,97^{b}$ & 0,115 \\
\hline III-V OE & $2,07^{a}$ & 0,141 & $1,90^{b}$ & 0,092 & $1,95^{b}$ & 0,066 \\
\hline I-III OE & $2,33^{a}$ & 0,604 & $2,01^{b}$ & 0,095 & $2,01^{b}$ & 0,100 \\
\hline V i.a. & $0,13^{a}$ & 0,149 & $0,06^{\mathrm{a}}$ & 0,064 & $0,03^{b}$ & 0,047 \\
\hline
\end{tabular}

Para todas as variáveis, o GH mostrou-se diferente dos outros dois grupos, ou seja, houve diferença estatisticamente significante quando comparamos o $\mathrm{GH}$ com o GHL e com o GC e não houve diferença quando o GHL foi comparado com o GC.

A única exceção foi a diferença interaural da onda $\mathrm{V}$, pois o valor obtido no $\mathrm{GC}$ foi significativamente menor que os obtidos nos GH e GHL que, por sua vez, não diferiram estatisticamente entre si.

Foi realizada comparação dos grupos experimentais, ou seja, os pacientes com HPE clássica e like, com os indivíduos normais. Para isso, foi aplicado o Teste t de Student para Dados Pareados, comparando as médias do GH + GHL com as médias do 
GC. Observamos diferença estatisticamente significante para as latências absolutas e para a diferença interaural da onda $\mathrm{V}$, mas não para as latências interpicos.

TABELA 23- Distribuição das médias e desvios-padrão (DP) do GH+GHL e do GC e significância (p) da diferença das latências do PEATE segundo o teste t de Student.

\begin{tabular}{lccccc}
\hline Variáveis & \multicolumn{1}{l}{ GH+GHL } & \multicolumn{2}{l}{ GC } & P \\
\cline { 2 - 5 } & Média & DP & Média & DP & \\
\hline I OD & 2,07 & 0,254 & 1,92 & 0,070 & $0,0094^{*}$ \\
\hline -III OD & 4,15 & 0,298 & 3,97 & 0,103 & $0,0073^{*}$ \\
\hline V OD & 6,12 & 0,387 & 5,90 & 0,102 & $0,0097^{*}$ \\
\hline I-V OD & 4,03 & 0,294 & 3,97 & 0,110 & 0,3983 \\
\hline III-V OD & 2,02 & 0,303 & 1,92 & 0,055 & 0,1449 \\
\hline I-III OD & 2,07 & 0,205 & 2,04 & 0,100 & 0,4459 \\
\hline I OE & 2,08 & 0,256 & 1,91 & 0,079 & $0,0059^{*}$ \\
\hline III OE & 4,22 & 0,427 & 3,94 & 0,101 & $0,0046^{*}$ \\
\hline V OE & 6,11 & 0,442 & 5,90 & 0,109 & $0,0309^{*}$ \\
\hline I-V OE & 4,02 & 0,319 & 3,97 & 0,115 & 0,5057 \\
\hline III-V OE & 1,95 & 0,131 & 1,95 & 0,066 & 0,9926 \\
\hline I-III OE & 2,13 & 0,399 & 2,01 & 0,100 & 0,1775 \\
\hline V i.a. & 0,08 & 0,100 & 0,03 & 0,047 & $0,0197^{*}$ \\
\hline
\end{tabular}

Em relação ao traçado do PEATE, encontramos diferenças significativas nos resultados dos exames dos grupos experimentais (GH e GHL), variando de normais ou levemente alterados (no caso das perdas auditivas condutivas) até aqueles com alterações severas, ausência de ondas, pobre morfologia e pouca reprodutibilidade. $\mathrm{Na}$ figura 8 podemos observar três exemplos de traçados do PEATE. 

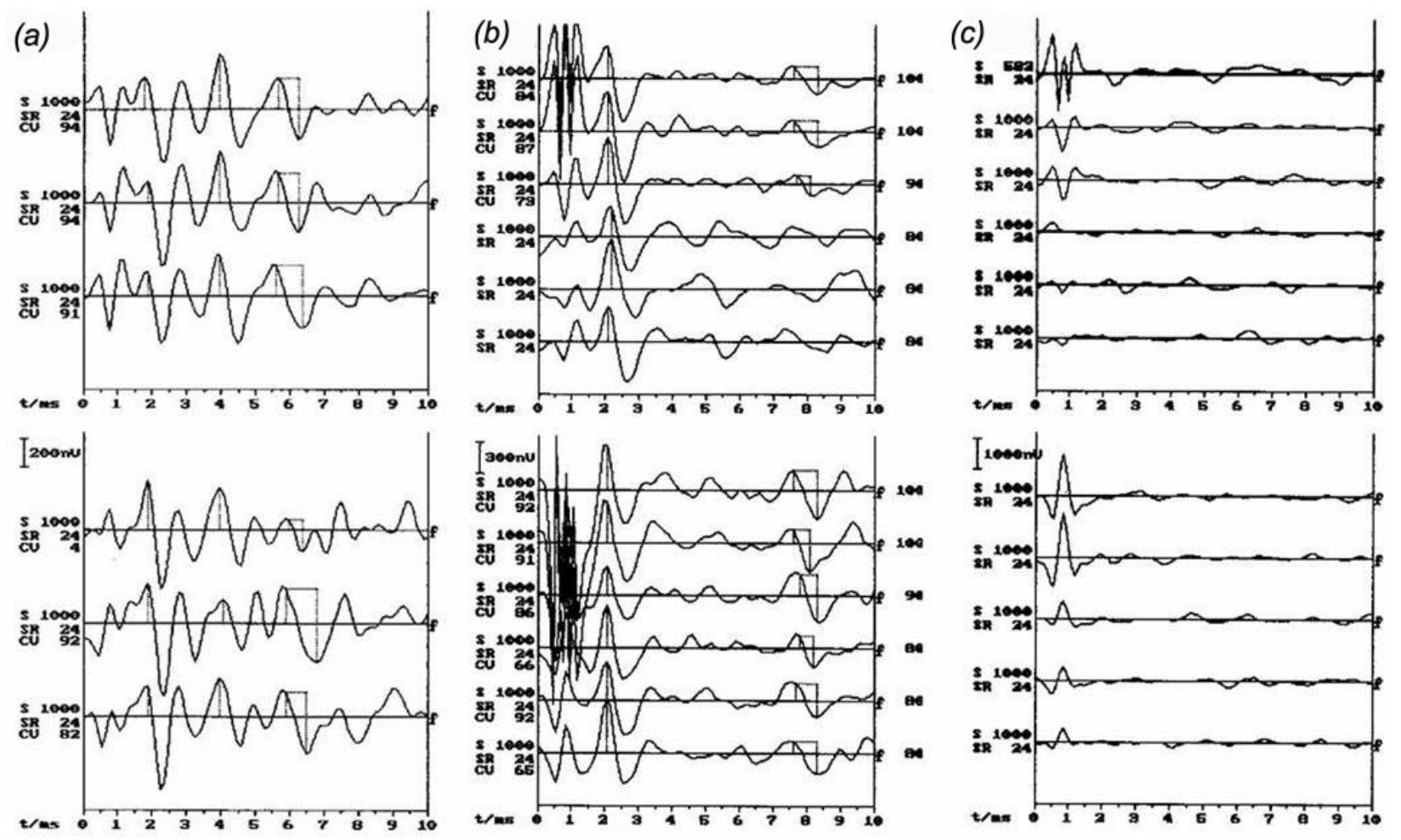

Figura 8 - Exemplos de traçados do PEATE obtidos em pacientes dos grupos H e HL mostrando: (a) exame com latências, morfologia e reprodutibilidade de ondas normais; (b) exame alterado, com atraso de latências e ausência de ondas e (c) exame severamente alterado, apresentando ondas de pobre morfologia e reprodutibilidade. 


\section{DISCUSSÃO}

Uma análise crítica dos resultados obtidos no presente estudo, bem como a comparação com resultados compilados e descritos por outros pesquisadores da área de potenciais evocados auditivos e estudiosos da holoprosencefalia será realizada neste capítulo. Essas duas áreas serão descritas na maioria das vezes de forma independente, uma vez que não foram encontrados trabalhos cujo objetivo fosse semelhante ao dessa pesquisa.

\subsection{Considerações sobre a calibração biológica}

Quanto às latências absolutas, de modo geral, os valores estabelecidos para o equipamento utilizado neste estudo foram maiores quando comparados aos obtidos por Jewett e Williston (1971) e semelhantes àqueles compilados e descritos por Sequeira e Fukuda (1988), Costa Filho e Celani (1993) Hall e Mueller (1997) e Hood (1998). Os valores máximos propostos pela maior parte destes autores para cada onda estiveram mais próximos aos valores mínimos encontrados neste estudo.

Chiappa et al (1979) propôs $1,8 \mathrm{~ms}$ para a onda I, o que está em acordo com este estudo; entretanto os valores das ondas III e V propostos foram maiores; de 4,2 ms para a onda III e de 6,2 ms para a onda V.

Os resultados descritos por Jewett e Williston (1971) foram os que mais destoaram daqueles obtidos no presente estudo, por serem muito precoces.

Foi encontrada diferença clínica de latências entre os gêneros masculino e feminino, sendo as latências absolutas 0,1 ou 0,2 ms mais precoces no gênero feminino, 
embora não seja estatisticamente significante. Achados semelhantes foram descritos por Chu (1985), Rodriguez et al (1989), Macedo et al (1990) e Chiappa et al (1979).

\subsection{Caracterização dos grupos}

Os pacientes do GH apresentaram faixa etária inferior quando comparados aos pacientes do GHL. Esta diferença pode ser atribuída ao fato de os pacientes do GH apresentarem quadros de maior comprometimento e, portanto, menor expectativa de vida, conforme estudo apresentado por Barr e Cohen (1999). Entretanto, embora a média etária tenha sido baixa, aproximadamente 3 anos, encontramos um paciente com 14 anos de idade. Isso pode ser explicado pela variação no tempo de sobrevivência já descrita na literatura por Stashinko et al (2004).

No GHL, a faixa etária foi mais abrangente, variando desde indivíduos muito jovens até indivíduos adultos, uma vez que o diagnóstico de HPE-like não implica em diminuição da expectativa de vida. Esse fenótipo foi recentemente descrito e, portanto, poucos estudos contemplam sua evolução, mas pela afirmação de que anormalidades do sistema nervoso central não fazem parte do quadro (Santiago et al 2006) fica implícita a ausência de manifestações que justifiquem uma sobrevida reduzida.

Os indivíduos do GC foram pareados por idade aos indivíduos dos demais grupos, portanto a discussão acerca da faixa etária deste grupo não se faz necessária.

Em todos os grupos estudados, o gênero feminino foi predominante, especialmente no GHL, no qual representou 77\% da amostra. No GC, o desvio da razão de gênero pode ser explicado pelo fato dessa amostra ser pareada em gênero aos grupos H e HL, aos quais seria inerente essa desproporção. 
Não foram encontrados na literatura estudos que apontem a maior ocorrência de HPE no gênero feminino e esse achado isolado não deve ser generalizado, especialmente devido à pequena casuística estudada.

A maioria dos pacientes do GH, único grupo ao qual a variável "tipo de HPE” é pertinente, apresentou o tipo alobar de HPE. Não existem relatos na literatura de que algum dos 3 tipos de HPE apresente maior ocorrência, de modo que este fato pode ser considerado como inerente apenas à amostra estudada e não deve ser generalizado, tendo em vista a pequeno número de pacientes.

Muito embora a identificação de mutação em algum gene determinante de HPE seja bastante esclarecedora, especialmente com relação à etiologia do quadro, tal tarefa não pode ser considerada simples, devido à existência de vários genes candidatos e a complexidade dos procedimentos. Assim, não foram testados neste estudo todos os genes candidatos, não sendo possível afirmar que os pacientes considerados "sem mutações" não apresentam mutação nenhuma, mas sim que eles não as apresentam nos 4 genes estudados. Entretanto, em certos casos, podem ser sugeridas algumas correlações positivas: os três pacientes com mutação no gene SIX3 apresentaram o tipo alobar de HPE e os resultados do PEATE revelaram alteração neural; possivelmente o gene SIX3 é responsável indireto, pois é descrita na literatura sua expressão durante a formação do tronco encefálico (Kikuta et al 2003, Tallafuss et al 2003).

Mutações no gene SHH foram encontradas em 2 indivíduos do GH com o tipo semilobar de HPE, sendo que um deles apresentou resultado do PEATE normal e o outro, alterado; e em outros 4 indivíduos do GHL, com o tipo like e sem alterações neurais de PEATE. Essas mutações foram responsáveis por quadros menos graves, cujo sistema nervoso central está menos comprometido e, da mesma forma, os achados do PEATE. 
Apenas 2 indivíduos apresentaram mutações no gene GLI2, um do GH, com HPE do tipo lobar e um do GHL, com HPE-like. Nenhum desses pacientes apresentou alteração neural do PEATE, e a hipótese sugerida seria a mesma proposta para o gene SHH, ou seja, a menor severidade dos quadros. Um paciente com HPE-like apresentou mutação no gene PTCH e não foram encontradas alterações de PEATE. Não foi possível estabelecer maiores correlações entre o tipo de mutação e o resultado do PEATE pelo pequeno número de pacientes estudados.

\subsection{Procedimentos prévios}

\subsubsection{Anamnese}

No grupo GH, embora alguns pais tenham relatado queixas auditivas como hipoacusia e otites, a maioria não o fez, de modo que, apesar de a maioria dos pacientes apresentarem alterações auditivas, a maior parte dos pais negou queixas. Isso pode ser explicado de algumas formas: em virtude do comprometimento global de desenvolvimento dos pacientes, os pais podem não ter dispensado atenção especial à questão auditiva, ou pela própria limitação imposta pelo baixo nível sócio-econômicocultural da maioria das famílias. Além disso, a otite média serosa pode não ter sido percebida pelos pais, uma vez que se trata de quadro assintomático. Maiores aferições podem ser inapropriadas, pois nesse estudo não foi estimada a acuidade auditiva dos pacientes.

Em contrapartida, no grupo GHL, a grande maioria dos pais não apresentou queixa auditiva, concordando com a baixa ocorrência de alterações auditivas nessa 
população. As poucas queixas foram compatíveis com o quadro de alteração de orelha média apresentado.

\subsubsection{Audiometria}

Este procedimento foi realizado apenas no GHL e GC, sendo critério de inclusão nesse último grupo, de modo que tais resultados não serão discutidos. No GHL, a maioria dos resultados foi normal, e os alterados consistiram de perda auditiva condutiva leve, compatível com a timpanometria, que revelou alteração de orelha média. A ocorrência de otite média na população com fissura labiopalatina é bem documentada na literatura (Sheahan et al 2002, Sheahan e Blayney 2003, Sheahan et al 2003, Tuncbilek et al 2003, Ramana et al 2005, dentre outros), e estas alterações parecem estar diretamente ligadas à presença da fissura de palato, independentemente do quadro de HPE-like.

\subsubsection{Imitanciometria}

Os pacientes do GH apresentaram, em sua maioria, alterações imitanciométricas, provavelmente decorrentes de otite média.

No GHL, também foram detectadas alterações do mesmo tipo, porém em poucos pacientes.

Como já citado no item Audiometria, essas alterações podem ser atribuídas aos problemas de orelha média nos pacientes com fissura de palato. Nesses pacientes, a inserção do músculo tensor do véu palatino é anormal, e esse desvio anatômico pode persistir mesmo após correção cirúrgica da fenda. Esse músculo atua na abertura da tuba 
auditiva, estrutura responsável pela aeração da orelha média, e estando comprometido, não pode desempenhar essa função adequadamente (Pegoraro-Krook et al 2004). Assim, pela falta de aeração na orelha média ocorrem mudanças fisiológicas e estruturais na mucosa que favorecem a ocorrência das otites médias, muitas vezes reincidivantes (Sheahan et al 2004, Chu e McPherson 2005).

A imitanciometria, por ser um exame sensível às alterações de orelha média, detectou tais anormalidades na população estudada. Não existem estudos na literatura relatando problemas de audição do tipo condutivo em pacientes com HPE.

\subsection{PEATE}

\subsubsection{Grupo Controle (GC)}

Comparando os resultados obtidos nos indivíduos deste grupo com os valores estabelecidos para a normalidade, observamos uma semelhança, de modo que todos os resultados obtidos no GC foram considerados normais. Esse achado reflete a premissa de que, na ausência de patologias auditivas, malformações de sistema nervoso central, fissura palatina e queixas auditivas, os achados do PEATE provavelmente estarão adequados (Hall e Mueller 1997, Hood 1998, Chiappa et al 1979).

\subsubsection{Grupo com Holoprosencefalia Clássica (GH)}

Neste grupo, apesar dos vários tipos de resultados encontrados, o predominante envolve alterações do tipo neural. Esse achado corrobora com os três estudos encontrados na literatura descrevendo achados de PEATE na HPE. 
Castro Júnior et al, 2000 relataram um caso de HPE alobar no qual foi realizada avaliação audiológica objetiva. Os PEATE revelaram anormalidades, com presença das ondas I e III, sendo a latência interpicos I-III aumentada e ausência de onda V. Esses resultados demonstram semelhança com os achados do PEATE de alguns pacientes descritos no presente estudo, especialmente os casos de HPE alobar. Provavelmente esses casos, por envolverem malformações cerebrais mais amplas e severas, impõem a estes pacientes maiores problemas relacionados às vias auditivas centrais, especialmente no nível do tronco encefálico, estrutura responsável pela geração da onda V do PEATE $(\operatorname{Hood} 1998)$.

Em nosso estudo, não houve nenhum paciente com ausência total de ondas do PEATE, apenas ausência da onda V e atraso das demais. Shoda et al (1990) relataram um caso de HPE alobar com ausência total de PEATE. Como o caso descrito apresentava outras anormalidades além da HPE, como a hidrocefalia, acreditamos que o grau de severidade das malformações cerebrais foi o diferencial entre os resultados do PEATE.

Um outro estudo, realizado por Coupland e Sarnat (1990) também descreveu anormalidades de PEATE em pacientes com HPE, contudo estas anormalidades não foram caracterizadas, o que limita uma comparação mais detalhada.

Encontramos ainda na literatura trabalhos que descrevem os PEATE em alguns tipos de malformações cerebrais, não especificamente a HPE. Em casos de hidrocefalia, têm sido documentadas alterações de PEATE, como no estudo realizado por Kraus et al (1984) em pacientes com hidrocefalia, dos quais $80 \%$ tinham algum tipo de anormalidade. As respostas indicativas de disfunção de tronco encefálico consistiram de latência interpicos I-V aumentada (38\%), amplitude V reduzida (33\%) e anormalidades na configuração das ondas III (27\%) e V (53\%). Em adição, 70\% dos pacientes tiveram 
limiares eletrofisiológicos aumentados. Os autores sugeriram que a disfunção de tronco encefálico dificulta a mensuração da sensitividade auditiva nos pacientes com hidrocefalia.

Os outros achados de PEATE neste grupo se enquadram no tipo de anormalidade causada por patologias condutivas, ou seja, o aumento de latências absolutas.

\subsubsection{Grupo com Holoprosencefalia-like (GHL)}

Neste grupo encontramos basicamente resultados normais de PEATE, sendo as únicas anormalidades atribuídas a patologias de orelha média. Considerando que pacientes com esse diagnóstico não apresentam malformações de sistema nervoso central, tais alterações não seriam esperadas. Como já explicado no item Imitanciometria, patologias de orelha média são comumente encontradas na população de pacientes com fissura de palato, malformação presente em parte da amostra desse grupo.

Alterações condutivas causam um tipo específico de alteração de PEATE, que consiste no aumento apenas das latências absolutas (Hall e Mueller 1997, Hood 1998, Antoneli et al 2006).

\subsubsection{Considerações sobre o PEATE nos grupos experimentais}

Malformações cerebrais não caracterizam o quadro de HPE-like e consistem em condição sine qua non para o diagnóstico de HPE clássica. Assim sendo, verificamos que o padrão de PEATE está intimamente relacionado à integridade do sistema nervoso 
central, especialmente no que diz respeito ao tronco encefálico, sendo produto desta (a)normalidade e refletindo-a. A importância do sistema auditivo íntegro em suas porções periférica e central na geração dos PEATE é documentada na literatura (Hall e Mueller 1997, Hood 1998, Chiappa et al 1979).

Patologias condutivas foram encontradas nos dois grupos, causando provavelmente o mesmo tipo de alteração que, no $\mathrm{GH}$, somadas às demais anormalidades, tomaram outra forma. Esse fato justifica a distinção "condutivo $\mathrm{x}$ neural" utilizada neste estudo, mediante a qual, em um mesmo exame, pode ser identificado um "componente condutivo", justificado pelos achados anormais da timpanometria e um "componente neural", caracterizado por outros desvios da normalidade que não apenas o aumento de latências absolutas.

Por outro lado, alterações de condução neural foram apenas encontradas nos pacientes do $\mathrm{GH}$, especialmente naqueles com maiores comprometimentos (HPE alobar). Esses são os únicos achados passíveis de comparação, mediante os três estudos já citados no item 6.4.2. No caso dos achados de HPE-like, não existem estudos relacionados, pelo fato de este fenótipo ter sido descrito apenas recentemente e suas manifestações ainda serem pouco exploradas. 


\section{CONCLUSÃO}

Um conceito básico em neurociência é relacionar determinadas funções a estruturas neurais específicas e/ou genes específicos que atuam no desenvolvimento do sistema nervoso central e vias correlatas.

Assim, foi possível concluir que pacientes com holoprosencefalia clássica apresentam alterações de PEATE compatíveis com a gravidade das malformações cerebrais.

De todos os parâmetros analisados, a onda $\mathrm{V}$ foi marcadamente mais afetada, fato que pode ser justificado primariamente por alterações intrínsecas de tronco encefálico, especialmente a hipoplasia, uma vez que esta onda do PEATE é gerada pela atividade do lemnisco lateral e do colículo inferior. Apesar disso, não se pode descartar um efeito secundário ou associado do alargamento ventricular e da hidrocefalia, presentes em alguns pacientes com HPE clássica.

Pacientes com HPE-like não apresentaram alterações na condução neural de estímulos auditivos até o nível do tronco encefálico, que pudessem ser demonstradas pelo PEATE. Embora tenham sido detectadas apenas alterações periféricas, decorrentes de patologias de orelha média, a possibilidade de alterações em outros níveis do sistema auditivo torna muito importante a investigação das vias mais altas, envolvendo estruturas talâmicas e corticais. Potenciais auditivos de média e longa latência podem ser ferramentas úteis na complementação diagnóstica desse quadro ainda tão pouco explorado.

Com relação às mutações, pouco se pode inferir, devido à pequena casuística e o pequeno número de mutações encontradas. Apesar disso, uma relação com gene específico ou o efeito secundário de sua mutação sobre a formação do sistema nervoso 
pode ser sugerida, uma vez que todos os pacientes com mutação no gene SIX3 apresentaram resultados semelhantemente alterados de PEATE.

Os PEATE forneceram informações valiosas a respeito das vias auditivas subcorticais, sendo especialmente úteis nos casos de HPE clássica, aos quais são inerentes malformações nesse nível do sistema auditivo. 


\section{REFERÊNCIAS BIBLIOGRÁFICAS}

Aguilella C, Dubourg C, Attia-Sobol J, Vigneron J, Blayau M, Pasquier L, et al. Molecular screening of the TGIF gene in holoprosencephaly: identification of two novel mutations. Hum Gen 2003; 112: 131-4.

Ahlgren SC, Bronner-Fraser M. Inhibition of sonic hedgehog signaling in vivo results in craniofacial neural crest cell death. Curr Biol 1999; 9: 1304-14.

Antoneli MZ, Zanchetta S, Zorzetto NL. Potenciais Evocados Auditivos de Tronco Encefálico em crianças com fissura palatina e alteração de orelha média. In: Anais do $21^{\circ}$ Encontro Internacional de Audiologia; 2006, 20-23 abril; Bauru- SP, Brasil. CDRom.

Aubry JP, Aubry MC, Briard ML, Henrion R. Prenatal ultrasound measurement of the interorbital distance. Method of recognizing lesser degrees of holoprosencephaly. $J$ Genet Hum 1981; 29: 395-407.

Barkovich AJ, Quint DJ. Middle interhemisferic fusion: an unusual variant of holoprosencephaly. Am J Neuroradiol 1993; 14: 431-40.

Barr Jr M, Cohen Jr MM. Holoprosencephaly survival and performance. Am J Med Genet 1999; 89: 116-20.

Barr Jr M, Hanson JW, Currey K, Sharp S, Toriello H, Schmickel RD, et al. Holoprosencephaly in infants of diabetic mothers. J Pediatr 1983; 102: 565-8. 
Belloni E, Muenke M, Roessler E, Traverso G, Siegel-Bartelt J, Frumkin A, et al. Identification of sonic hedgehog as a candidate gene responsible for holoprosencephaly. Nat Gen 1996; 14: 353-6.

Berry SA, Pierpont ME, Gorlin RJ. Single central incisor in familial holoprosencephaly. J Pediatr 1984; 104: 877-80.

Binns W, James LF, Shupe JL, Everett G. A congenital cyclopian-type malformation in lambs induced by maternal ingestion of a range plant, veratrum californicum. J Am Vet Med Assoc 1963; 147: 839-42.

Blader P, Strahle U. Casting an eye over cyclopia. Nature 1998; 395:112-3.

Bonnemann C, Meinecke P. Holoprosencephaly as a possible embryonic alcohol effect: another observation. Am J Med Genet 1990; 37: 431-2.

Brown LY, Odent S, David V, Blayau M, Dubourg C, Apacik C, et al. Holoprosencephaly due to mutations in ZIC2: alanine tract expansion mutations may be caused by parental somatic recombination. Hum Mol Genet 2001; 10: 791-6.

Brown SA, Warburton D, Brown LY, Yu CY, Roeder ER, Stengel-Rutskowski S, et al. Holoprosencephaly due to mutations in ZIC2, a homologue of Drosophila odd-paired. Nat Gen 1998; 20: 180-3.

Bullen PJ, Rankin JM, Robson SC. Investigation of the epidemiology and prenatal diagnosis of holoprosencephaly in the north of England. Am J Obstet Gynecol 2001; 184: $1256-62$. 
Byrne PJ, Silver MM, Gilbert JM, Cadera W, Tanswell AK. Cyclopia and congenital cytomegalovirus infection. Am J Med Gen 1987; 28: 61-5.

Cameron FJ, Khadilkar VV, Stanhope R. Pituitary dysfunction, morbidity and mortality with congenital midline malformation of the cerebrum. Eur J Pediatr 1999; 158: 97102.

Carlson BM. Human embriology \& developmental biology. St Louis: Mosby; 1999.

Castro Júnior NP, Granato L, Figueiredo MS, Rios OAB. Holoprosencefalia com probóscide: caso clínico. Rev Bras Otorrinolaringol 2000; 66 (3 pt1): 273-6.

Cazals Y, Bories V, Aran JM. Some uncertainties in scalp recordings of brainstem auditory potentials in monkey and man. Rev Laryngol Otol Rhinol 1978; 99: 663-79.

Chen F, Chern SR, Du SH, Wang W. Molecular diagnosis of a novel heteroziguous 268C-->T (R90C) mutation in TGIF gene in a fetus with holoprosencephaly and premaxillary agenesis. Prenat Diagn 2002; 22: 5-7.

Chiappa KH, Gladstone KJ, Young RR. Brain stem auditory evoked responses: studies of waveform variations in 50 normal human subjects. Arch Neurol 1979; 36: 81-7.

Chu KM, McPherson B. Audiological status of Chinese patients with cleft lip/palate. Cleft Palate Craniofac J 2005; 42(3): 280-5.

Chu NS. Age-related latency changes in the brain-stem auditory evoked potentials. Electroencephalogr Clin Neurophysiol 1985; 62: 431-6. 
Cohen Jr MM. Perspectives on holoprosencephaly: part I. Epidemiology, genetics and syndromology. Teratology 1989a; 40: 211-35.

Cohen Jr MM. Perspectives on holoprosencephaly: part III. Spectra, distinctions, continuities and discontinuities. Am J Med Genet 1989b; 34: 271-88.

Cohen Jr MM. Problems in the definitions of holoprosencephaly. Am J Med Genet 2001; 103: 183-7.

Cohen M, Fraser FC, Gorlin RJ. Craniofacial disorders. In: Emery AEH, Rimoin DL, editors. Principles and practice of medical genetics, vol 1. Edinburg: Churchill Livingstone; p. 749-96.

Cohen Jr MM, Shiota K. Teratogenesis of holoprosencephaly. Am J Med Genet 2002; 109: 1-15.

Cohen Jr MM, Sulik KK. Perspectives on holoprosencephaly, II. Central nervous system, craniofacial anatomy, syndrome commentary, diagnostic approach, and experimental studies. J Craniofac Genet Dev Biol 1992; 12:196 -244.

Coll Masfarre S, Majos Torro C, Aguilera Grijalvo C, Pons Irazazabal LC. Middle interhemisferic fusion. Eur Radiol 1998; 8: 631-3.

Cooper MK, Porter JA. Young KE, Beachy PA. Teratogen-mediated inhibition of target tissue resonse to Shh signaling. Science 1998; 280: 1603-7.

Costa Filho OA, Celani AC. Audiometria de respostas elétricas do tronco cerebral. Folha Méd 1993; 107: 43-8. 
Coulter CL, Leech RW, Schaefer GB, Scheithauer BW, Brumback RA. Midline cerebral dysgenesis, dysfunction of the hypothalamic-pituitary axis and fetal alcohol effects. Arch Neurol 1993; 50: 771-5.

Coupland SG, Sarnat HB. Visual and auditory evoked potential correlates of cerebral malformations. Brain Dev 1990; 12: 466-72.

Croen LA, Shaw GM, Lammer EJ. Holoprosencephaly: epidemiologic and clinical characteristics of a California population. Am J Med Genet 1996; 64: 456-72.

de la Cruz JM, Bamford RN, Burdine RD, Roessler E, Barkovich AJ, Donnai D, et al. A loss-of-function mutation in the CFC domain of TDGF1 is associated with human forebrain defects. Hum Genet 2002; 110: 422-8.

DeMyer W, Zeman W. Alobar holoprosencephaly (arhinencephaly) with median cleft lip and palate: clinical, eletroencephalographic and nosologic considerations. Confin Neurol 1963; 23: 1-36.

DeMyer W, Zeman W, Palmer CG. The face predicts the brain: diagnostic significance of median facial anomalies for holoprosencephaly (arhinencephaly). Pediatrics 1964; 34: $256-63$

Dubourg C, Lazaro L, Pasquier L, Bendavid C, Blayau M, Le Duff F, et al. Molecular screening of SHH, ZIC2, SIX3 and TGIF genes in patients with features of holoprosencephaly spectrum: mutation review and genotype-phenotype correlations. Hum Mut 2004; 24: 43-51. 
Elias DL, Kawamoto HR, Wilson LF. Holoprosencephaly and midline facial anomalies: redefining classification and management. J Plast Reconstr Surg 1992; 35: 901-8.

Fryns JP, Van den Berghe H. Single central maxillary incisor and holoprosencephaly. Am J Med Gen 1988; 30: 943-4.

Golden JA. Holoprosencephaly: a defect in brain patterning. J Neuropathol Exp Neurol 1998; 57: 991-9.

Gripp KW, Wotton D, Edwards MC, Roessler E, Ades L, Meinecke P, et al. Mutations in TGIF cause holoprosencephaly and link NODAL signaling to human neural axis determination. Nat Genet 2000; 25: 205-8.

Hall JW. Handbook of auditory evoked responses. Needham Heights: Allyn and Bacon; 1992.

Hall JW, Mueller HG. Audiologists 'desk reference: diagnostic audiology principles, procedures and practices. San Diego: Singular; 1997.

Hasegawa Y, Hasegawa T, Yokoyama T, Kotoh S, Tsuchiya Y. Holoprosencephaly associated with diabetes insipidus and syndrome of inappropriate secretion of antidiuretic hormone. J Pediatr 1990; 117: 756-8.

Hattori H, Okuno T, Momoi T, Kataoka K, Mikawa H, Shiota K. Single central maxillary incisor and holoprosencephaly. Am J Med Genet 1987; 28: 483-7. 
Helms JA, Kim CH, Hu D, Minkoff R, Thaller C, Eichele G. Sonic hedgehog participates in craniofacial morphogenesis and is down-regulated by teratogenic doses of retinoic acid. Dev Biol 1997; 187: 25-35.

Hill LM, Breckle R, Bonebrake CR. Ultrasonic findings with holoprosencephaly. $J$ Reprod Med 1982; 27: 172-5.

Hood LJ. Clinical applications of the auditory brainstem response. San Diego: Singular; 1998.

Jewett DL, Williston JS. Auditory evoked far fields averaged from the scalp pf humans. Brain 1971; 4: 681-96.

Jing H, Flax J, Roesler CP, Choudhury N, Benasich AA. Auditory event-related responses in children with semi-lobar holoprosencephaly. Brain Develop 2006; 28: $207-$ 14.

Incardona JP, Gaffield W, Kapur RP, Roelink H. The teratogenic veratrum alkaloid cyclopamine inhibits sonic hedgehog signal transduction. Development 1998; 125: 3553-62.

Jaramillo C, Brandt SK, Jorgenson RJ. Autosomal dominant inheritance of the DeMyer sequence. J Craniofac Genet Dev Biol 1988; 8:199-204.

Junqueira CAO, Frizzo ACF. Potenciais evocados auditivos de curta, média e longa latência. In: Aquino, AMCMA. Processamento auditivo: eletrofisiologia $e$ psicoacústica. São Paulo: Lovise; 2002. p. 63-86. 
Kalter H. Cyclops produced in a very early retinoic acid experiment. Teratology 1992; 46: 207-8.

Keeler RF, Binns W. Teratogenic compounds of veratrum californicum (durand) V. Comparison of cyclopian effects of steroidal alkaloids from the plant and structurally related compounds from others sources. Teratology 1968; 1: 1-10.

Kelley RL, Roessler E, Hennekam RC, Feldman GL, Kosaki K, Jones M, et al. Holoprosencephaly in RSH/ Smith-Lemli-Opitz syndrome: does abnormal cholesterol metabolism affect the function of sonic hedgehog? Am J Med Genet 1996; 66: 478-84.

Kikuta H, Kanai M, Ito Y, Yamasu K. gbx2 Homeobox gene is required for the maintenance of the isthmic region in the zebrafish embryonic brain. Dev Dyn 2003; 228: 433-50.

Kotzot D, Weigl J, Huk W, Rott HD. Hydantoin syndrome with holoprosencephaly: a possible rare teratogenic effect. Teratology 1993; 48: 15-9.

Koyama N, Komori S, Bessho T, Koyama K, Hiraumi Y, Maeda Y. Holoprosencephaly in a fetus with maternal medication of sulfasalazine in early gestation. A case report. Clin Exp Obstet Gynecol 1996; 23: 136-40.

Kraus N, Ozdamar O, Heydemann PT, Stein L, Reed NL. Auditory brain-stem responses in hydrocephalic patients. Electroencephalogr Clin Neurophysiol 1984; 59(4): 310-7.

Lammer E, Chen D, Hoar R, Agnish N, Benk P, Braun J, et al. Retinoic acid embryopathy. N Engl J Med 1985; 313: 837. 
Le Marec B, Milon J, Catheline M, Cloarec L, Le Gall JY, Grall JY, et al. Abnormalities of the central nervous system. Results of 3 years of genetic counseling at the university hospital of Rennes: 192 cases. J Gynecol Obstet Biol Reprod (Paris) 1984; 13: 381-94.

Lolas F, Hoeppner T. Brainstem auditory evoked response (BAER): clinical perspectives and normative data. Acta Neurol Latinoamer 1977; 23: 175-87.

Macedo JCF, Suzuki FA, Felipe RG, Fukuda Y. Audiometria de tronco cerebral em indivíduos normais acima de 50 anos: estudo do tempo de latência comparativo entre os sexos. Pró-fono 1990; 2: 21-2.

Martinez-Frias ML. Epidemiological analysis of outcome od pregnancy in diabetic mothers: identification of the most characteristic and most freqüent congenital anomalies. Am J Med Genet 1994; 78: 140-5.

Matsunaga E, Shiota K. Holoprosencephaly in human embryos: epidemiologic studies of 150 cases. Teratology 1977; 16: 261-72.

Ming JE, Kaupas ME, Roessler E, Brunner HG, Golabi M, Tekin M, et al. Mutations in PATCHED-1, the receptor for sonic hedgehog are associated are associated with holoprosencephaly. Hum Genet 2002; 110: 297-301.

Ming JE, Muenke M. Holoprosencephaly: from homer to hedgehog. Clin Genet 1998; 53: $155-63$.

Ming JE, Muenke M. Multiple hits during early embryonic development. Digenic disease and holoprosencephaly. Am J Hum Genet 2002; 71: 10132. 
Ming PM, Goodner DM, Park TS. Cytogenetic variants in holoprosencephaly. Report of a case and review of the literature. Am J Dis Child 1976; 130: 864-7.

Moore KL, Persaud TVN. The developing human: clinically oriented embryology. Philadelphia: Saunders; 1998.

Muenke M, Beachy PA. Holoprosencephaly. In: Scriver CR, Beaudet AL, Sly WS, Valle D, Childs B, Kinzler KW, et al, editors. The metabolic and molecular bases of inherited disease. McGraw-Hill Companies, Inc; 2001. p. 6203-30.

Munhoz MSL, Silva MLG. Eletrofisiologia da audição: alguns aspectos sobre a anatomofisiologia da audição. RBM-ORL 1996; 3: 22-8.

Nagem Filho H, Moraes N, Rocha RGF. Contribuição para o estudo da prevalência das más formações congênitas lábio-palatais na população escolar de Bauru. Rev Fac Odont S Paulo 1968; 6(2): 111-28.

Nanni L, Ming JE, Bocian M, Steinhaus K, Bianchi DW, Die-Smulders, et al. The mutational spectrum of the sonic hedgehog gene in holoprosencephaly: SHH mutations cause a significant proportion of autosomal dominant holoprosencephaly. Hum Mol Genet 1999; 8: 2479-88.

Norman MG, McGillivray BC, Kalousek DK, Hill A, Poskitt KJ. Holoprosencephaly: defect of the mediobasal prosencephalon. Congenital malformations of the brain: pathological embryological, clinical, radiological and genetic aspects. New York: Oxford University Press; 1995.

Oliver G, Mailhos A, Wehr R, Copeland NG, Jenkins NA, Gruss P. Six3, a murine homologue of the sine oculis gene, demarcates the most anterior border of the 
developing neural plate and is expressed during eye development. Development 1995; 121: 4045-55.

Olsen CL, Hughes JP, Youngblood LG, Sharpe-Stimac M. Epidemiology of holoprosencephaly and phenotypic characteristics of affected children: New York state, 1984-1989. Am J Med Genet 1997; 73: 217-26.

Orioli IM, Castilla EE, Ming JE, Nazer J, Burle de Aguiar MJ, Llerena J, et al. Identification of novel mutations in SHH and ZIC2 in a south american (ECLAMC) population with holoprosencephaly. Hum Genet 2001; 109: 1-6.

Parant O, Sarramon MF, Delisle MB, Fournie A. Prenatal diagnosis of holoprosencephaly. A series of twelve cases. J Gynecol Obstet Biol Reprod (Paris) 1997; 26: 687-96.

Pasquier L, Dubourg C, Blayau M, Lazaro L, Le Marec B, David V, et al. A new mutation in the six-domain of SIX3 gene causes holoprosencephaly. Eur J Hum Genet 2000; 8: 797-800.

Pegoraro-Krook MI, Dutka-Souza JCR, Magalhães LCT, Feniman MR. Intervenção fonoaudiológica na fissura palatina. In: Ferreira LP, Befi-Lopes DM, Limongi SCO. Tratado de fonoaudiologia. São Paulo: Roca; 2004. p. 439-55.

Penrod JP. Logoaudiometria. In: Katz J. Tratado de audiologia clínica. São Paulo: Manole; 1999. p. 146-50.

Picton DW, Hillyard AS, Krausz HI, Galambos R. Human Auditory evoked potentials: I. Evaluation of the components. Electroencephalogr Clin Neurophysiol 1974; 36: 17990 . 
Pretorius DH, Russ PD, Rumack CM, Manco-Johnson ML. Diagnosis of brain neuropathology in utero. Neuroradiology 1986; 28: 386-97.

Ramana YV, Nanda V, Biswas G, Chittoria R, Ghosh S, Sharma RK. Audiological profile in older children and adolescents with unrepaired cleft palate. Cleft Palate Craniofac J 2005; 42(5): 570-3.

Roach E, Demyer W, Conneally PM, Palmer C, Merritt AD. Holoprosencephaly: birth data, genetic and demographic analyses of 30 families. Birth Defects Orig Artic Ser 1975; 11: 194-313.

Rodriguez TR, Hernandez MDJ, Martin FG, Goldwaig IM, Martinez HL. Variaciones fisiológicas de los potenciales evocados auditivos del tronco cerebral. Acta Otorrinolaring Esp 1989; 40: 133-5.

Roessler E, Belloni E, Gaudenz K, Jay P, Berta P, Scherer SW, et al. Mutations in the human sonic hedgehog gene cause holoprosencephaly. Nat Gen 1996; 14:357-60.

Roessler E, Belloni E, Gaudenz K, Vargas F, Scherer SW, Tsui LC, et al. Mutations in the C-terminal domain oh sonic hedgehog cause holoprosencephaly. Hum Mol Genet 1997; 6: 1847-53.

Roessler E, Du YZ, Mullor JL, Casas E, Allen WP, Gillessen-Kaesbach G, et al. Lossof-function mutations in the human GLI2 gene are associated with pituitary anomalies and holoprosencephaly-like features. Proc Natl Acad Sci USA 2003; 100: 13424-9.

Roessler E, Muenke M. Holoprosencephaly: a paradigm for the complex genetics of brain development. J Inherit Metab Dis 1998; 21: 481-97. 
Roessler E, Muenke M. How a hedgehog might see holoprosencephaly. Hum Mol Genet 2003; 12 (spec no. 1): R15-25.

Ronen GM. Holoprosencephaly and maternal low-calorie weight-reducing diet. Am $J$ Me Genet 1992; 42: 139.

Ronen GM, Andrews WL. Holoprosencephaly as a possible embryonic alcohol effect. Am J Med Genet 1991; 40: 151-4.

Rosa F. Holoprosencephaly and antiepileptic exposures. Teratology 1995; 51: 230.

Santiago G, Abramides DVM, De Vitto LPM, Ribeiro LA, Meira Jr SG, Richieri-Costa A. Language skills and neuropsychological performance in patients with SHH mutations and a holoprosencephaly-like phenotype. Am J Med Gen - part A 2006. (press)

Sequeira MLC, Fukuda Y. Auditory diagnosis: principles and applications. San Diego: Singular; 1997.

Sezgin I, Sungu S, Bekar E, Cetin M, Ceran H. Cyclopia-astomia-agnathiaholoprosencephaly association: a case report. Clin Dysmorphol 2002; 11: 225-6.

Sharma G, Heier L, Kalish RB, Troiano R, Chasen ST. Use of fetal magnetic resonance imaging in patients electing termination of pregnancy by dilation and evacuation. $\mathrm{Am} J$ Obstet Gynecol 2003; 189: 990-3.

Sheahan P, Blayney AW. Cleft palate and otitis media with effusion: a review. Rev Laryngol Otol Rhinol (Bord) 2003; 124(3): 171-7. 
Sheahan P, Blayney AW, Sheahan JN, Earley MJ. Sequelae of otitis media with effusion among children with cleft lip and/or cleft palate. Clin Otolaryngol Allied Sci 2002; 27(6):494-500.

Sheahan P, Miller I, Sheahan JN, Earley MJ, Blayney AW. Incidence and outcome of middle ear disease in cleft lip and/or cleft palate. Int J Ped Otorhinolaryngol 2003; 67: 785-93.

Sheahan P, Miller I, Sheahan JN, Earley MJ, Blayney AW. Long-term otological outcome of hamular fracture during palatoplasty. Otolaryngol Head Neck Surg 2004; 131(4): 445-51.

Shim YH, Bae SH, Kim JH, Kim KR, Kim CJ, Paik YK. A novel mutation of the human 7-dehydrocholesterol reductase gene reduces enzyme activity in patients with holoprosencephaly. Biochem Biophys Res Commun 2004; 315: 219-23.

Shiota K. Teratothanasia: prenatal loss of abnormal conceptuses and the prevalence of various malformations during human gestation. Birth Defects Orig Artic Ser 1993; 29: 189-99.

Shoda T, Murase M, Saheki S, Takeuchi N. A case of holoprosencephaly with a flat electroencephalogram. Rinsho Byori 1990; 38: 1201-5.

Siebert JR, Astley SJ, Clarren SK. Holoprosencephaly in a fetal macaque (macaca nemestrina) following weekly exposure to ethanol. Teratology 1991; 44: 29-36.

Siebert JR, Cohen Jr MM, Sulik KK, Shaw CM, Lemire RJ. Holoprosencephaly. An overview and atlas of cases. New York: Wiley-Liss; 1990.

Simon EM, Hevner RF, Pinter JD, Clegg NJ, Delgado M, Kinsman SL, et al. The middle interhemisferic variant of holoprosencephaly. Am J Neuroradiol 2002; 23: 1516. 
Sonigo PC, Rypens FF, Carteret M, Delezoide AL, Brunelle FO. MR imaging of fetal cerebral anomalies. Pediatr Radiol 1998; 28: 212-22.

Stapells DR, Picton DW, Smith AD. Normal hearing thresholds for clicks. J Acoust Soc Am 1982; 72: 74-9.

Stashinko EE, Clegg NJ, Kammann HA, Sweet VT, Delgado MR, Hahn JS, et al. A retrospective survey of perinatal risk factors of 104 living children with holoprosencephaly. Am J Med Genet 2004; 128A: 114-9.

Stockard JE, Stockard JJ, Westmoreland BF, Corfits JL. Brainstem auditory-evoked responses: normal variation as a functions of stimulus and subject characteristics. Arch Neurol 1979; 36: 823-31.

Sulik KK, Dehart DB, Rogers JM, Chernoff N. Teratogenicity of low doses of all-trans retinoic acid in presomite mouse embryos. Teratology 1995; 51: 398-403.

Sulik KK, Johnston MC. Embryonic origin of holoprosencephaly: interrelationship of the developing brain and face. San Electron Microsc 1982; 309-22.

Tallafuss A, Adolf B, Bally-Cuif L. Selective control of neuronal cluster size at the forebrain/ midbrain boundary by signaling from the prechordal plate. Dev Dyn 2003; 227: 524-35.

Toma P, Costa A, Magnano GM, Cariati M, Lituania M. Holoprosencephaly: prenatal diagnosis by sonography and magnetic resonance imaging. Prenat Diag 1990; 429-36.

Traggiai C, Stanhope R. Endocrinopathies associated with midline cerebral and cranial malformations. J Pediatr 2002; 140: 252-5.

Tuncbilek G, Ozgur F, Belgin E. Audiologic and tympanometric findings in children with cleft lip and palate. Cleft Palate Craniofac J 2003; 40(3): 304-9. 
Wallis DE, Muenke M. Molecular mechanisms of holoprosencephaly. Mol Genet Metab 1999; 68: 126-38.

Wallis DE, Roessler E, Hehr U, Nanni L, Wiltshire T, Richieri-Costa A, et al. Mutations in the homeodomain of the human SIX3 gene cause holoprosencephaly. Nat Genet 1999; 22: 196-8.

Yamada S, Uwabe C, Fujii S, Shiota K. Phenotypic variability in human embryonic holoprosencephaly in the Kyoto collection. Birth Defects Res Part A Clin Mol Teratol 2004; 70: 495-508.

Yantis PA. Avaliação dos limiares auditivos por via aérea. In: Katz J. Tratado de audiologia clínica. São Paulo: Manole; 1999. p. 97 -145. 

ANEXO 1 - Parecer do Comitê de Ética em Pesquisa do HRAC-USP, aprovando a realização deste estudo. 
Oficio $n^{\circ} 072 / 2006-U E P-C E P$

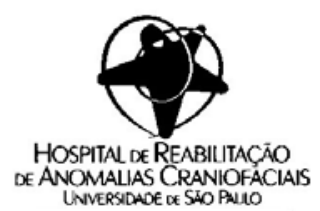

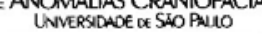

Unidade de Ensino e Pesquisa

Bauru, 03 de maio de 2006.

Prezado(a) Senhor(a)

O projeto de pesquisa intitulado "Avaliação do sistema auditivo periférico e central da holoprosencefalia.", de autoria de V.S ${ }^{a}$, foi aprovado pelo CEP em 23 de fevereiro de 2005. Em reunião realizada em 26/04/2006 a solicitação de alteração do título para "Potenciais evocados auditivos de tronco encefálico na holoprosencefalia.", foi aprovada.

Informamos que após o recebimento do trabalho concluído, este Comitê enviará um parecer final que poderá ser utilizado para publicação.

Atenciosamente

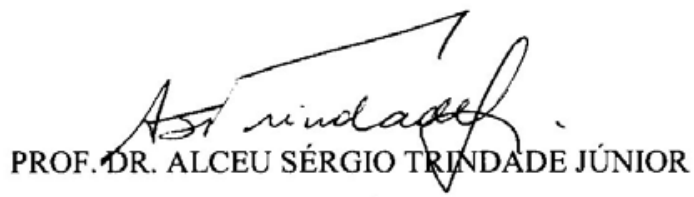

Coordenador do Comitê de Ética em Pesquisa do HRAC-USP

$\operatorname{Ilmo}(\mathrm{a}) \operatorname{Sr}(\mathrm{a})$

MELISSA ZATTONI ANTONELI

$\mathrm{A} / \mathrm{C}$

Dr. Antonio Richieri-Costa

Genética - HRAC/USP

Rua Silvio Marchione, 3-20 Bauru SP Brasil Caixa Postal 1501 CEP $17.012-900$ Tel. 551432358421 Fax: 551432347818 E-mail: anag@usp.br

\section{ANEXO 2 - Termo de Consentimento Livre e Esclarecido}

a) Termo de Consentimento Livre e Esclarecido (para adultos) 
Pelo presente instrumento que atende às exigências legais, o Sr. (a)

cédula de identidade , após leitura minuciosa da CARTA DE INFORMAÇÃO AO SUJEITO DA PESQUISA, devidamente explicada pelos profissionais em seus mínimos detalhes, ciente dos serviços e procedimentos aos quais será submetido, não restando quaisquer dúvidas a respeito do lido e explicado, firma seu CONSENTIMENTO LIVRE E ESCLARECIDO concordando em participar da pesquisa "Potenciais Evocados Auditivos de Tronco Encefálico na Holoprosencefalia”.

Fica claro que o sujeito da pesquisa ou seu representante legal pode, a qualquer momento, retirar seu CONSENTIMENTO LIVRE E ESCLARECIDO e deixar de participar desta pesquisa e ciente de que todas as informações prestadas tornaram-se confidenciais e guardadas por força de sigilo profissional (Art. $29^{\circ}$ do Código de Ética do Fonoaudiólogo).

Por estarem de acordo assinam o presente termo.

Bauru-SP, de de .

Assinatura do Sujeito da Pesquisa

Assinatura do Pesquisador

Nome do pesquisador responsável: Melissa Zattoni Antoneli

Endereço institucional: Rua Sílvio Marchione, 3-20, Bauru- SP, CEP: 17043-900

Tel: (14) 32358183

e-mail: melissafono@yahoo.com

ANEXO 2 - Termo de Consentimento Livre e Esclarecido

b) Termo de Consentimento Livre e Esclarecido (para crianças) 
Pelo presente instrumento que atende às exigências legais, o Sr. (a) , responsável pelo (a) menor , portador da cédula de identidade , após leitura minuciosa da CARTA DE INFORMAÇÃO AO SUJEITO DA PESQUISA, devidamente explicada pelos profissionais em seus mínimos detalhes, ciente dos serviços e procedimentos aos quais será submetido, não restando quaisquer dúvidas a respeito do lido e explicado, firma seu CONSENTIMENTO LIVRE E ESCLARECIDO concordando com a participação de seu filho(a) na pesquisa "Potenciais Evocados Auditivos de Tronco Encefálico na Holoprosencefalia".

Fica claro que o sujeito da pesquisa ou seu representante legal pode, a qualquer momento, retirar seu CONSENTIMENTO LIVRE E ESCLARECIDO e deixar de participar desta pesquisa e ciente de que todas as informações prestadas tornaram-se confidenciais e guardadas por força de sigilo profissional (Art. $29^{\circ}$ do Código de Ética do Fonoaudiólogo).

Por estarem de acordo assinam o presente termo.

Bauru-SP, de de .

Nome do pesquisador responsável: Melissa Zattoni Antoneli

Endereço institucional: Rua Sílvio Marchione, 3-20, Bauru- SP, CEP: 17043-900

Tel: (14) 32358183

e-mail: melissafono@yahoo.com 
Nós convidamos vocês a participarem do projeto de pesquisa do Hospital de Reabilitação de Anomalias Craniofaciais - HRAC/ USP Bauru intitulado "Potenciais Evocados Auditivos de Tronco Encefálico na Holoprosencefalia". Gostaríamos que soubessem que participar desta pesquisa é uma opção de vocês e no caso de não participarem ou desistirem a qualquer momento não haverá perda de qualquer benefício ou tratamento que estiverem fazendo nesta universidade.

Caso aceitem participar deste projeto de pesquisa gostaríamos que soubessem que:

a) Será realizada avaliação audiológica, incluindo os exames considerados pertinente à idade do paciente;

b) Será solicitada avaliação médica, psicológica ou de outros profissionais que se julgarem necessários para complementar o diagnóstico;

c) Os resultados deste estudo talvez não sejam de benefício imediato para o paciente ou para a família, mas assim que estiverem prontos estes serão disponibilizados para os mesmos;

d) Vocês estarão contribuindo com o estudo das principais manifestações audiológicas desta síndrome, podendo auxiliar demais indivíduos, familiares e profissionais;

e) Os resultados desta pesquisa poderão ser divulgados para fins científicos em revistas e congressos especializados na área, incluindo o uso de imagens, desde que sua identidade ou do seu filho (a) seja preservada;

f) Os resultados da avaliação serão disponibilizados nos prontuários do Setor de Genética do Hospital de Reabilitação de Anomalias Craniofaciais de Bauru.

Os 4 exames de audição que poderão ser realizados (audiometria, imitanciometria, emissões otoacústicas e BERA) não são invasivos e não causam nenhum tipo de desconforto (dor). É necessário, em média, de 1 hora a 1 hora e 30 minutos para a realização de todos os testes. No caso do exame BERA, é preciso que o paciente permaneça deitado e com a mínima movimentação possível. Dessa forma, em crianças pequenas, é realizado preferencialmente durante o sono natural. Nos casos em que isso não for possível, poderá ser indicada a sedação com hidrato de cloral, que é um sedativo administrado por via oral. Nesses casos, a dosagem será prescrita por um médico e o mesmo estará presente durante todo o exame.

Caso queiram apresentar reclamações em relação a sua participação na pesquisa, poderão entrar em contato com o Comitê de Ética em Pesquisa em Seres Humanos, do HRAC-USP, pelo endereço Rua Silvio Marchione, 3-20 na Unidade de Ensino e Pesquisa ou pelo telefone (14) $3235-8421$.

Bauru, _ _ _ _ Nome do paciente ou responsável:

Assinatura do paciente ou responsável:

Assinatura do pesquisador responsável:

ANEXO 4 - Valores de latência do PEATE em indivíduos normais, obtidos na etapa de calibração biológica. 


\begin{tabular}{|c|c|c|c|c|c|c|c|c|}
\hline $\mathrm{N}^{\mathrm{O}}$ & Lado & I & III & $\mathrm{V}$ & I-V & III-V & I-III & V i.a. \\
\hline \multirow[t]{2}{*}{1} & OD & 1,8 & 3,9 & 5,9 & 4,1 & 2,0 & 2,1 & \multirow[t]{2}{*}{0,2} \\
\hline & $\mathrm{OE}$ & 2,1 & 4,2 & 6,1 & 4,0 & 1,9 & 2,1 & \\
\hline \multirow[t]{2}{*}{2} & OD & 2,2 & 4,1 & 6,1 & 3,9 & 2,0 & 1,9 & \multirow[t]{2}{*}{0,2} \\
\hline & $\mathrm{OE}$ & 1,9 & 4,0 & 5,9 & 4,0 & 1,9 & 2,1 & \\
\hline \multirow[t]{2}{*}{3} & OD & 1,9 & 4,0 & 5,9 & 4,0 & 1,9 & 2,1 & \multirow[t]{2}{*}{0,2} \\
\hline & $\mathrm{OE}$ & 1,9 & 4,1 & 6,1 & 4,2 & 2,0 & 2,2 & \\
\hline \multirow[t]{2}{*}{4} & OD & 2,1 & 4,0 & 6,1 & 4,0 & 2,1 & 1,9 & \multirow[t]{2}{*}{0,3} \\
\hline & $\mathrm{OE}$ & 1,8 & 4,0 & 5,8 & 4,0 & 1,8 & 2,2 & \\
\hline \multirow[t]{2}{*}{5} & OD & 1,9 & 4,0 & 5,9 & 4,0 & 1,9 & 2,1 & \multirow[t]{2}{*}{0,2} \\
\hline & $\mathrm{OE}$ & 2,0 & 4,1 & 6,0 & 4,0 & 1,9 & 2,1 & \\
\hline \multirow[t]{2}{*}{6} & OD & 1,8 & 3,7 & 5,6 & 3,8 & 1,9 & 1,9 & \multirow[t]{2}{*}{0,2} \\
\hline & $\mathrm{OE}$ & 1,9 & 3,9 & 5,8 & 3,9 & 1,9 & 2,0 & \\
\hline \multirow[t]{2}{*}{7} & OD & 1,8 & 3,8 & 5,5 & 3,7 & 1,7 & 2,0 & \multirow[t]{2}{*}{0,3} \\
\hline & $\mathrm{OE}$ & 1,8 & 3,9 & 5,8 & 4,0 & 1,9 & 2,1 & \\
\hline \multirow[t]{2}{*}{8} & OD & 1,9 & 4,0 & 5,6 & 3,7 & 1,6 & 2,1 & \multirow[t]{2}{*}{0,1} \\
\hline & $\mathrm{OE}$ & 1,8 & 3,8 & 5,7 & 3,9 & 2,0 & 1,9 & \\
\hline \multirow[t]{2}{*}{9} & OD & 1,8 & 3,9 & 5,7 & 3,9 & 1,8 & 2,1 & \multirow[t]{2}{*}{0,0} \\
\hline & $\mathrm{OE}$ & 1,8 & 3,8 & 5,7 & 3,9 & 1,9 & 2,0 & \\
\hline \multirow[t]{2}{*}{10} & OD & 2,0 & 4,0 & 5,9 & 3,9 & 2,0 & 1,9 & \multirow[t]{2}{*}{0,3} \\
\hline & $\mathrm{OE}$ & 2,0 & 4,0 & 5,6 & 3,6 & 1,6 & 2,0 & \\
\hline
\end{tabular}

ANEXO 5 - Caracterização dos indivíduos dos grupos experimentais (GH e GHL)

\begin{tabular}{|c|c|c|c|c|c|}
\hline $\mathrm{N}^{\mathrm{o}}$ & Sexo & Idade & Mutação & HPE & Queixa Auditiva \\
\hline $\mathbf{1}$ & $\mathrm{F}$ & $2 \mathrm{a}$ & - & $\mathrm{SL}$ & Nega \\
\hline
\end{tabular}




\begin{tabular}{|c|c|c|c|c|c|}
\hline 2 & $\mathrm{~F}$ & $1 \mathrm{a} 7 \mathrm{~m}$ & SHH & SL & Nega \\
\hline 3 & $\mathrm{~F}$ & $14 \mathrm{a}$ & GLI2 & $\mathrm{L}$ & Nega \\
\hline 4 & M & $3 a$ & - & $\mathrm{AL}$ & Mãe referiu dúvidas \\
\hline 5 & M & $5 \mathrm{a}$ & SHH & SL & Histórico de otites \\
\hline 6 & $\mathrm{~F}$ & $3 a$ & - & $\mathrm{AL}$ & Histórico de otites \\
\hline 7 & $\mathrm{M}$ & $1 \mathrm{a} 6 \mathrm{~m}$ & - & $\mathrm{AL}$ & Nega \\
\hline 8 & $\mathrm{~F}$ & $2 a$ & SIX3 & $\mathrm{AL}$ & Nega \\
\hline 9 & M & $1 \mathrm{a} 8 \mathrm{~m}$ & SIX3 & $\mathrm{AL}$ & Histórico de otites \\
\hline 10 & $\mathrm{~F}$ & $6 a$ & - & SL & Histórico de otites e microcirurgia \\
\hline 11 & $\mathrm{~F}$ & $5 a$ & SIX3 & $\mathrm{AL}$ & Mãe referiu dúvidas \\
\hline 12 & $\mathrm{M}$ & $3 a$ & - & $\mathrm{L}$ & Histórico de otites \\
\hline 13 & $\mathrm{~F}$ & $2 \mathrm{a}$ & - & $\mathrm{AL}$ & Nega \\
\hline 14 & $\mathrm{~F}$ & $5 a$ & - & Like & Nega \\
\hline 15 & $\mathrm{~F}$ & $22 \mathrm{a}$ & - & Like & Nega \\
\hline 16 & $\mathrm{~F}$ & $22 \mathrm{a}$ & - & Like & Nega \\
\hline 17 & $\mathrm{M}$ & 9 & - & Like & Nega \\
\hline 18 & $\mathrm{~F}$ & $6 a$ & - & Like & Histórico de otites \\
\hline 19 & $\mathrm{~F}$ & $5 a$ & - & Like & Nega \\
\hline 20 & $\mathrm{~F}$ & $3 a$ & SHH & Like & Histórico de otites \\
\hline 21 & $\mathrm{~F}$ & $13 a$ & - & Like & Nega \\
\hline 22 & $\mathrm{~F}$ & $7 \mathrm{a}$ & GLI2 & Like & Nega \\
\hline 23 & $\mathrm{~F}$ & $19 a$ & SHH & Like & Nega \\
\hline 24 & $\mathrm{~F}$ & $2 a$ & - & Like & Nega \\
\hline 25 & $\mathrm{M}$ & $15 \mathrm{a}$ & SHH & Like & Nega \\
\hline 26 & $\mathrm{~F}$ & $16 \mathrm{a}$ & - & Like & Nega \\
\hline 27 & $\mathrm{~F}$ & $9 a$ & - & Like & Nega \\
\hline 28 & M & $9 a$ & SHH & Like & Nega \\
\hline 29 & $\mathrm{~F}$ & $4 a$ & PTCH & Like & Nega \\
\hline 30 & $\mathrm{~F}$ & $12 \mathrm{a}$ & - & Like & Nega \\
\hline 31 & $\mathrm{~F}$ & $7 a$ & - & Like & Nega \\
\hline 32 & $\mathrm{~F}$ & $4 a$ & - & Like & Nega \\
\hline 33 & $\mathrm{~F}$ & $8 a$ & - & Like & Nega \\
\hline 34 & M & $13 a$ & - & Like & Nega \\
\hline 35 & $\mathrm{M}$ & $3 a$ & - & Like & Nega \\
\hline
\end{tabular}

Legenda:
$\mathrm{AL}=$ alobar
$\mathrm{SL}=$ semilobar
$\mathrm{L}=$ lobar

ANEXO 6 - Caracterização dos indivíduos do grupo controle (GC)

\begin{tabular}{|c|c|c|}
\hline $\mathrm{N}^{\mathrm{o}}$ & Sexo & Idade \\
\hline $\mathbf{1}$ & $\mathrm{M}$ & $1 \mathrm{a} 6 \mathrm{~m}$ \\
\hline
\end{tabular}




\begin{tabular}{|c|c|c|}
\hline $\mathbf{2}$ & $\mathrm{F}$ & $1 \mathrm{a} 7 \mathrm{~m}$ \\
\hline $\mathbf{3}$ & $\mathrm{M}$ & $1 \mathrm{a} 8 \mathrm{~m}$ \\
\hline $\mathbf{4}$ & $\mathrm{F}$ & $2 \mathrm{a}$ \\
\hline $\mathbf{5}$ & $\mathrm{F}$ & $3 \mathrm{a}$ \\
\hline $\mathbf{6}$ & $\mathrm{M}$ & $3 \mathrm{a}$ \\
\hline $\mathbf{7}$ & $\mathrm{F}$ & $4 \mathrm{a}$ \\
\hline $\mathbf{8}$ & $\mathrm{F}$ & $5 \mathrm{a}$ \\
\hline $\mathbf{9}$ & $\mathrm{M}$ & $5 \mathrm{a}$ \\
\hline $\mathbf{1 0}$ & $\mathrm{F}$ & $6 \mathrm{a}$ \\
\hline $\mathbf{1 1}$ & $\mathrm{F}$ & $7 \mathrm{a}$ \\
\hline $\mathbf{1 2}$ & $\mathrm{F}$ & $8 \mathrm{a}$ \\
\hline $\mathbf{1 3}$ & $\mathrm{F}$ & $9 \mathrm{a}$ \\
\hline $\mathbf{1 4}$ & $\mathrm{M}$ & $9 \mathrm{a}$ \\
\hline $\mathbf{1 5}$ & $\mathrm{F}$ & $12 \mathrm{a}$ \\
\hline $\mathbf{1 6}$ & $\mathrm{F}$ & $13 \mathrm{a}$ \\
\hline $\mathbf{1 7}$ & $\mathrm{M}$ & $13 \mathrm{a}$ \\
\hline $\mathbf{1 8}$ & $\mathrm{F}$ & $14 \mathrm{a}$ \\
\hline $\mathbf{1 9}$ & $\mathrm{M}$ & $15 \mathrm{a}$ \\
\hline $\mathbf{2 0}$ & $\mathrm{F}$ & $16 \mathrm{a}$ \\
\hline $\mathbf{2 1}$ & $\mathrm{F}$ & $19 \mathrm{a}$ \\
\hline $\mathbf{2 2}$ & $\mathrm{F}$ & $22 \mathrm{a}$ \\
\hline & & \\
\hline
\end{tabular}

ANEXO 7 - Limiares (em dB) por via aérea da ATL e Logoaudiometria nos indivíduos do GHL que responderam ao exame. 


\begin{tabular}{|c|c|c|c|c|c|c|c|c|c|c|c|}
\hline $\mathbf{N}^{\mathbf{o}}$ & Lado & 250 & 500 & $1 K$ & $2 K$ & $3 K$ & $4 K$ & $6 K$ & $8 K$ & SRT-dB & IRF- \% \\
\hline \multirow[t]{2}{*}{1} & OD & 15 & 15 & 15 & 5 & 15 & 15 & 5 & 5 & 10 & 96 \\
\hline & $\mathrm{OE}$ & 15 & 15 & 10 & 15 & 20 & 20 & 20 & 20 & 15 & 96 \\
\hline \multirow[t]{2}{*}{2} & OD & 15 & 10 & 5 & 0 & 0 & 0 & 0 & 5 & 10 & 96 \\
\hline & $\mathrm{OE}$ & 15 & 15 & 10 & 5 & 5 & 5 & 15 & 5 & 10 & 92 \\
\hline \multirow[t]{2}{*}{3} & OD & 5 & 10 & 5 & 5 & 15 & 5 & 5 & 10 & 5 & 92 \\
\hline & $\mathrm{OE}$ & 5 & 5 & 5 & 5 & 10 & 5 & 15 & 15 & 5 & 96 \\
\hline \multirow[t]{2}{*}{4} & OD & 15 & 15 & 10 & 5 & 5 & 5 & 15 & 20 & 15 & 96 \\
\hline & $\mathrm{OE}$ & 15 & 15 & 10 & 5 & 0 & 5 & 20 & 15 & 15 & 92 \\
\hline \multirow[t]{2}{*}{5} & OD & 30 & 15 & 15 & 10 & 10 & 10 & 25 & 15 & 20 & 92 \\
\hline & $\mathrm{OE}$ & 20 & 15 & 10 & 5 & 5 & 5 & 10 & 5 & 15 & 92 \\
\hline \multirow[t]{2}{*}{6} & OD & 15 & 10 & 0 & 10 & 5 & 5 & 20 & 20 & 10 & 96 \\
\hline & $\mathrm{OE}$ & 15 & 15 & 5 & 5 & 10 & 5 & 15 & 15 & 10 & 92 \\
\hline \multirow[t]{2}{*}{7} & OD & - & 40 & 35 & 35 & - & 20 & - & - & 30 & - \\
\hline & $\mathrm{OE}$ & - & 30 & 30 & 25 & - & 25 & - & - & 30 & - \\
\hline \multirow[t]{2}{*}{8} & OD & 20 & 15 & 20 & 10 & 10 & 30 & 25 & 30 & 20 & 100 \\
\hline & $\mathrm{OE}$ & 10 & 15 & 0 & 5 & 0 & 10 & 20 & 20 & 5 & 96 \\
\hline \multirow[t]{2}{*}{10} & OD & 15 & 15 & 5 & 15 & 10 & 5 & 15 & 15 & 15 & 96 \\
\hline & $\mathrm{OE}$ & 15 & 10 & 5 & 10 & 10 & 0 & 5 & 5 & 10 & 100 \\
\hline \multirow[t]{2}{*}{12} & OD & 20 & 20 & 15 & 5 & 0 & 0 & 5 & 10 & 15 & 100 \\
\hline & $\mathrm{OE}$ & 20 & 20 & 15 & 0 & 5 & 15 & 5 & 15 & 15 & 100 \\
\hline \multirow[t]{2}{*}{13} & OD & 10 & 5 & 5 & 0 & 0 & 0 & 0 & 0 & 5 & 100 \\
\hline & $\mathrm{OE}$ & 5 & 5 & 0 & 0 & 0 & 0 & 0 & 0 & 0 & 96 \\
\hline \multirow[t]{2}{*}{14} & OD & 15 & 15 & 10 & 5 & 5 & 15 & 10 & 10 & 10 & 100 \\
\hline & $\mathrm{OE}$ & 20 & 20 & 5 & 10 & 5 & 10 & 15 & 15 & 15 & 96 \\
\hline \multirow[t]{2}{*}{15} & OD & 15 & 5 & 5 & 10 & 15 & 5 & 5 & 5 & 5 & 100 \\
\hline & $\mathrm{OE}$ & 15 & 15 & 10 & 10 & 15 & 10 & 10 & 15 & 10 & 96 \\
\hline \multirow[t]{2}{*}{16} & OD & - & 5 & 5 & 10 & 5 & 0 & - & - & 10 & 92 \\
\hline & $\mathrm{OE}$ & - & 10 & 10 & 5 & 10 & 5 & - & - & 15 & 92 \\
\hline \multirow[t]{2}{*}{17} & OD & 15 & 20 & 25 & 15 & 10 & 10 & 25 & 15 & 25 & 96 \\
\hline & $\mathrm{OE}$ & 10 & 5 & 5 & 0 & 0 & 10 & 15 & 10 & 10 & 100 \\
\hline \multirow[t]{2}{*}{18} & OD & 15 & 10 & 5 & 5 & 15 & 5 & 0 & 10 & 5 & 96 \\
\hline & $\mathrm{OE}$ & 15 & 15 & 10 & 10 & 5 & 5 & 15 & 15 & 10 & 96 \\
\hline \multirow[t]{2}{*}{20} & OD & 40 & 30 & 25 & 15 & 15 & 25 & 15 & 25 & 30 & - \\
\hline & $\mathrm{OE}$ & 35 & 35 & 25 & 15 & 15 & 25 & 20 & 20 & 25 & - \\
\hline \multirow[t]{2}{*}{21} & OD & 5 & 10 & 10 & 5 & 5 & 10 & 5 & 5 & 10 & 100 \\
\hline & $\mathrm{OE}$ & 5 & 10 & 10 & 5 & 5 & 0 & 0 & 0 & 10 & 96 \\
\hline
\end{tabular}

ANEXO 8 - Limiares (em dB) por via aérea da ATL e Logoaudiometria nos indivíduos do GC que responderam ao exame. 


\begin{tabular}{|c|c|c|c|c|c|c|c|c|c|c|c|}
\hline $\mathbf{N}^{\mathbf{0}}$ & Lado & 250 & 500 & $1 K$ & $2 K$ & $3 K$ & $4 K$ & $6 K$ & $8 K$ & SRT- dB & IRF- \% \\
\hline \multirow[t]{2}{*}{5} & OD & - & 10 & 5 & 5 & 10 & 10 & - & - & 10 & - \\
\hline & $\mathrm{OE}$ & - & 15 & 15 & 10 & 10 & 5 & - & - & 20 & - \\
\hline \multirow[t]{2}{*}{6} & OD & - & 5 & 5 & 10 & 5 & 5 & - & - & 10 & - \\
\hline & $\mathrm{OE}$ & - & 5 & 10 & 5 & 10 & 10 & - & - & 15 & - \\
\hline \multirow[t]{2}{*}{7} & OD & 5 & 10 & 10 & 15 & 15 & 5 & 5 & 10 & 15 & 92 \\
\hline & $\mathrm{OE}$ & 10 & 15 & 15 & 10 & 5 & 5 & 5 & 5 & 15 & 96 \\
\hline \multirow[t]{2}{*}{8} & OD & 5 & 0 & 0 & 5 & 10 & 10 & 5 & 0 & 5 & 96 \\
\hline & $\mathrm{OE}$ & 5 & 5 & 5 & 10 & 5 & 0 & 0 & 5 & 10 & 100 \\
\hline \multirow[t]{2}{*}{9} & OD & 10 & 10 & 15 & 15 & 10 & 15 & 10 & 10 & 20 & 96 \\
\hline & $\mathrm{OE}$ & 5 & 10 & 10 & 5 & 5 & 15 & 15 & 15 & 10 & 92 \\
\hline \multirow[t]{2}{*}{10} & OD & 10 & 10 & 5 & 5 & 0 & 10 & 10 & 10 & 10 & 96 \\
\hline & $\mathrm{OE}$ & 5 & 0 & 0 & 10 & 5 & 5 & 5 & 15 & 5 & 96 \\
\hline \multirow[t]{2}{*}{11} & OD & 5 & 5 & 5 & 10 & 15 & 10 & 10 & 5 & 10 & 92 \\
\hline & $\mathrm{OE}$ & 10 & 5 & 10 & 15 & 10 & 5 & 5 & 5 & 15 & 100 \\
\hline \multirow[t]{2}{*}{12} & OD & 5 & 0 & 0 & 5 & 10 & 5 & 10 & 10 & 5 & 100 \\
\hline & $\mathrm{OE}$ & 5 & 5 & 10 & 5 & 5 & 10 & 5 & 5 & 10 & 100 \\
\hline \multirow[t]{2}{*}{13} & OD & 5 & 10 & 15 & 15 & 10 & 5 & 5 & 15 & 15 & 96 \\
\hline & $\mathrm{OE}$ & 10 & 15 & 10 & 5 & 5 & 5 & 15 & 20 & 15 & 96 \\
\hline \multirow[t]{2}{*}{14} & OD & 10 & 10 & 5 & 5 & 10 & 15 & 10 & 5 & 15 & 100 \\
\hline & $\mathrm{OE}$ & 15 & 15 & 10 & 5 & 10 & 10 & 10 & 5 & 15 & 100 \\
\hline \multirow[t]{2}{*}{15} & OD & 15 & 10 & 10 & 10 & 15 & 5 & 10 & 10 & 15 & 100 \\
\hline & $\mathrm{OE}$ & 10 & 5 & 5 & 10 & 5 & 15 & 15 & 10 & 10 & 96 \\
\hline \multirow[t]{2}{*}{16} & OD & 5 & 0 & 0 & 5 & 5 & 5 & 10 & 5 & 5 & 96 \\
\hline & $\mathrm{OE}$ & 0 & 0 & 5 & 10 & 5 & 5 & 10 & 10 & 10 & 100 \\
\hline \multirow[t]{2}{*}{17} & OD & 10 & 10 & 5 & 15 & 15 & 15 & 10 & 10 & 15 & 92 \\
\hline & $\mathrm{OE}$ & 5 & 5 & 10 & 15 & 15 & 10 & 15 & 10 & 10 & 100 \\
\hline \multirow[t]{2}{*}{18} & OD & 15 & 10 & 10 & 5 & 10 & 15 & 10 & 5 & 10 & 92 \\
\hline & $\mathrm{OE}$ & 10 & 5 & 5 & 5 & 10 & 15 & 15 & 10 & 5 & 96 \\
\hline \multirow[t]{2}{*}{19} & OD & 5 & 0 & 5 & 5 & 0 & 0 & 5 & 10 & 5 & 100 \\
\hline & $\mathrm{OE}$ & 0 & 0 & 5 & 0 & 5 & 10 & 5 & 5 & 5 & 100 \\
\hline \multirow[t]{2}{*}{20} & OD & 10 & 10 & 5 & 5 & 5 & 15 & 10 & 15 & 10 & 96 \\
\hline & $\mathrm{OE}$ & 5 & 10 & 10 & 5 & 10 & 15 & 15 & 10 & 10 & 96 \\
\hline \multirow[t]{2}{*}{21} & OD & 5 & 5 & 5 & 10 & 10 & 15 & 15 & 10 & 10 & 100 \\
\hline & $\mathrm{OE}$ & 5 & 0 & 0 & 5 & 10 & 15 & 15 & 15 & 10 & 96 \\
\hline \multirow[t]{2}{*}{22} & OD & 10 & 15 & 10 & 5 & 5 & 10 & 10 & 10 & 10 & 100 \\
\hline & $\mathrm{OE}$ & 5 & 10 & 10 & 15 & 10 & 5 & 10 & 5 & 15 & 100 \\
\hline
\end{tabular}

ANEXO 9 - Resultados da Imitanciometria no GH

\begin{tabular}{|l|l|l|}
$\mathrm{N}^{\mathrm{o}}$ & Orelha & $\begin{array}{l}\text { Timpanometria } \\
\text { (tipo de curva) }\end{array}$
\end{tabular}




\begin{tabular}{|c|c|c|c|}
\hline \multirow[t]{2}{*}{1} & OD & $\mathrm{B}$ & Ausentes \\
\hline & $\mathrm{OE}$ & B & Ausentes \\
\hline \multirow[t]{2}{*}{2} & OD & $\mathrm{B}$ & Ausentes \\
\hline & $\mathrm{OE}$ & $\mathrm{B}$ & Ausentes \\
\hline \multirow[t]{2}{*}{3} & OD & $\mathrm{Ar}$ & Presentes \\
\hline & $\mathrm{OE}$ & $\mathrm{Ar}$ & Presentes \\
\hline \multirow[t]{2}{*}{4} & OD & $\mathrm{Ar}$ & Presentes \\
\hline & $\mathrm{OE}$ & $\mathrm{C}$ & Presentes \\
\hline \multirow[t]{2}{*}{5} & OD & A & Não realizados* \\
\hline & $\mathrm{OE}$ & A & Não realizados* \\
\hline \multirow[t]{2}{*}{6} & OD & $\mathrm{B}$ & Ausentes \\
\hline & $\mathrm{OE}$ & B & Ausentes \\
\hline \multirow[t]{2}{*}{7} & OD & $\mathrm{C}$ & Não realizados* \\
\hline & $\mathrm{OE}$ & $\mathrm{C}$ & Não realizados* \\
\hline \multirow[t]{2}{*}{8} & OD & $\mathrm{A}$ & Não realizados* \\
\hline & $\mathrm{OE}$ & A & Não realizados* \\
\hline \multirow[t]{2}{*}{9} & OD & B & Ausentes \\
\hline & $\mathrm{OE}$ & B & Ausentes \\
\hline \multirow[t]{2}{*}{10} & OD & $\mathrm{C}$ & Não realizados* \\
\hline & $\mathrm{OE}$ & $\mathrm{C}$ & Não realizados* \\
\hline \multirow[t]{2}{*}{11} & OD & $\mathrm{B}$ & Ausentes \\
\hline & $\mathrm{OE}$ & B & Ausentes \\
\hline \multirow[t]{2}{*}{12} & OD & $\mathrm{B}$ & Ausentes \\
\hline & $\mathrm{OE}$ & $\mathrm{B}$ & Ausentes \\
\hline \multirow[t]{2}{*}{13} & OD & $\mathrm{C}$ & Não realizados* \\
\hline & $\mathrm{OE}$ & $\mathrm{C}$ & Não realizados* \\
\hline
\end{tabular}

* reflexos não pesquisados por falta de colaboração do paciente.

ANEXO 10 - Resultados da Imitanciometria no GHL

\begin{tabular}{|c|c|c|c|}
\hline $\mathrm{N}^{\mathrm{o}}$ & Orelha & $\begin{array}{c}\text { Timpanometria } \\
\text { (tipo de curva) }\end{array}$ & Reflexos \\
\hline $\mathbf{1}$ & OD & A & Presentes \\
\hline
\end{tabular}




\begin{tabular}{|c|c|c|c|}
\hline & $\mathrm{OE}$ & A & Presentes \\
\hline \multirow[t]{2}{*}{2} & OD & A & Presentes \\
\hline & $\mathrm{OE}$ & A & Presentes \\
\hline \multirow[t]{2}{*}{3} & OD & A & Presentes \\
\hline & $\mathrm{OE}$ & A & Presentes \\
\hline \multirow[t]{2}{*}{4} & OD & $\mathrm{C}$ & Ausentes \\
\hline & $\mathrm{OE}$ & $\mathrm{C}$ & Ausentes \\
\hline \multirow[t]{2}{*}{5} & OD & $\mathrm{C}$ & Presentes \\
\hline & $\mathrm{OE}$ & A & Presentes \\
\hline \multirow[t]{2}{*}{6} & OD & $\mathrm{Ad}$ & Presentes \\
\hline & $\mathrm{OE}$ & $\mathrm{Ad}$ & Presentes \\
\hline \multirow[t]{2}{*}{7} & OD & B & Ausentes \\
\hline & $\mathrm{OE}$ & B & Ausentes \\
\hline \multirow[t]{2}{*}{8} & OD & $\mathrm{C}$ & Ausentes \\
\hline & $\mathrm{OE}$ & A & Presentes \\
\hline \multirow[t]{2}{*}{9} & OD & A & Presentes \\
\hline & $\mathrm{OE}$ & A & Presentes \\
\hline \multirow[t]{2}{*}{10} & OD & $\mathrm{Ad}$ & Presentes \\
\hline & $\mathrm{OE}$ & $\mathrm{Ad}$ & Presentes \\
\hline \multirow[t]{2}{*}{11} & OD & A & Presentes \\
\hline & $\mathrm{OE}$ & $\mathrm{C}$ & Ausentes \\
\hline \multirow[t]{2}{*}{12} & OD & $\mathrm{C}$ & Ausentes \\
\hline & $\mathrm{OE}$ & $\mathrm{C}$ & Ausentes \\
\hline \multirow[t]{2}{*}{13} & OD & A & Presentes \\
\hline & $\mathrm{OE}$ & A & Presentes \\
\hline \multirow[t]{2}{*}{14} & OD & $\mathrm{Ad}$ & Presentes \\
\hline & $\mathrm{OE}$ & A & Presentes \\
\hline \multirow[t]{2}{*}{15} & OD & A & Presentes \\
\hline & $\mathrm{OE}$ & $\mathrm{Ad}$ & Presentes \\
\hline \multirow[t]{2}{*}{16} & OD & A & Presentes \\
\hline & $\mathrm{OE}$ & $\mathrm{Ad}$ & Presentes \\
\hline \multirow[t]{2}{*}{17} & OD & $\mathrm{C}$ & Presentes \\
\hline & $\mathrm{OE}$ & A & Presentes \\
\hline \multirow[t]{2}{*}{18} & OD & A & Presentes \\
\hline & $\mathrm{OE}$ & A & Presentes \\
\hline \multirow[t]{2}{*}{19} & OD & A & Presentes \\
\hline & $\mathrm{OE}$ & A & Presentes \\
\hline \multirow[t]{2}{*}{20} & OD & $\mathrm{C}$ & Presentes \\
\hline & $\mathrm{OE}$ & $\mathrm{C}$ & Presentes \\
\hline \multirow[t]{2}{*}{21} & OD & A & Presentes \\
\hline & $\mathrm{OE}$ & A & Presentes \\
\hline \multirow[t]{2}{*}{22} & OD & B & Ausentes \\
\hline & $\mathrm{OE}$ & B & Ausentes \\
\hline
\end{tabular}

ANEXO 11 - Resultados do PEATE (latências em ms) no GH 


\begin{tabular}{|c|c|c|c|c|c|c|c|c|}
\hline $\mathrm{N}^{\mathrm{O}}$ & Orelha & I & III & $\mathrm{V}$ & I-V & III-V & I-III & $\mathrm{V}$ i.a. \\
\hline \multirow[t]{2}{*}{1} & OD & 2,3 & 4,3 & 6,3 & 4,0 & 2,0 & 2,0 & \multirow[t]{2}{*}{0} \\
\hline & $\mathrm{OE}$ & 2,4 & 4,3 & 6,3 & 3,9 & 2,0 & 1,9 & \\
\hline \multirow[t]{2}{*}{2} & OD & 2,5 & 4,4 & 6,5 & 4,0 & 2,1 & 1,9 & \multirow[t]{2}{*}{0,1} \\
\hline & $\mathrm{OE}$ & 2,3 & 4,1 & 6,4 & 4,0 & 2,1 & 1,9 & \\
\hline \multirow[t]{2}{*}{3} & OD & 2,2 & 4,1 & 6,0 & 3,8 & 1,9 & 1,9 & \multirow[t]{2}{*}{0} \\
\hline & $\mathrm{OE}$ & 2,2 & 4,1 & 6,0 & 3,8 & 1,9 & 1,9 & \\
\hline \multirow[t]{2}{*}{4} & OD & 2,0 & 5,0 & 7,4 & 5,4 & 2,4 & 3,0 & \multirow[t]{2}{*}{0,1} \\
\hline & $\mathrm{OE}$ & 2,0 & 5,3 & 7,5 & 5,5 & 2,2 & 3,3 & \\
\hline \multirow[t]{2}{*}{5} & OD & 2,0 & 4,1 & 6,1 & 4,1 & 2,1 & 2,0 & \multirow[t]{2}{*}{, } \\
\hline & $\mathrm{OE}$ & 2,0 & 4,1 & 6,1 & 4,1 & 2,1 & 2,0 & \\
\hline \multirow[t]{2}{*}{6} & OD & 2,4 & 4,3 & 6,3 & 3,9 & 2,0 & 1,9 & \multirow[t]{2}{*}{0,1} \\
\hline & $\mathrm{OE}$ & 2,4 & 4,3 & 6,2 & 3,8 & 1,9 & 1,9 & \\
\hline \multirow[t]{2}{*}{7} & OD & 2,0 & 4,0 & - & - & - & 2,0 & \multirow[t]{2}{*}{ - } \\
\hline & $\mathrm{OE}$ & 2,2 & 4,6 & - & - & - & 2,4 & \\
\hline \multirow[t]{2}{*}{8} & OD & 1,8 & 3,8 & 5,9 & 4,1 & 2,1 & 2,0 & \multirow[t]{2}{*}{0} \\
\hline & $\mathrm{OE}$ & 1,8 & 4,0 & 5,9 & 4,1 & 1,9 & 2,2 & \\
\hline \multirow[t]{2}{*}{9} & OD & 2,4 & 4,5 & 6,8 & 4,4 & 2,3 & 2,1 & \multirow[t]{2}{*}{0,1} \\
\hline & $\mathrm{OE}$ & 2,6 & 4,7 & 6,9 & 4,3 & 2,2 & 2,1 & \\
\hline \multirow[t]{2}{*}{10} & OD & 2,5 & 4,6 & 6,4 & 3,9 & 2,2 & 2,1 & \\
\hline & $\mathrm{OE}$ & 1,8 & 5,7 & - & - & - & 3,9 & \\
\hline \multirow[t]{2}{*}{11} & OD & 2,1 & 4,6 & 6,7 & 4,6 & 2,1 & 2,5 & \multirow[t]{2}{*}{0,5} \\
\hline & $\mathrm{OE}$ & 2,6 & 4,9 & 7,2 & 4,6 & 2,3 & 2,3 & \\
\hline \multirow[t]{2}{*}{12} & OD & 2,5 & 4,5 & 6,6 & 4,1 & 2,1 & 2,0 & \multirow[t]{2}{*}{0,1} \\
\hline & $\mathrm{OE}$ & 2,3 & 4,4 & 6,5 & 4,2 & 2,1 & 2,1 & \\
\hline \multirow[t]{2}{*}{13} & $\mathrm{OD}$ & 1,9 & 4,3 & - & - & - & 2,4 & \\
\hline & $\mathrm{OE}$ & 1,9 & 4,3 & - & - & & 2,4 & \\
\hline
\end{tabular}

ANEXO 12- Resultados do PEATE no GHL (latências em ms) 


\begin{tabular}{|c|c|c|c|c|c|c|c|c|}
\hline $\mathrm{N}^{\mathrm{o}}$ & Orelha & I & III & V & I-V & III-V & I-III & V i.a. \\
\hline \multirow[t]{2}{*}{1} & OD & 1,8 & 3,9 & 5,7 & 3,9 & 1,8 & 2,1 & \multirow{2}{*}{0,1} \\
\hline & $\mathrm{OE}$ & 1,8 & 3,9 & 5,8 & 4,0 & 1,9 & 2,1 & \\
\hline \multirow[t]{2}{*}{2} & OD & 2,3 & 4,4 & 6,3 & 4,0 & 1,9 & 2,1 & \multirow[t]{2}{*}{0,1} \\
\hline & $\mathrm{OE}$ & 2,4 & 4,4 & 6,4 & 4,0 & 2,0 & 2,0 & \\
\hline \multirow[t]{2}{*}{3} & OD & 1,9 & 3,8 & 5,8 & 3,9 & 2,0 & 1,9 & \multirow[t]{2}{*}{0} \\
\hline & $\mathrm{OE}$ & 1,9 & 4,0 & 5,8 & 3,9 & 1,8 & 2,1 & \\
\hline \multirow[t]{2}{*}{4} & OD & 2,0 & 4,0 & 6,0 & 4,0 & 2,0 & 2,0 & \multirow[t]{2}{*}{0,1} \\
\hline & $\mathrm{OE}$ & 1,8 & 4,0 & 5,9 & 4,1 & 1,9 & 2,2 & \\
\hline \multirow[t]{2}{*}{5} & OD & 2,0 & 4,0 & 5,9 & 3,9 & 1,9 & 2,0 & \multirow[t]{2}{*}{0} \\
\hline & $\mathrm{OE}$ & 2,0 & 4,0 & 5,9 & 3,9 & 1,9 & 2,0 & \\
\hline \multirow[t]{2}{*}{6} & OD & 1,9 & 4,0 & 5,9 & 4,0 & 1,9 & 2,1 & \multirow[t]{2}{*}{0} \\
\hline & $\mathrm{OE}$ & 1,9 & 4,0 & 5,9 & 4,0 & 1,9 & 2,1 & \\
\hline \multirow[t]{2}{*}{7} & OD & 2,8 & 4,8 & 6,6 & 3,8 & 1,8 & 1,9 & \multirow[t]{2}{*}{0,2} \\
\hline & $\mathrm{OE}$ & 2,8 & 4,9 & 6,8 & 4,0 & 1,9 & 2,1 & \\
\hline \multirow[t]{2}{*}{8} & OD & 2,0 & 4,0 & 5,8 & 3,8 & 1,8 & 2,0 & \multirow[t]{2}{*}{0,1} \\
\hline & $\mathrm{OE}$ & 1,8 & 3,9 & 5,7 & 3,9 & 1,8 & 2,1 & \\
\hline \multirow[t]{2}{*}{9} & OD & 1,9 & 3,9 & 5,9 & 4,0 & 2,0 & 2,0 & \multirow[t]{2}{*}{0} \\
\hline & $\mathrm{OE}$ & 2,0 & 3,9 & 5,9 & 3,9 & 2,0 & 1,9 & \\
\hline \multirow[t]{2}{*}{10} & OD & 2,0 & 4,0 & 5,8 & 3,8 & 1,8 & 2,0 & \multirow[t]{2}{*}{0} \\
\hline & $\mathrm{OE}$ & 2,0 & 4,0 & 5,8 & 3,8 & 1,8 & 2,0 & \\
\hline \multirow[t]{2}{*}{11} & OD & 1,8 & 3,8 & 5,8 & 4,0 & 2,0 & 2,0 & \multirow[t]{2}{*}{0,1} \\
\hline & $\mathrm{OE}$ & 2,0 & 3,9 & 5,9 & 3,9 & 2,0 & 1,9 & \\
\hline 12 & OD & 2,0 & 4,1 & 6,0 & 4,0 & 1,9 & 2,1 & 0,2 \\
\hline & $\mathrm{OE}$ & 2,2 & 4,3 & 6,2 & 4,0 & 2,1 & 1,9 & \\
\hline 13 & OD & 1,9 & 4,0 & 5,9 & 4,0 & 1,9 & 2,1 & 0 \\
\hline & $\mathrm{OE}$ & 1,9 & 4,0 & 5,9 & 4,0 & 1,9 & 2,1 & \\
\hline 14 & OD & 1,9 & 4,0 & 5,8 & 3,9 & 1,8 & 2,1 & 0,1 \\
\hline & $\mathrm{OE}$ & 1,9 & 3,8 & 5,7 & 3,8 & 1,9 & 1,9 & \\
\hline 15 & OD & 2,0 & 4,1 & 6,1 & 4,1 & 2,0 & 2,1 & 0,1 \\
\hline & $\mathrm{OE}$ & 1,9 & 4,0 & 6,0 & 4,1 & 2,0 & 2,1 & \\
\hline 16 & OD & 1,9 & 4,0 & 5,9 & 4,0 & 1,9 & 2,1 & 0 \\
\hline & $\mathrm{OE}$ & 2,0 & 4,0 & 5,9 & 3,9 & 1,9 & 2,0 & \\
\hline 17 & OD & 1,9 & 4,0 & 5,9 & 4,0 & 1,9 & 2,1 & 0,1 \\
\hline & $\mathrm{OE}$ & 2,0 & 4,0 & 5,8 & 3,8 & 1,8 & 2,0 & \\
\hline 18 & OD & 2,0 & 4,0 & 5,9 & 3,9 & 1,9 & 2,0 & 0,1 \\
\hline & $\mathrm{OE}$ & 2,0 & 4,0 & 5,8 & 3,8 & 1,8 & 2,0 & \\
\hline 19 & OD & 1,9 & 3,9 & 5,9 & 4,0 & 2,0 & 2,0 & 0,1 \\
\hline & $\mathrm{OE}$ & 1,9 & 4,0 & 5,8 & 3,9 & 1,8 & 2,1 & \\
\hline 20 & OD & 1,9 & 3,9 & 5,7 & 3,8 & 1,8 & 2,0 & 0 \\
\hline & $\mathrm{OE}$ & 1,9 & 3,8 & 5,7 & 3,8 & 1,9 & 1,9 & \\
\hline 21 & OD & 1,9 & 4,0 & 6,0 & 4,1 & 2,0 & 2,1 & 0 \\
\hline & $\mathrm{OE}$ & 2,0 & 3,9 & 6,0 & 4,0 & 2,1 & 1,9 & \\
\hline 22 & OD & 2,3 & 4,4 & 6,4 & 4,1 & 2,0 & 2,1 & 0,2 \\
\hline & $\mathrm{OE}$ & 2,2 & 4,2 & 6,2 & 4,0 & 1,9 & 2,0 & \\
\hline
\end{tabular}

ANEXO 13 - Resultados do PEATE no GC (latências em ms)

$$
\begin{array}{|l|l|l|l|l|l|l|}
\hline \mathrm{N}^{\mathrm{o}} & \text { Orelha } & \mathrm{I} & \mathrm{III} & \mathrm{V} & \mathrm{I}-\mathrm{V} & \mathrm{III}-\mathrm{V} \\
\hline
\end{array}
$$

III-V I-III 


\begin{tabular}{|c|c|c|c|c|c|c|c|c|}
\hline \multirow[t]{2}{*}{1} & OD & 2,0 & 4,1 & 6,1 & 4,1 & 2,0 & 2,1 & \multirow[t]{2}{*}{0} \\
\hline & $\mathrm{OE}$ & 2,0 & 4,1 & 6,1 & 4,1 & 2,0 & 2,1 & \\
\hline \multirow[t]{2}{*}{2} & OD & 2,0 & 4,0 & 5,9 & 3,9 & 1,9 & 2,0 & \multirow[t]{2}{*}{0} \\
\hline & $\mathrm{OE}$ & 2,0 & 4,0 & 5,9 & 3,9 & 1,9 & 2,0 & \\
\hline \multirow[t]{2}{*}{3} & OD & 1,9 & 4,1 & 6,0 & 4,1 & 1,9 & 2,2 & \multirow[t]{2}{*}{0,1} \\
\hline & $\mathrm{OE}$ & 2,0 & 4,1 & 6,1 & 4,1 & 2,0 & 2,1 & \\
\hline \multirow[t]{2}{*}{4} & OD & 1,9 & 4,0 & 5,8 & 3,9 & 1,8 & 2,1 & \multirow[t]{2}{*}{0} \\
\hline & $\mathrm{OE}$ & 1,8 & 3,9 & 5,9 & 4,0 & 2,0 & 2,0 & \\
\hline \multirow[t]{2}{*}{5} & OD & 2,0 & 3,9 & 5,8 & 3,8 & 1,9 & 1,9 & \multirow[t]{2}{*}{0} \\
\hline & $\mathrm{OE}$ & 2,0 & 3,9 & 5,8 & 3,8 & 1,9 & 1,9 & \\
\hline \multirow[t]{2}{*}{6} & OD & 1,9 & 4,1 & 6,0 & 4,1 & 1,9 & 2,2 & \multirow[t]{2}{*}{0,1} \\
\hline & $\mathrm{OE}$ & 1,9 & 4,0 & 5,9 & 4,0 & 1,9 & 2,1 & \\
\hline \multirow[t]{2}{*}{7} & OD & 1,8 & 3,8 & 5,8 & 4,0 & 2,0 & 2,0 & \multirow[t]{2}{*}{0} \\
\hline & $\mathrm{OE}$ & 2,0 & 3,9 & 5,9 & 3,9 & 2,0 & 1,9 & \\
\hline \multirow[t]{2}{*}{8} & OD & 1,8 & 3,9 & 5,8 & 4,0 & 1,9 & 2,1 & \multirow[t]{2}{*}{0} \\
\hline & $\mathrm{OE}$ & 1,9 & 3,9 & 5,8 & 3,9 & 1,9 & 2,0 & \\
\hline \multirow[t]{2}{*}{9} & OD & 1,9 & 4,1 & 6,0 & 4,1 & 1,9 & 2,2 & \multirow[t]{2}{*}{0} \\
\hline & $\mathrm{OE}$ & 1,9 & 4,1 & 6,0 & 4,1 & 1,9 & 2,2 & \\
\hline \multirow[t]{2}{*}{10} & OD & 2,0 & 4,0 & 5,9 & 4,0 & 1,9 & 2,0 & \multirow[t]{2}{*}{0,1} \\
\hline & $\mathrm{OE}$ & 2,0 & 3,8 & 5,8 & 3,8 & 2,0 & 1,8 & \\
\hline \multirow[t]{2}{*}{11} & OD & 2,0 & 4,0 & 5,9 & 3,9 & 1,9 & 2,0 & \multirow[t]{2}{*}{0,1} \\
\hline & $\mathrm{OE}$ & 1,8 & 3,8 & 5,8 & 4,0 & 2,0 & 2,0 & \\
\hline \multirow[t]{2}{*}{12} & OD & 2,0 & 4,0 & 5,9 & 3,9 & 1,9 & 2,0 & 0 \\
\hline & $\mathrm{OE}$ & 2,0 & 4,0 & 5,9 & 3,9 & 1,9 & 2,0 & \\
\hline 13 & OD & 1,9 & 3,9 & 5,8 & 3,9 & 1,9 & 2,0 & 0 \\
\hline & $\mathrm{OE}$ & 1,8 & 3,9 & 5,8 & 4,0 & 1,9 & 2,1 & \\
\hline 14 & OD & 1,9 & 4,1 & 6,1 & 4,2 & 2,0 & 2,1 & 0 \\
\hline & $\mathrm{OE}$ & 1,9 & 4,0 & 6,1 & 4,2 & 2,1 & 2,1 & \\
\hline 15 & OD & 2,0 & 3,9 & 5,9 & 3,9 & 2,0 & 1,9 & 0 \\
\hline & $\mathrm{OE}$ & 2,0 & 3,9 & 5,9 & 3,9 & 2,0 & 1,9 & \\
\hline 16 & OD & 1,8 & 3,8 & 5,8 & 4,0 & 2,0 & 2,0 & 0 \\
\hline & $\mathrm{OE}$ & 1,8 & 3,8 & 5,8 & 4,0 & 2,0 & 2,0 & \\
\hline 17 & OD & 1,9 & 4,1 & 6,0 & 4,1 & 1,9 & 2,2 & 0,1 \\
\hline & $\mathrm{OE}$ & 1,9 & 4,1 & 6,1 & 4,2 & 2,0 & 2,2 & \\
\hline 18 & OD & 2,0 & 3,9 & 5,8 & 3,8 & 1,9 & 1,9 & 0 \\
\hline & $\mathrm{OE}$ & 2,0 & 4,0 & 5,8 & 3,8 & 1,8 & 2,0 & \\
\hline 19 & OD & 1,9 & 4,0 & 6,0 & 4,1 & 2,0 & 2,1 & 0,1 \\
\hline & $\mathrm{OE}$ & 1,8 & 4,0 & 5,9 & 4,0 & 1,9 & 2,1 & \\
\hline 20 & OD & 2,0 & 4,0 & 5,9 & 3,9 & 1,9 & 2,0 & 0 \\
\hline & $\mathrm{OE}$ & 1,9 & 3,9 & 5,9 & 4,0 & 2,0 & 2,0 & \\
\hline 21 & OD & 1,9 & 3,8 & 5,8 & 3,9 & 2,0 & 1,9 & 0,1 \\
\hline & $\mathrm{OE}$ & 1,9 & 3,9 & 5,9 & 4,0 & 2,0 & 2,0 & \\
\hline 22 & OD & 1,9 & 3,9 & 5,8 & 3,9 & 1,9 & 2,0 & 0 \\
\hline & $\mathrm{OE}$ & 1,9 & 3,8 & 5,8 & 3,9 & 2,0 & 1,9 & \\
\hline
\end{tabular}

